Supporting Information for

\title{
Sublyratins A-O, Labdane-Type Diterpenoids from Croton sublyratus
}

Jing-Jing Qi ${ }^{\dagger, \dagger}$, Jun-Su Zhou ${ }^{\dagger}$, Yan Zhang ${ }^{\dagger}$, Yao-Yue Fan ${ }^{\dagger}$, Bin Zhou ${ }^{\dagger}$, Hong-Chun Liu, ${ }^{\dagger}$ Jin-Xin Zhao ${ }^{*, \dagger}$, and Jian-Min Yue ${ }^{*, \dagger, \dagger}$

${ }^{\dagger}$ State Key Laboratory of Drug Research, Shanghai Institute of Materia Medica, Chinese Academy of Sciences, 555 Zuchongzhi Road, Shanghai 201203, People's Republic of China

${ }^{\star}$ School of Chinese Materia Medica, Nanjing University of Chinese Medicine, 138 Xianlin Road, Nanjing 210023, People's Republic of China

* Corresponding authors

E-mail addresses: jxzhao@ simm.ac.cn,jmyue@ simm.ac.cn; Tel.: +86 2150806718. 


\section{Contents}

Figure S1. Selected ${ }^{1} \mathrm{H}-{ }^{1} \mathrm{H}$ COSY (bold bonds), HMBC correlations (A), and NOESY

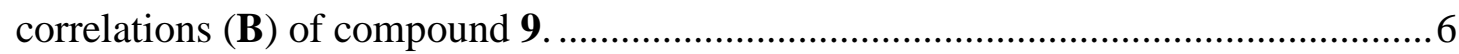

Figure S2 ECD spectrum of compound 9. .........................................................

Figure S3. Selected ${ }^{1} \mathrm{H}-{ }^{1} \mathrm{H}$ COSY (bold bonds), HMBC correlations (A), and NOESY

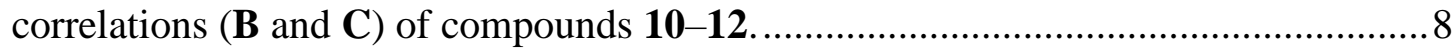

Figure S4. Selected ${ }^{1} \mathrm{H}-{ }^{1} \mathrm{H}$ COSY (bold bonds), HMBC correlations (A), and NOESY correlations (B) of compound $\mathbf{1 3}$.

Figure S5. Selected ${ }^{1} \mathrm{H}-{ }^{1} \mathrm{H}$ COSY (bold bonds), HMBC correlations (A), and NOESY correlations (B and $\mathbf{C}$ ) of compounds $\mathbf{1 4}$ and $\mathbf{1 5}$..... 10

Figure S6 ECD spectrum of compounds 14 and 15. 11

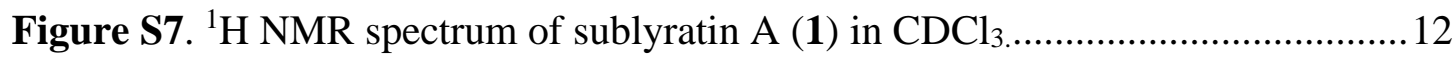

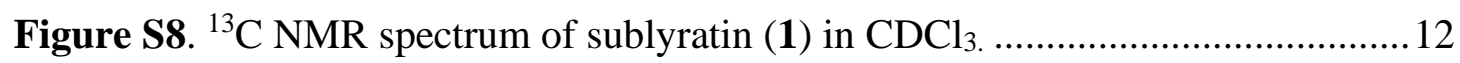

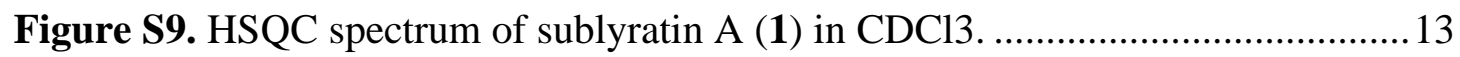

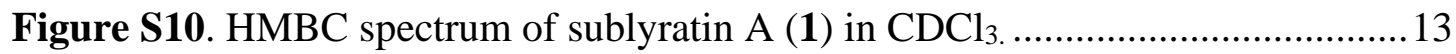

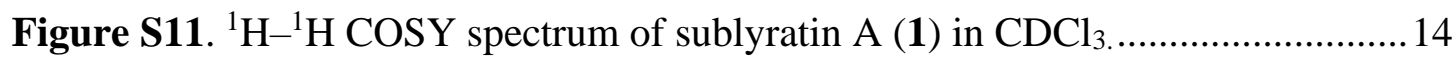

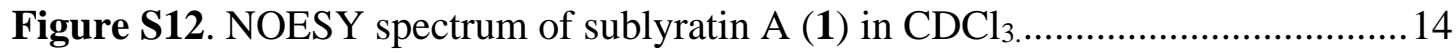

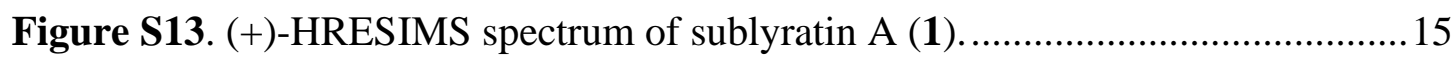

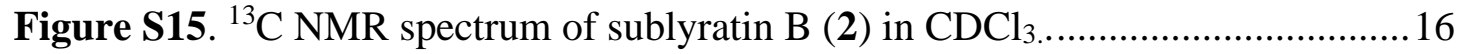

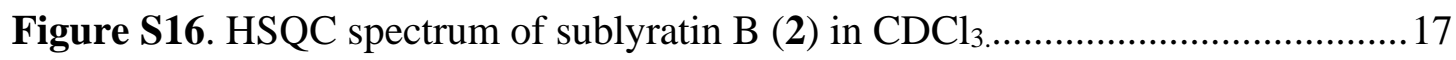

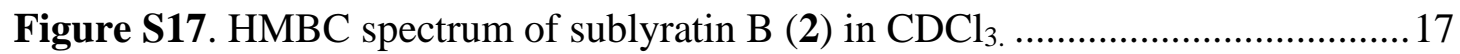

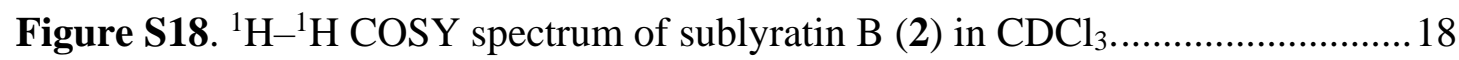

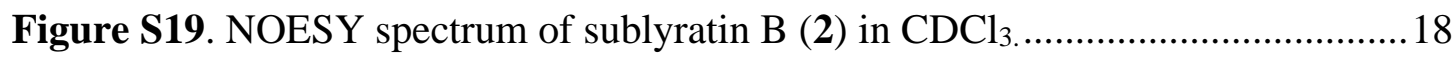

Figure S20. (+)-HRESIMS spectrum of sublyratin B (2), .....................................19

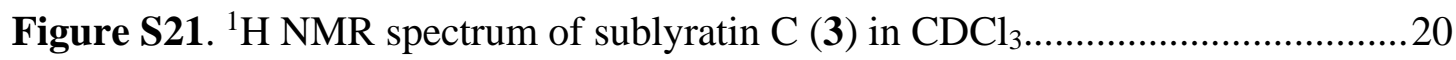

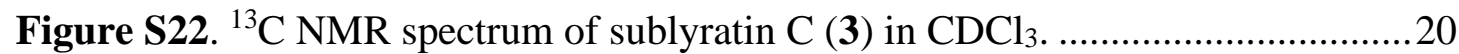

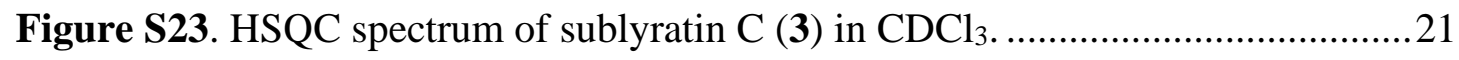

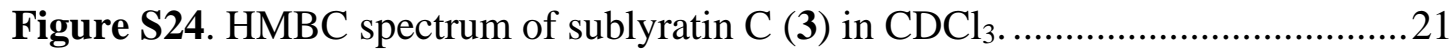

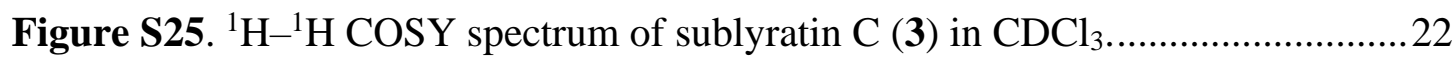




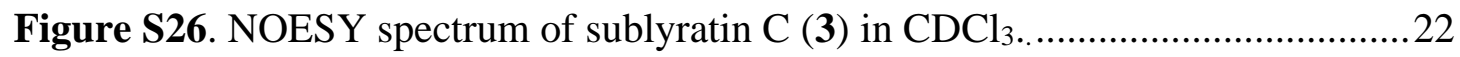

Figure S27. (+)-HRESIMS spectrum of sublyratin C (3) ....................................23

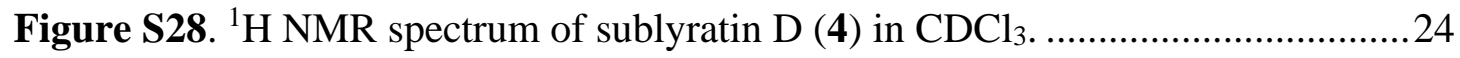

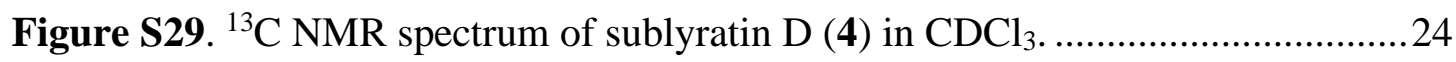

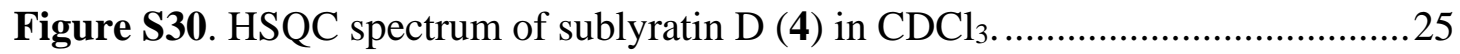

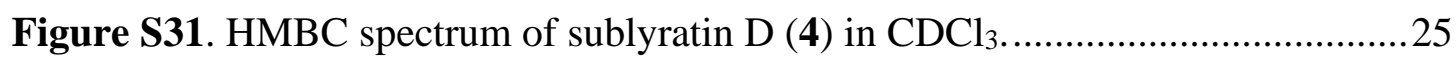

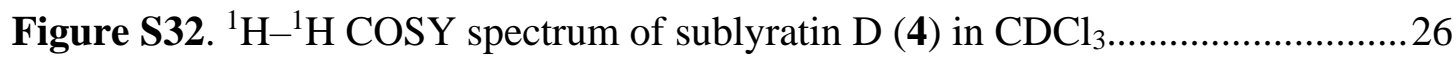

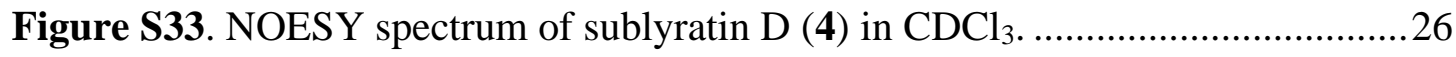

Figure S34. (+)-HRESIMS spectrum of sublyratin D (4).....................................2

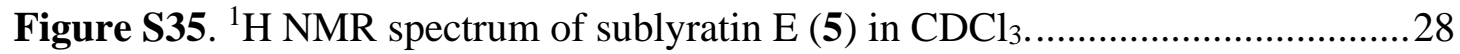

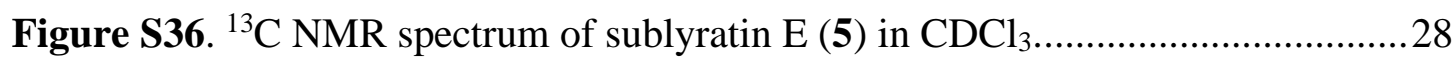

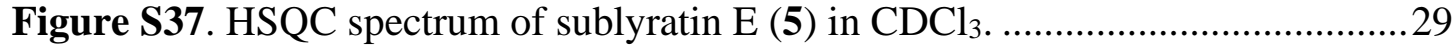

Figure S38. HMBC spectrum of sublyratin E (5) in $\mathrm{CDCl}_{3}$................................29

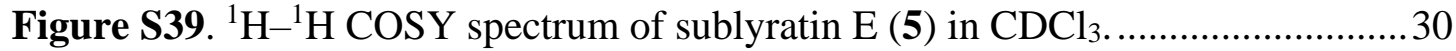

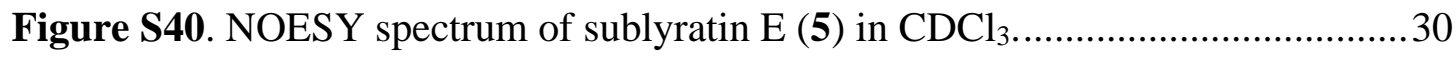

Figure S41. (+)-HRESIMS spectrum of sublyratin E (5)...................................... 31

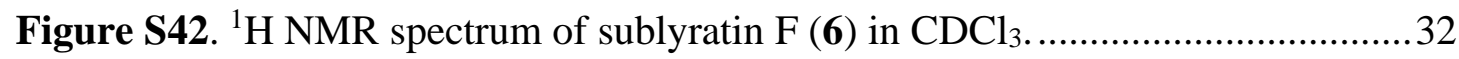

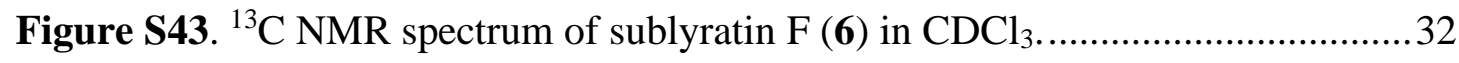

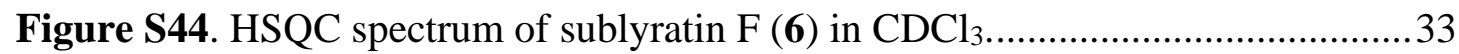

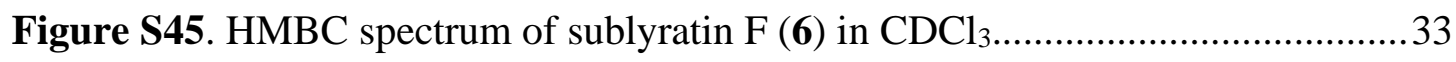

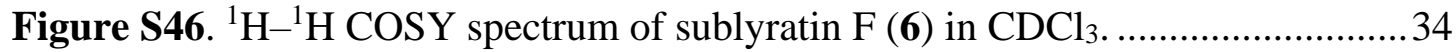

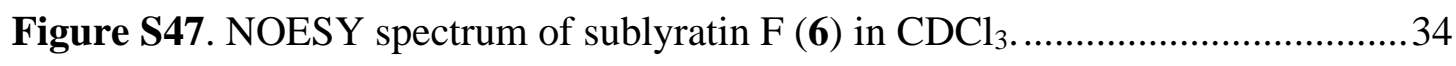

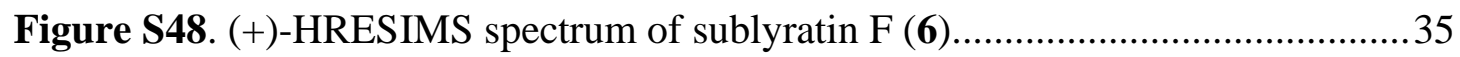

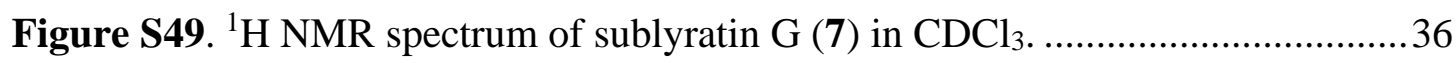

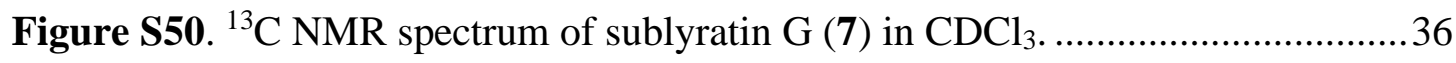

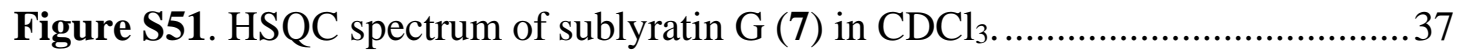

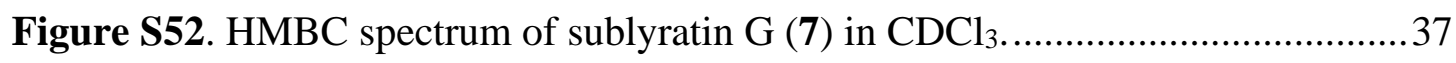

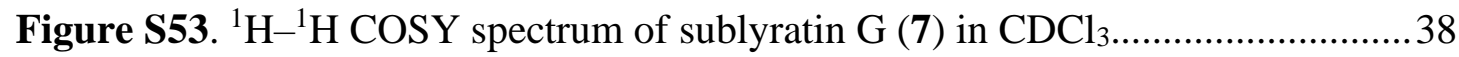

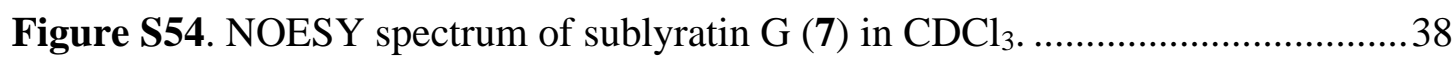

Figure S55. (+)-HRESIMS spectrum of sublyratin G (7), ....................................... 
Figure S56. ${ }^{1} \mathrm{H}$ NMR spectrum of sublyratin $\mathrm{H}(\mathbf{8})$ in $\mathrm{CDCl}_{3} \ldots \ldots \ldots \ldots \ldots \ldots \ldots \ldots \ldots . . . . . . . . . . . . . . . . .40$

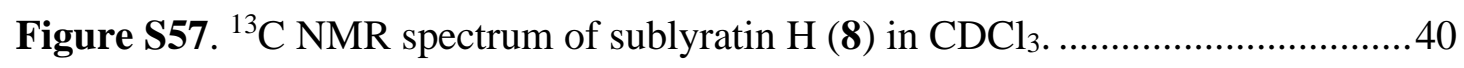

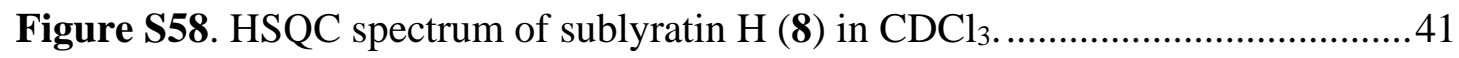

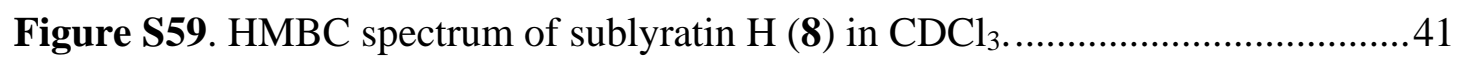

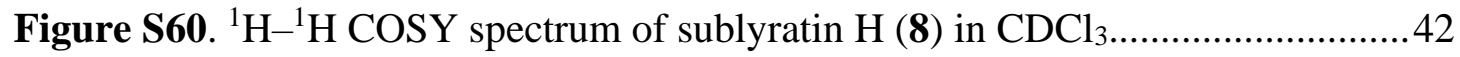

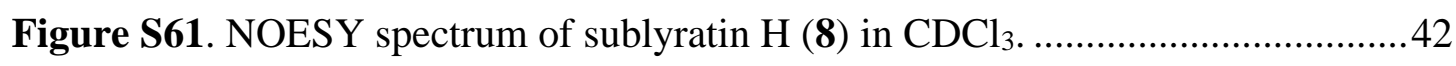

Figure S62. (+)-HRESIMS spectrum of sublyratin H (8), .....................................43

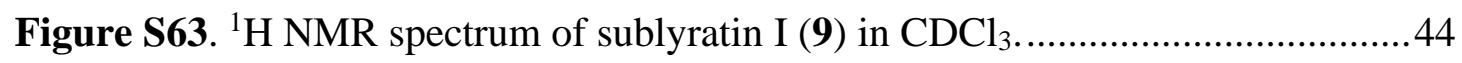

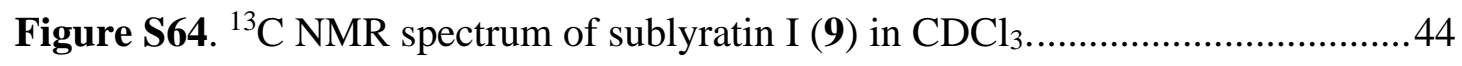

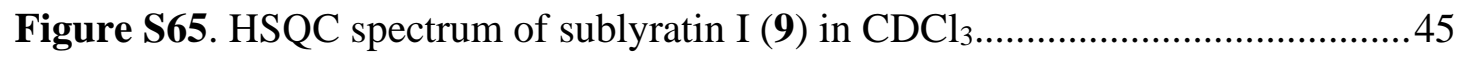

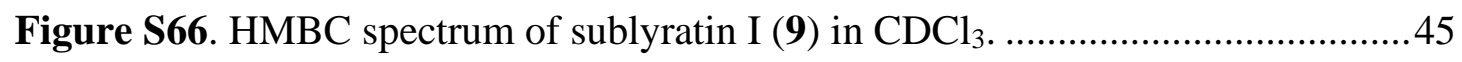

Figure S67. ${ }^{1} \mathrm{H}-{ }^{1} \mathrm{H}$ COSY spectrum of sublyratin I (9) in $\mathrm{CDCl}_{3} \ldots \ldots \ldots \ldots \ldots \ldots \ldots . . . . . . . . . . . . . .46$

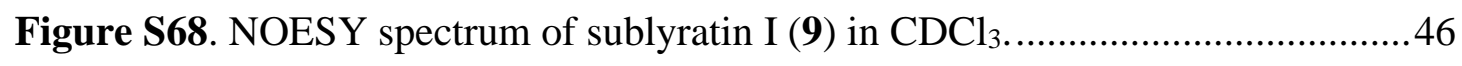

Figure S69. (+)-HRESIMS spectrum of sublyratin I (9). ....................................47

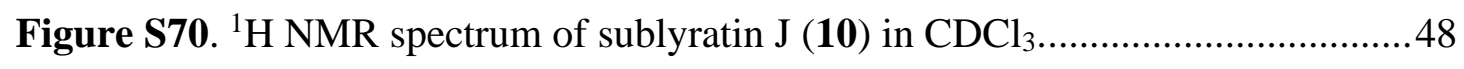

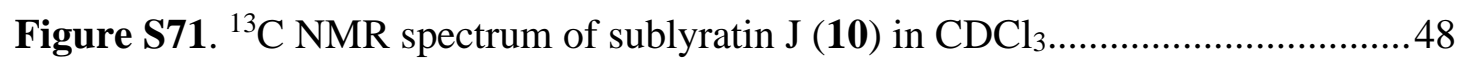

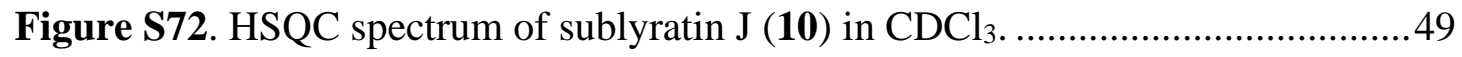

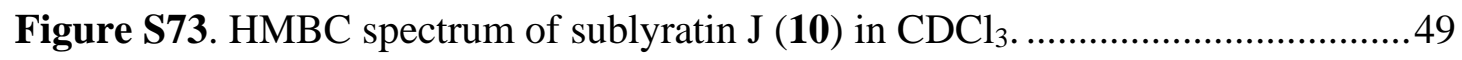

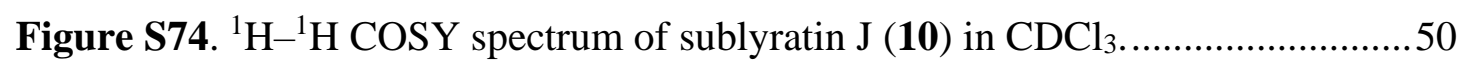

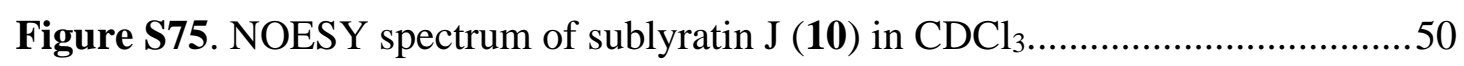

Figure S76. (+)-HRESIMS spectrum of sublyratin J (10) ....................................51

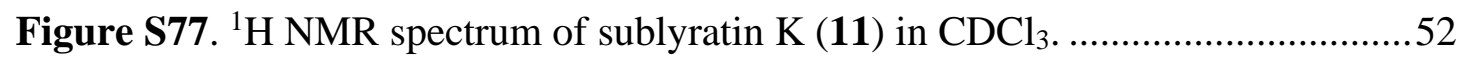

Figure S78. ${ }^{13} \mathrm{C}$ NMR spectrum of sublyratin $\mathrm{K}(\mathbf{1 1})$ in $\mathrm{CDCl}_{3} \ldots \ldots \ldots \ldots \ldots \ldots \ldots \ldots \ldots . . .52$

Figure S79. HSQC spectrum of sublyratin $\mathrm{K}(\mathbf{1 1})$ in $\mathrm{CDCl}_{3} \ldots \ldots \ldots \ldots \ldots \ldots \ldots \ldots \ldots \ldots . . . . . . . \ldots 3$

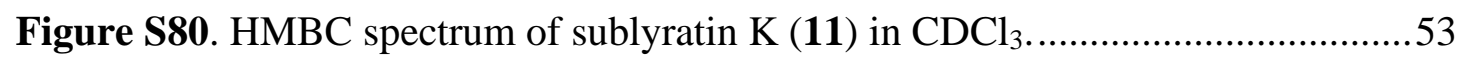

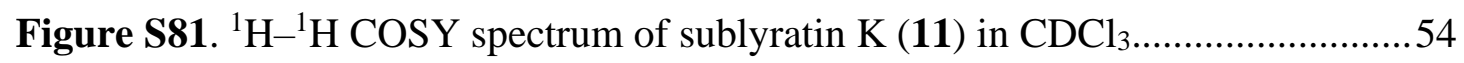

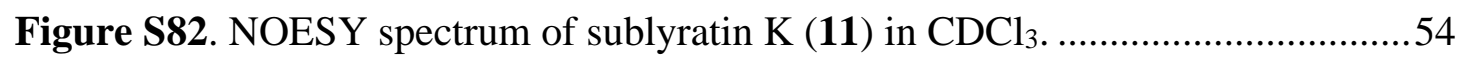

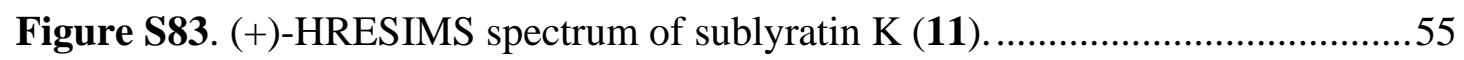

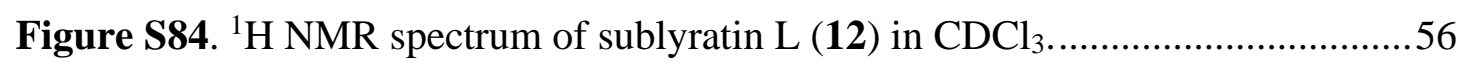

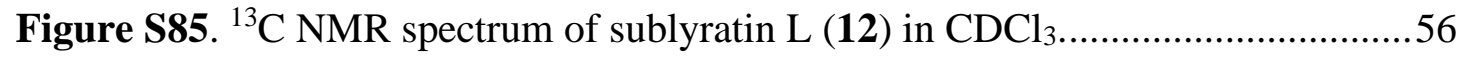




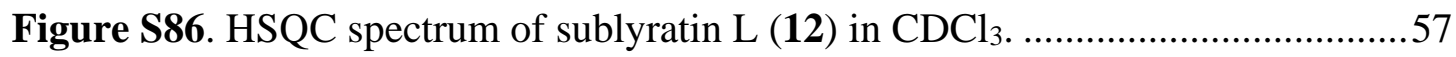

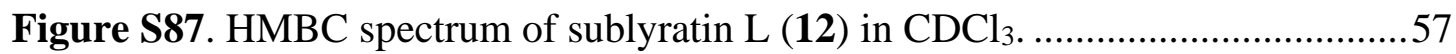

Figure S88. ${ }^{1} \mathrm{H}-{ }^{1} \mathrm{H}$ COSY spectrum of sublyratin $\mathrm{L}(\mathbf{1 2})$ in $\mathrm{CDCl}_{3} \ldots \ldots \ldots \ldots \ldots \ldots \ldots . . .58$

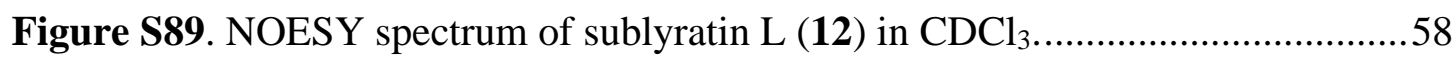

Figure S90. (+)-HRESIMS spectrum of sublyratin L (12) _..................................59

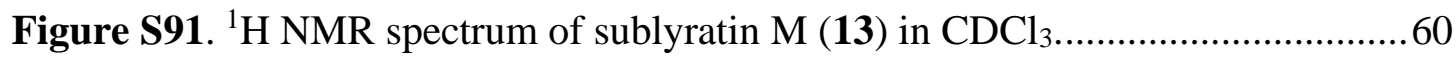

Figure S92. ${ }^{13} \mathrm{C}$ NMR spectrum of sublyratin $\mathrm{M}(\mathbf{1 3})$ in $\mathrm{CDCl}_{3} \ldots \ldots \ldots \ldots \ldots \ldots \ldots \ldots . . . . . . . . . . . . . . . . .60$

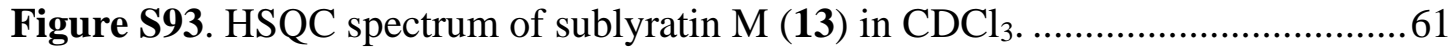

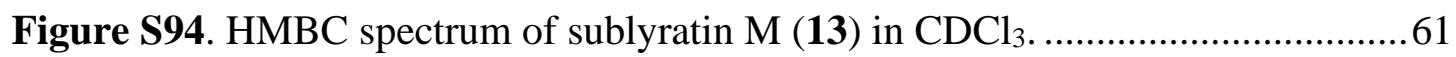

Figure S95. ${ }^{1} \mathrm{H}-{ }^{1} \mathrm{H}$ COSY spectrum of sublyratin $\mathrm{M}(\mathbf{1 3})$ in $\mathrm{CDCl}_{3} \ldots \ldots \ldots \ldots \ldots \ldots \ldots . . . . . . . . . . . .62$

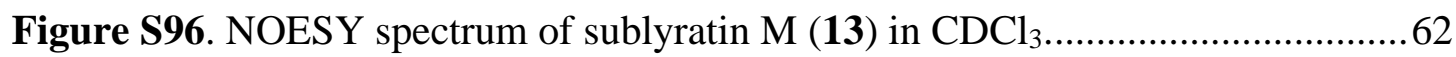

Figure S97. (+)-HRESIMS spectrum of sublyratin M (13)...................................63

Figure S98. ${ }^{1} \mathrm{H}$ NMR spectrum of sublyratin $\mathrm{N}(\mathbf{1 4})$ in $\mathrm{CDCl}_{3}$.............................64

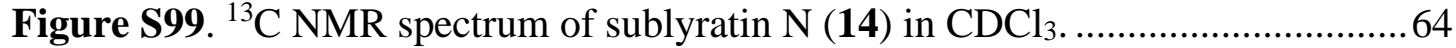

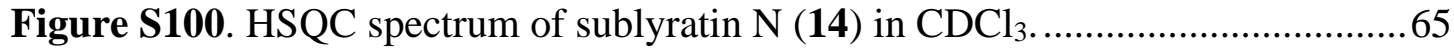

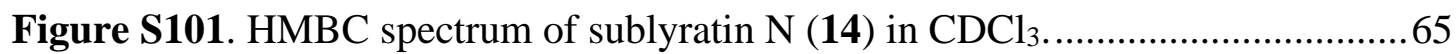

Figure S102. ${ }^{1} \mathrm{H}-{ }^{1} \mathrm{H}$ COSY spectrum of sublyratin $\mathrm{N}(\mathbf{1 4})$ in $\mathrm{CDCl}_{3} \ldots \ldots \ldots \ldots \ldots \ldots \ldots . . . . . . . . . . .66$

Figure S103. NOESY spectrum of sublyratin N (14) in $\mathrm{CDCl}_{3} \ldots \ldots \ldots \ldots \ldots \ldots \ldots \ldots \ldots . . . . . . . . . . . . . . .66$

Figure S104. (+)-HRESIMS spectrum of sublyratin N (14) _................................67

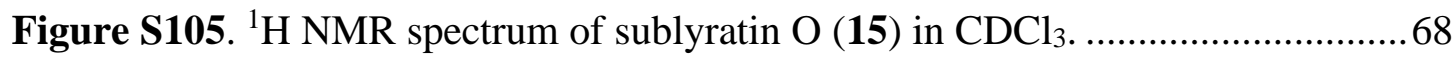

Figure S106. ${ }^{13} \mathrm{C}$ NMR spectrum of sublyratin $\mathrm{O}(\mathbf{1 5})$ in $\mathrm{CDCl}_{3} \ldots \ldots \ldots \ldots \ldots \ldots \ldots \ldots . . . . . . . . . . . . . . . .68$

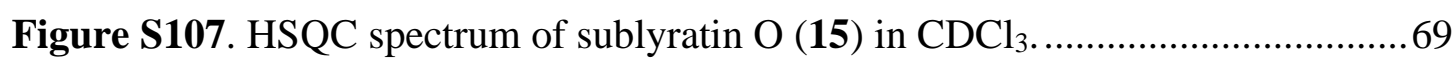

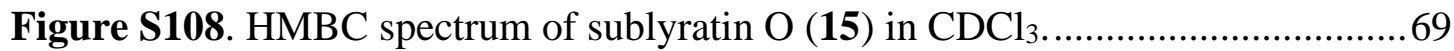

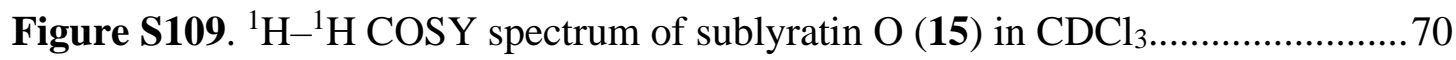

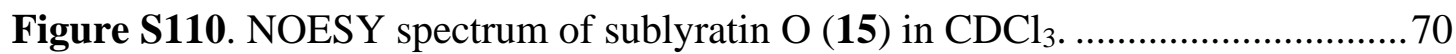

Figure S111. (-)-HRESIMS spectrum of sublyratin O (15) ….............................. 

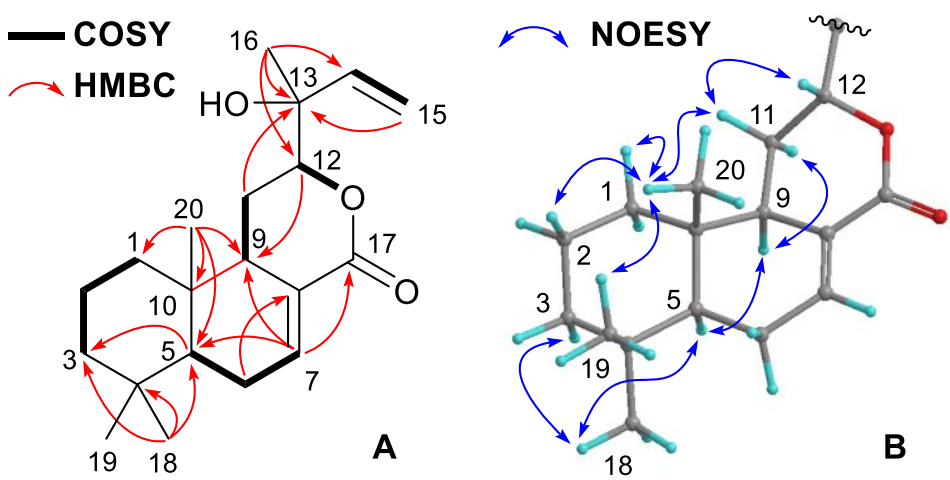

Figure S1. Selected ${ }^{1} \mathrm{H}-{ }^{1} \mathrm{H}$ COSY (bold bonds), HMBC correlations (A), and NOESY correlations (B) of compound 9. 

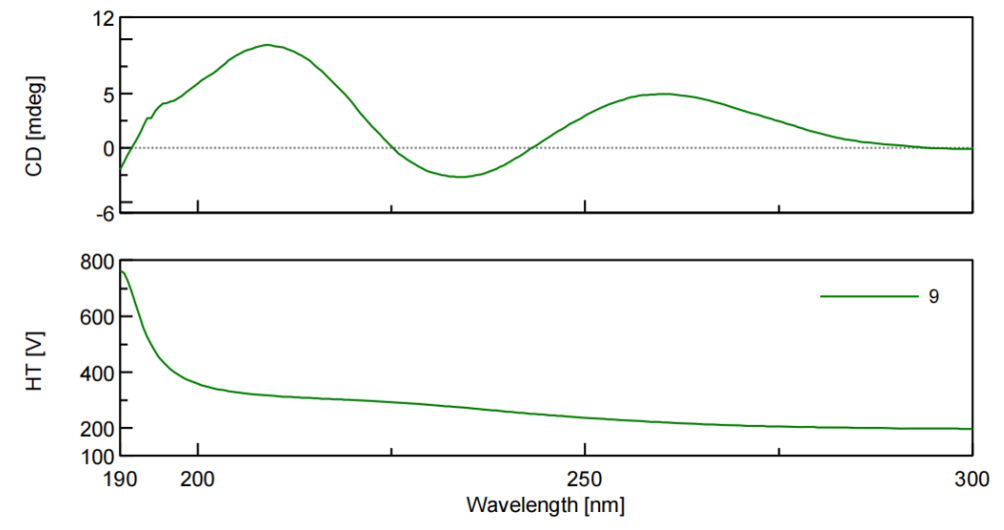

Figure S2 ECD spectrum of compound 9. 

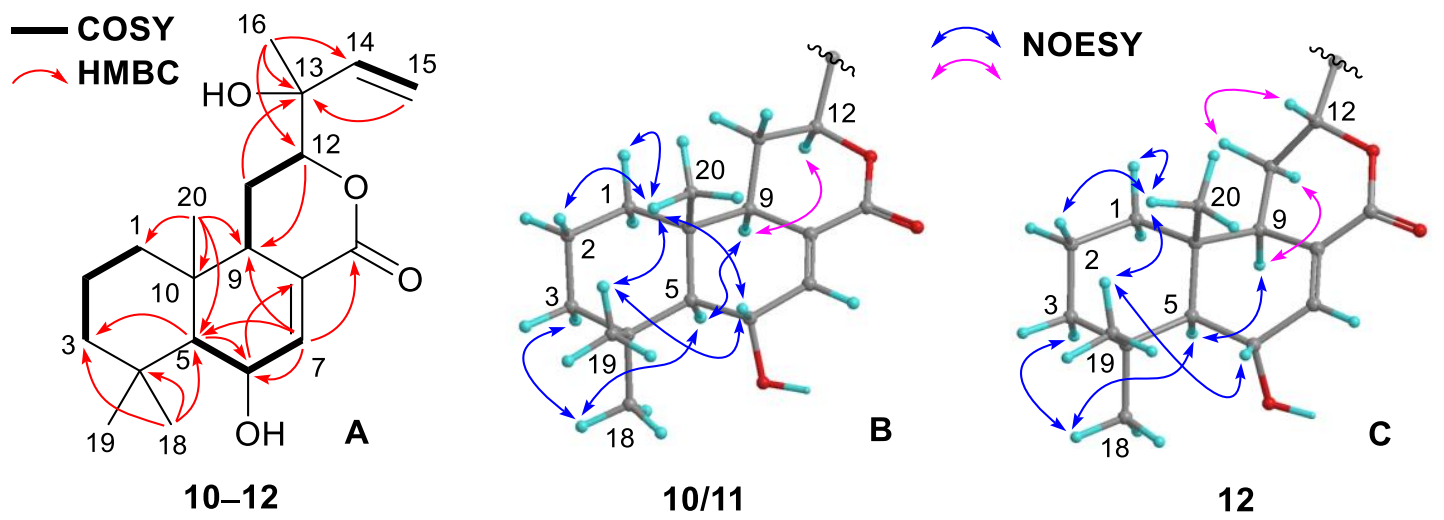

Figure S3. Selected ${ }^{1} \mathrm{H}-{ }^{1} \mathrm{H}$ COSY (bold bonds), HMBC correlations (A), and NOESY correlations (B and $\mathbf{C})$ of compounds 10-12. 

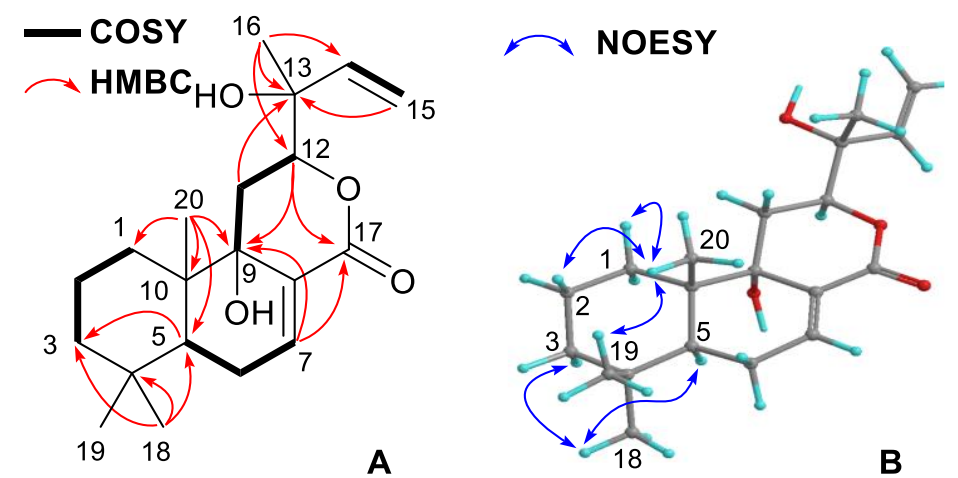

Figure S4. Selected ${ }^{1} \mathrm{H}-{ }^{1} \mathrm{H}$ COSY (bold bonds), HMBC correlations (A), and NOESY correlations (B) of compound $\mathbf{1 3 .}$ 

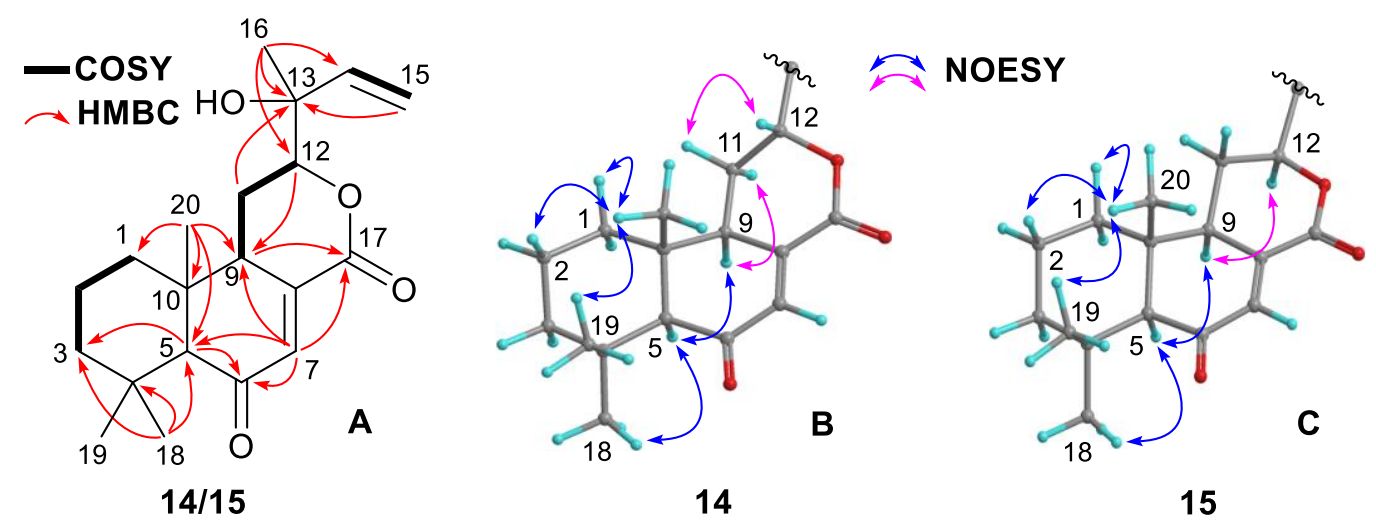

Figure S5. Selected ${ }^{1} \mathrm{H}-{ }^{1} \mathrm{H}$ COSY (bold bonds), HMBC correlations (A), and NOESY correlations (B and C) of compounds $\mathbf{1 4}$ and $\mathbf{1 5 .}$ 

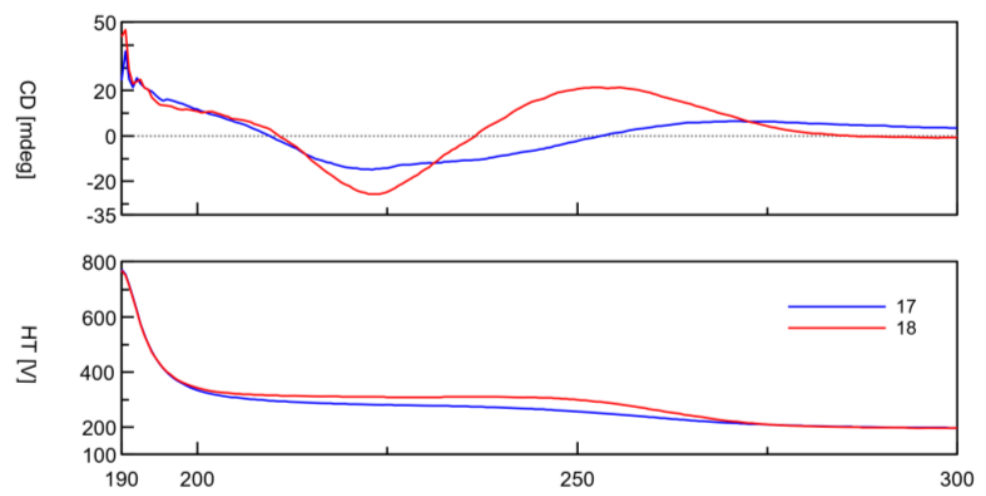

Figure S6 ECD spectrum of compounds 14 and 15. 
Figure S7. ${ }^{1} \mathrm{H}$ NMR spectrum of sublyratin $\mathrm{A}(\mathbf{1})$ in $\mathrm{CDCl}_{3}$.

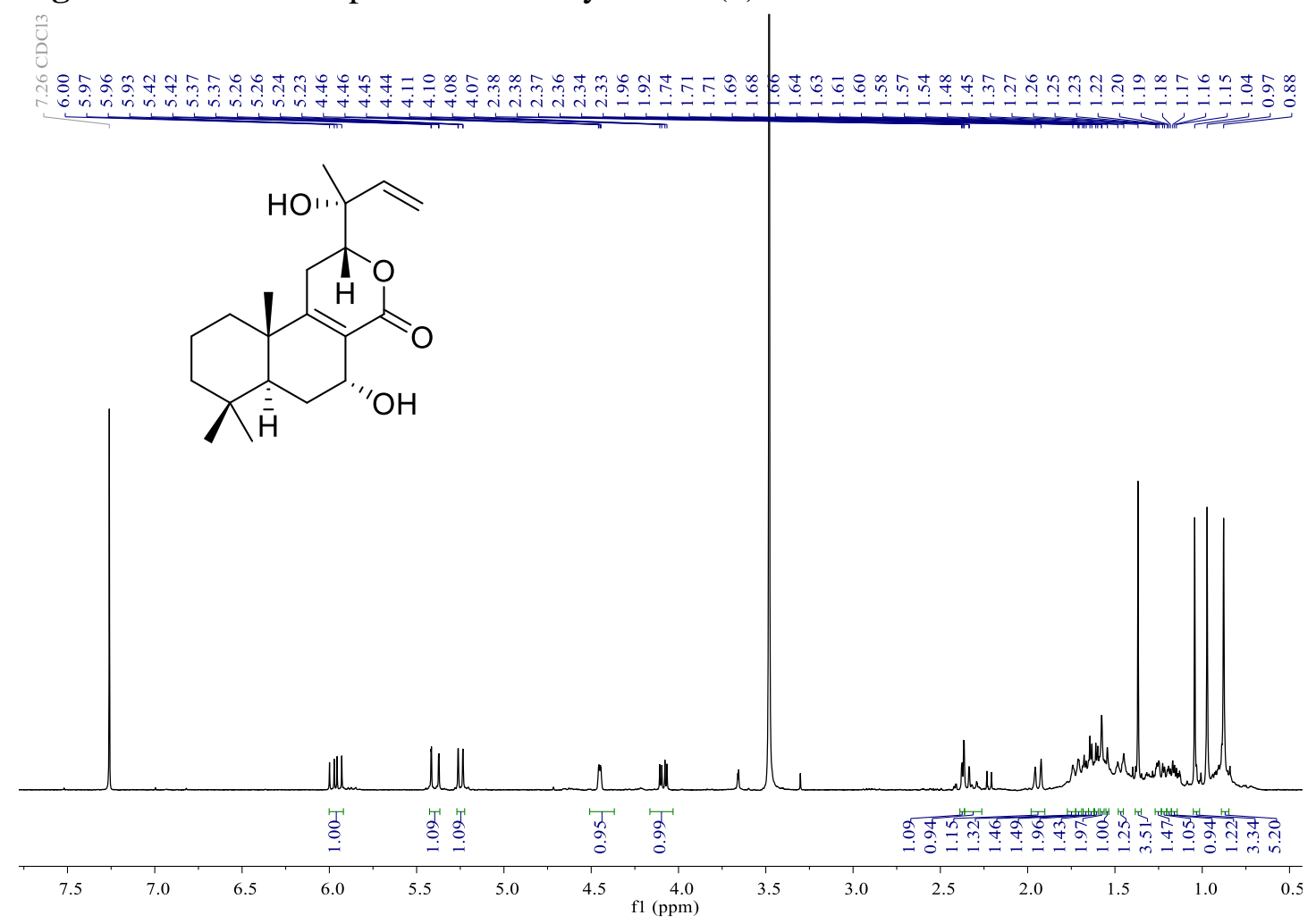

Figure S8. ${ }^{13} \mathrm{C}$ NMR spectrum of sublyratin (1) in $\mathrm{CDCl}_{3}$.

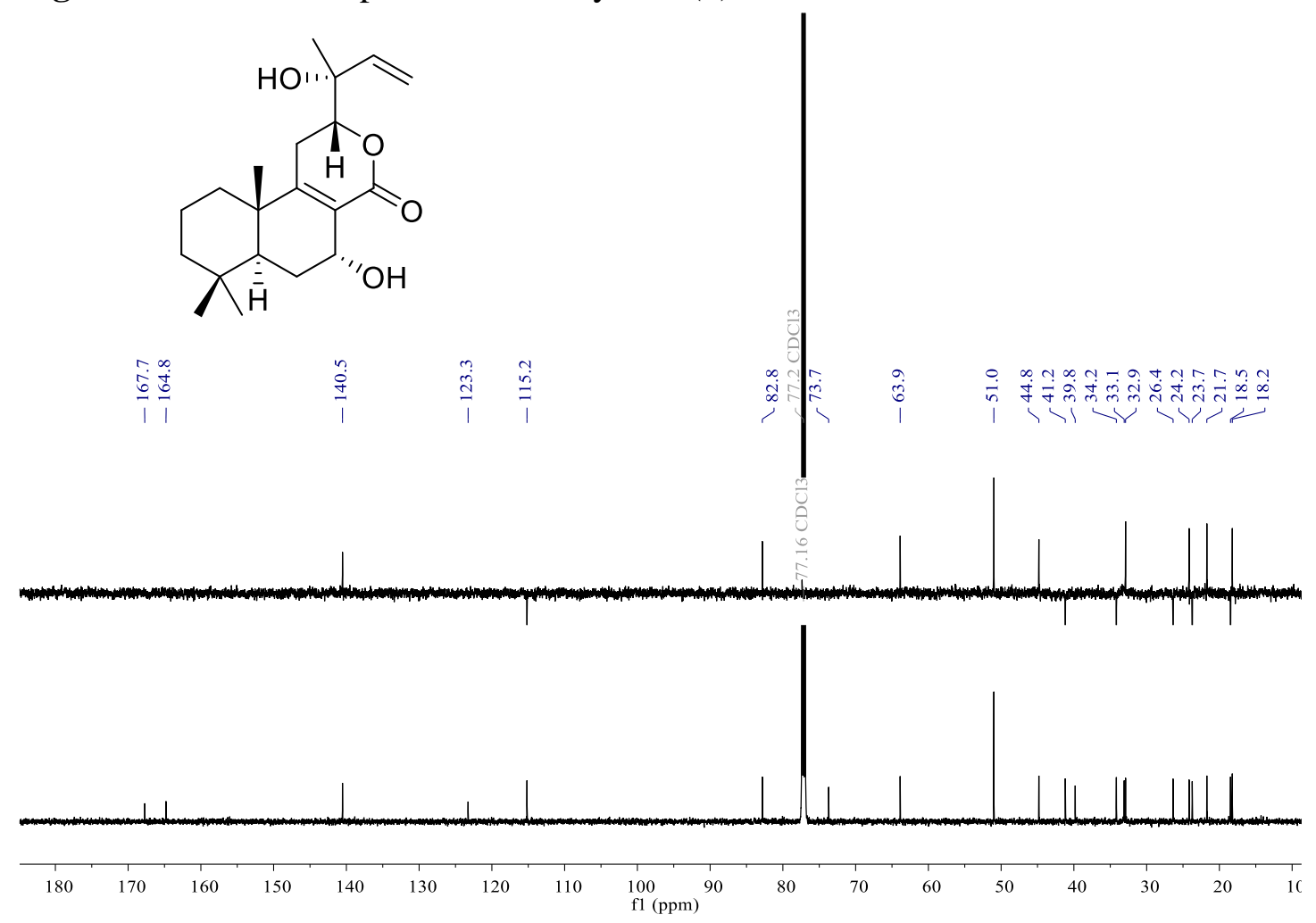


Figure S9. HSQC spectrum of sublyratin A (1) in CDCl3.

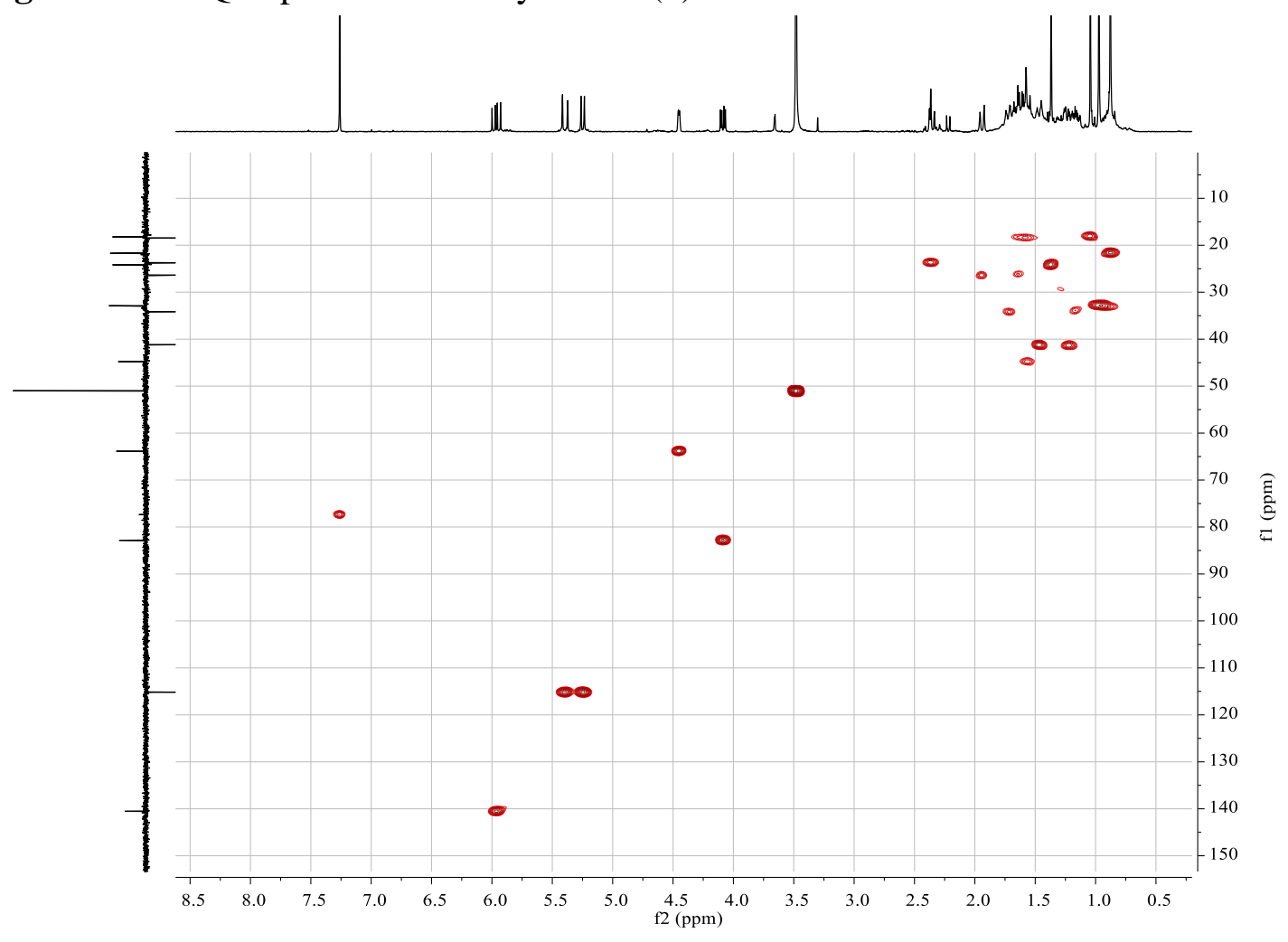

Figure S10. HMBC spectrum of sublyratin A (1) in $\mathrm{CDCl}_{3}$.

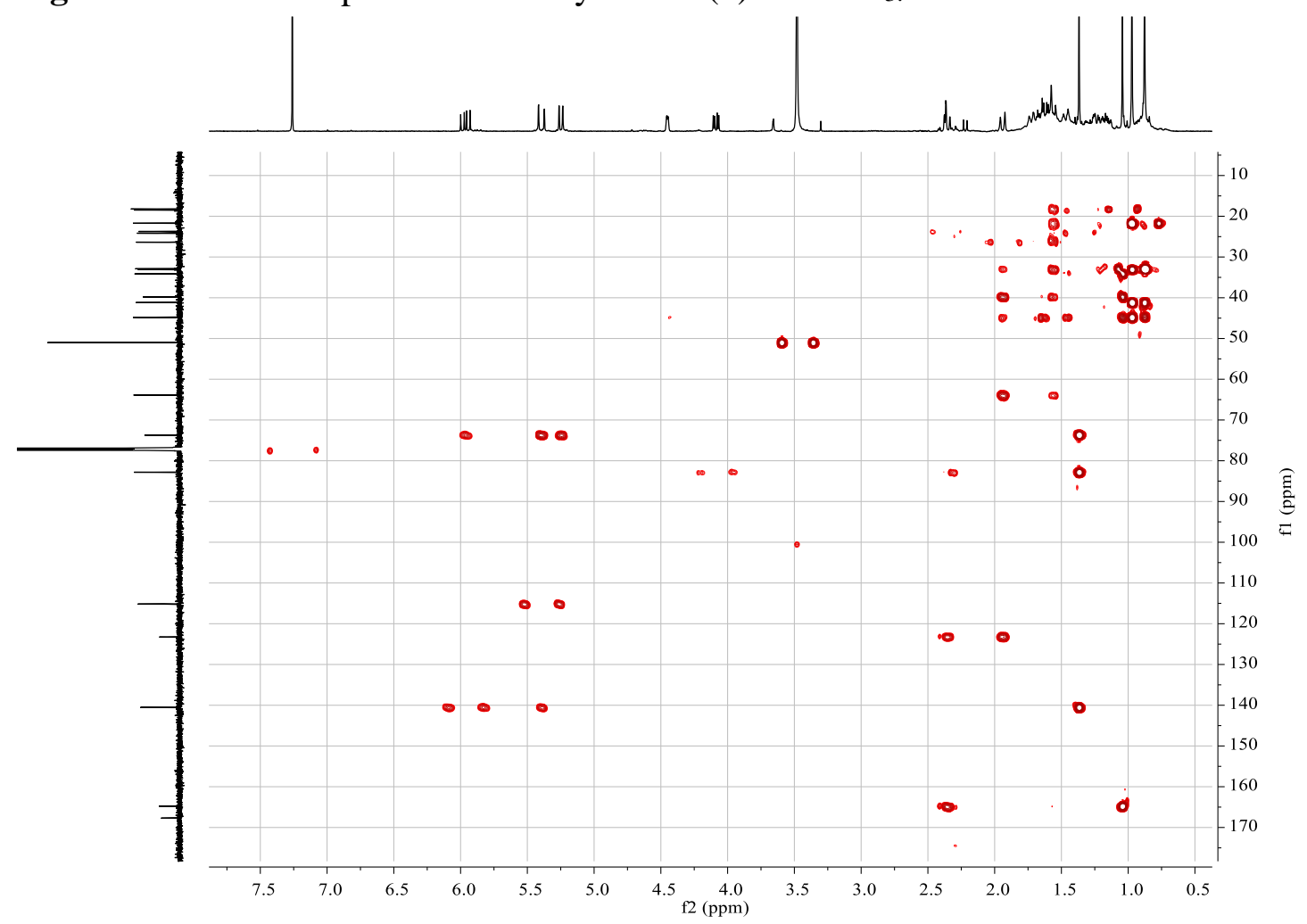


Figure S11. ${ }^{1} \mathrm{H}-{ }^{1} \mathrm{H}$ COSY spectrum of sublyratin A (1) in $\mathrm{CDCl}_{3}$.

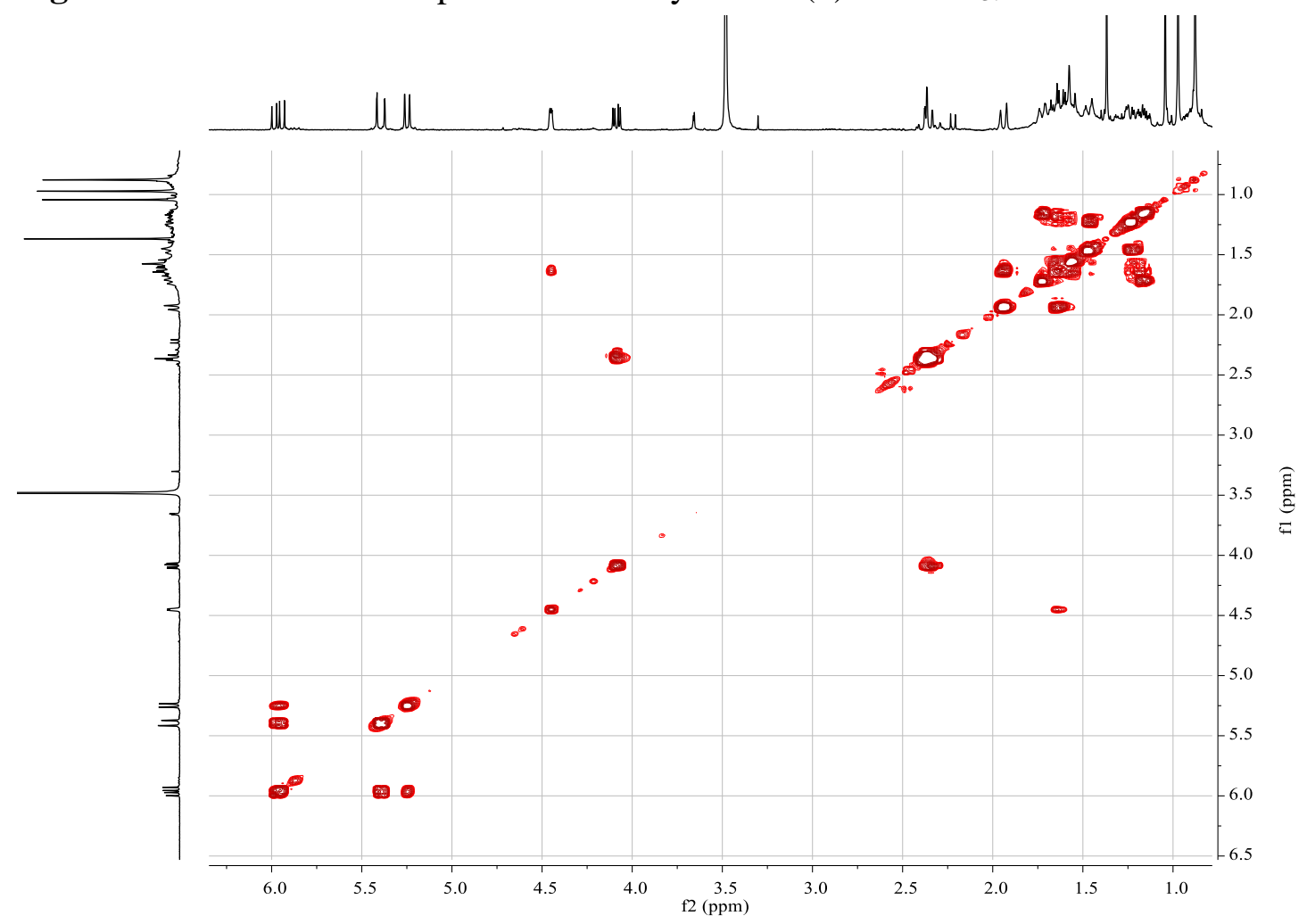

Figure S12. NOESY spectrum of sublyratin $\mathrm{A}(1)$ in $\mathrm{CDCl}_{3}$.

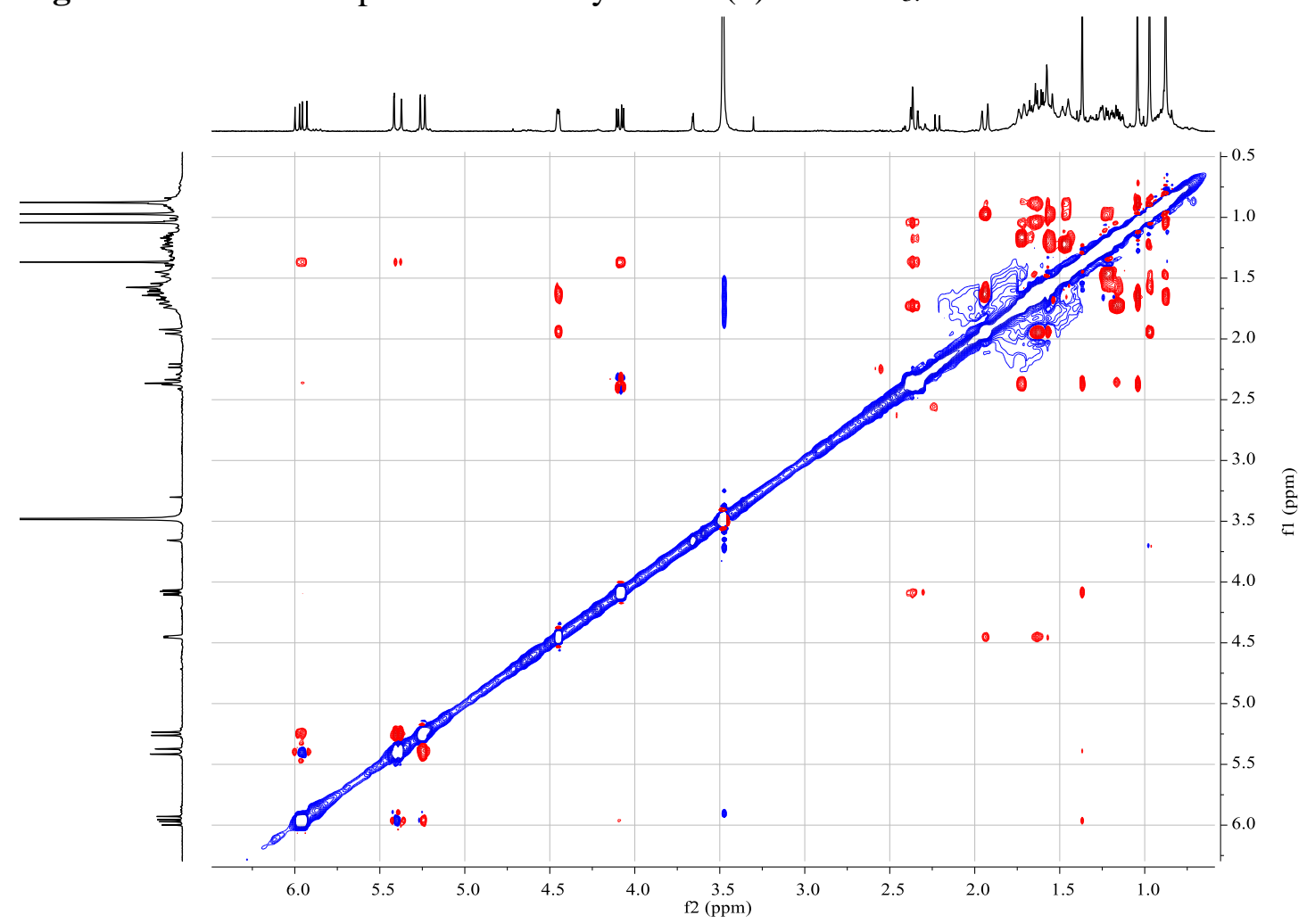


Figure S13. (+)-HRESIMS spectrum of sublyratin A (1).

\section{Qualitative Analysis Report}

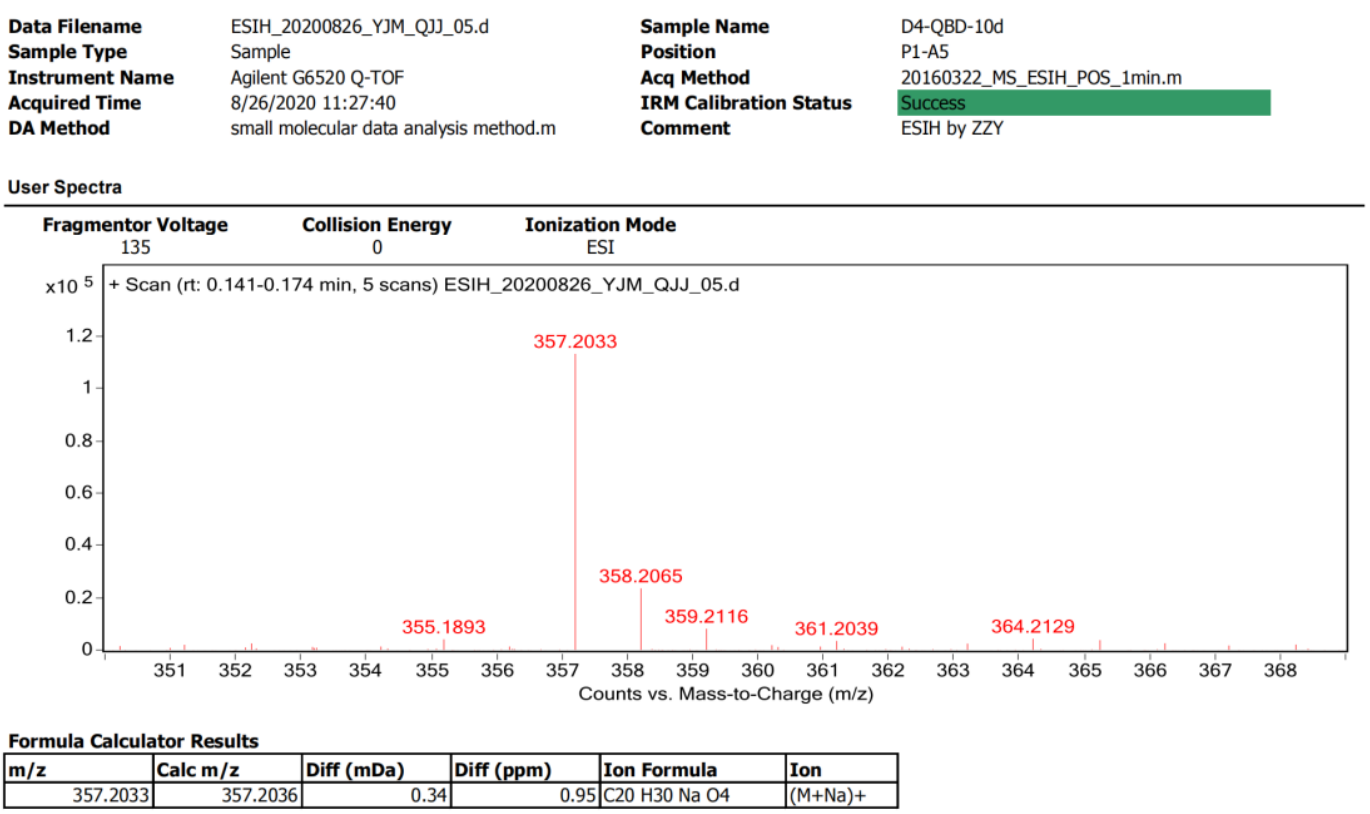

--- End Of Report --- 
Figure S14. ${ }^{1} \mathrm{H}$ NMR spectrum of sublyratin $\mathrm{B}(2)$ in $\mathrm{CDCl}_{3}$.

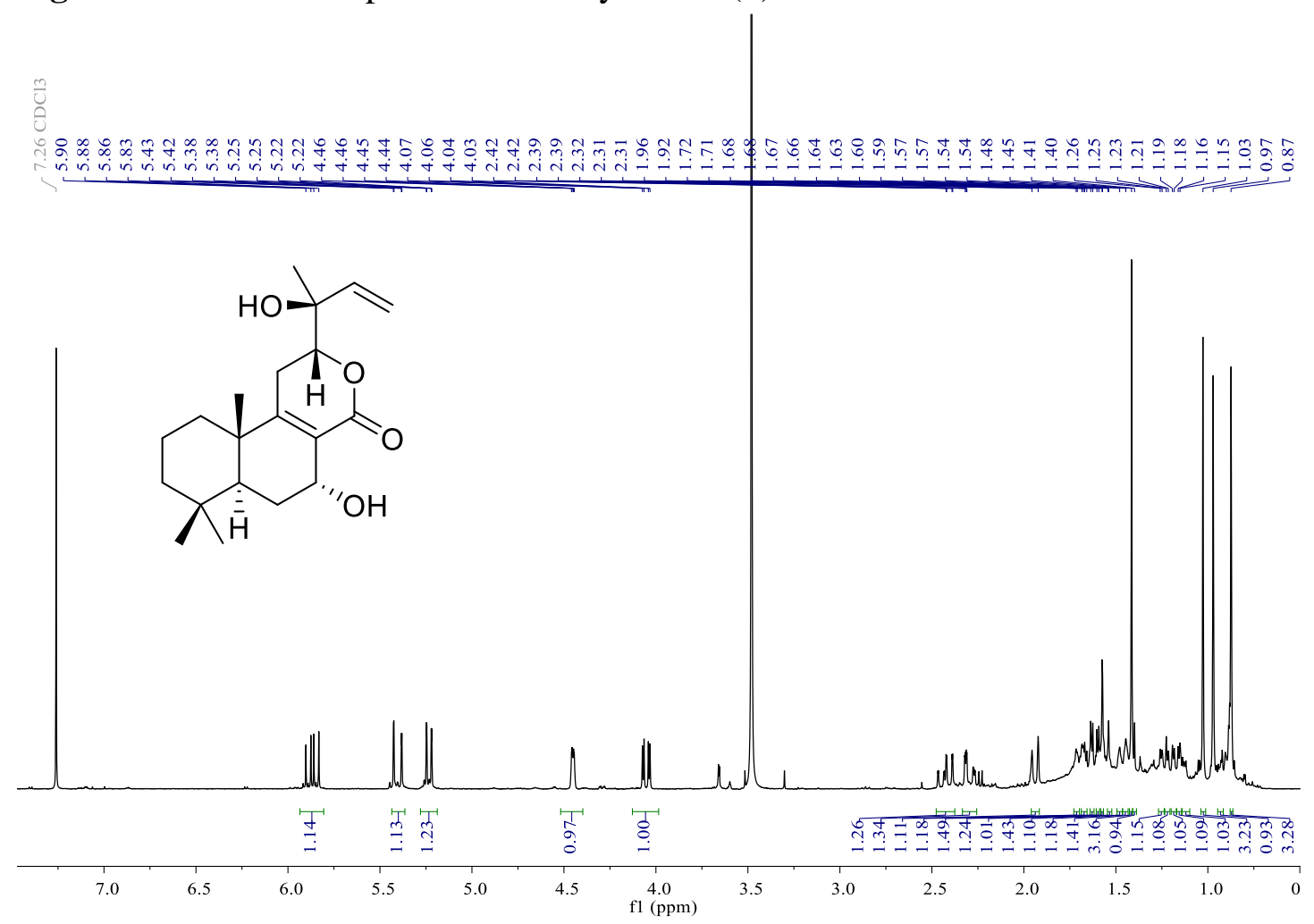

Figure S15. ${ }^{13} \mathrm{C}$ NMR spectrum of sublyratin $\mathrm{B}(2)$ in $\mathrm{CDCl}_{3}$.<smiles>C=C[C@](C)(O)[C@@]1(C)CC2=C(C(=O)O1)[C@@H](O)CC1C(C)(C)CCC[C@@]21C</smiles>

更

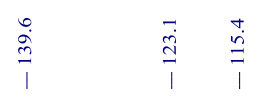
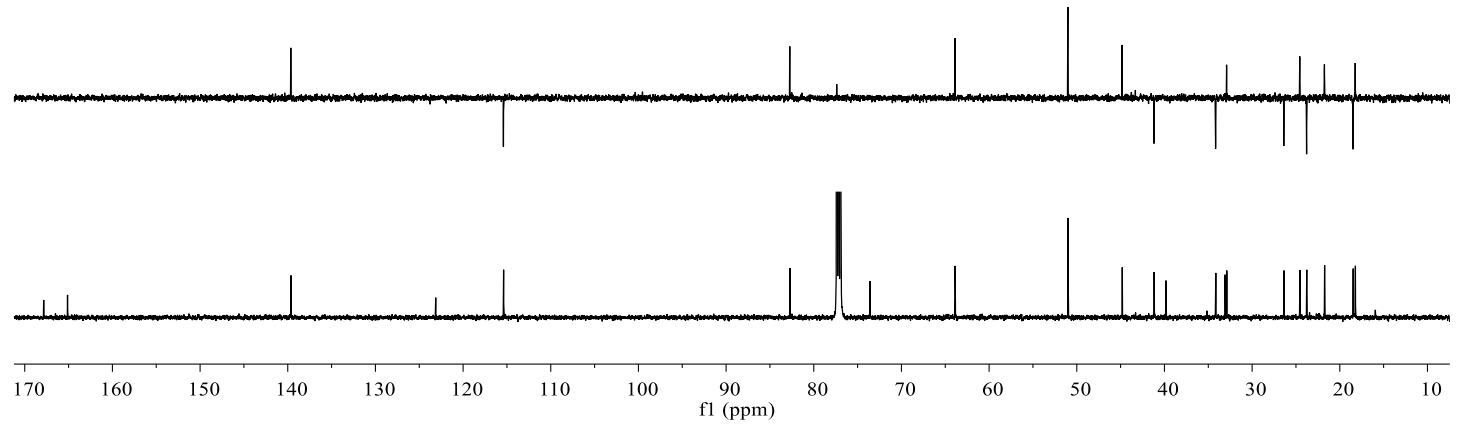
Figure S16. HSQC spectrum of sublyratin B (2) in $\mathrm{CDCl}_{3}$.

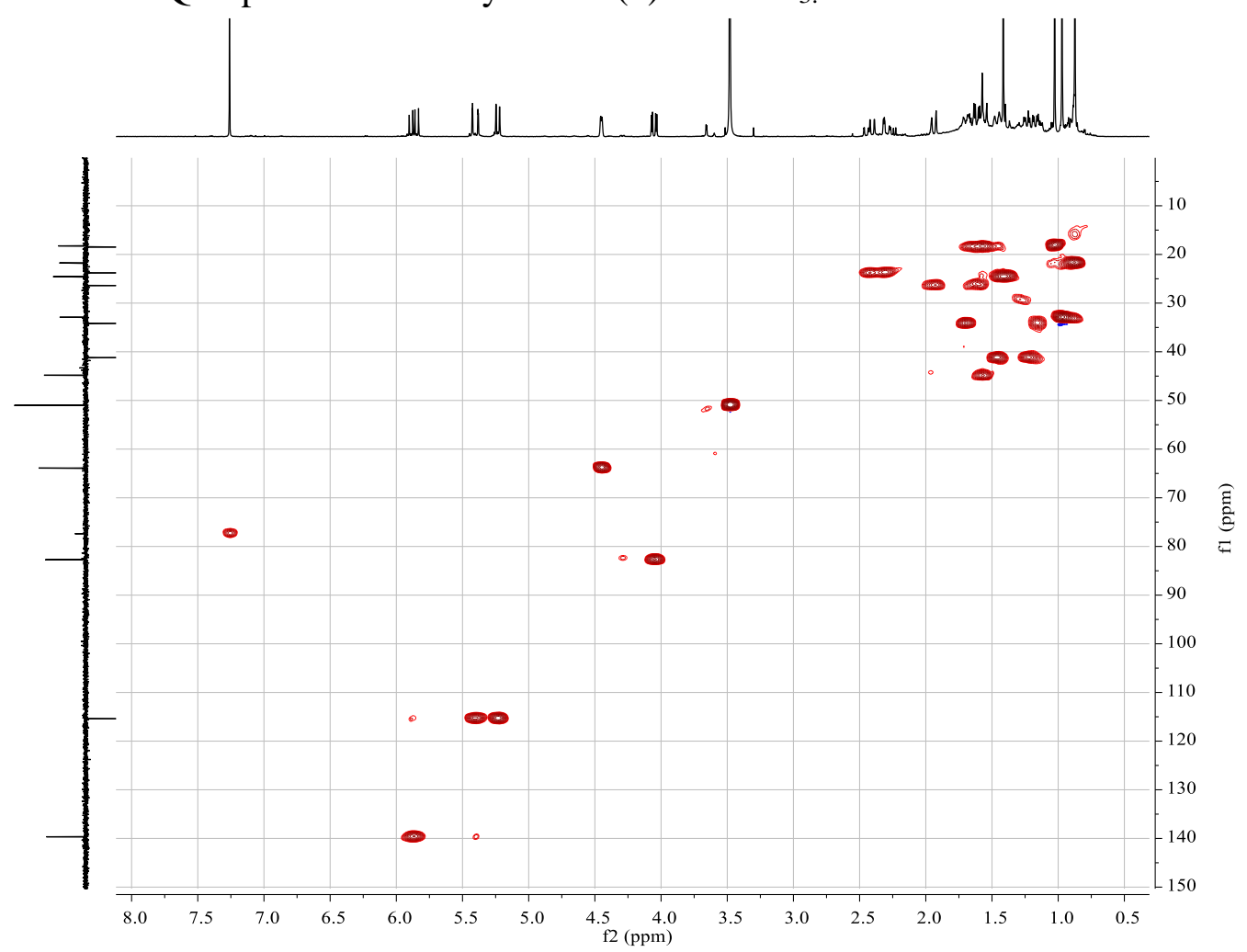

Figure S17. HMBC spectrum of sublyratin $\mathrm{B}(2)$ in $\mathrm{CDCl}_{3}$.

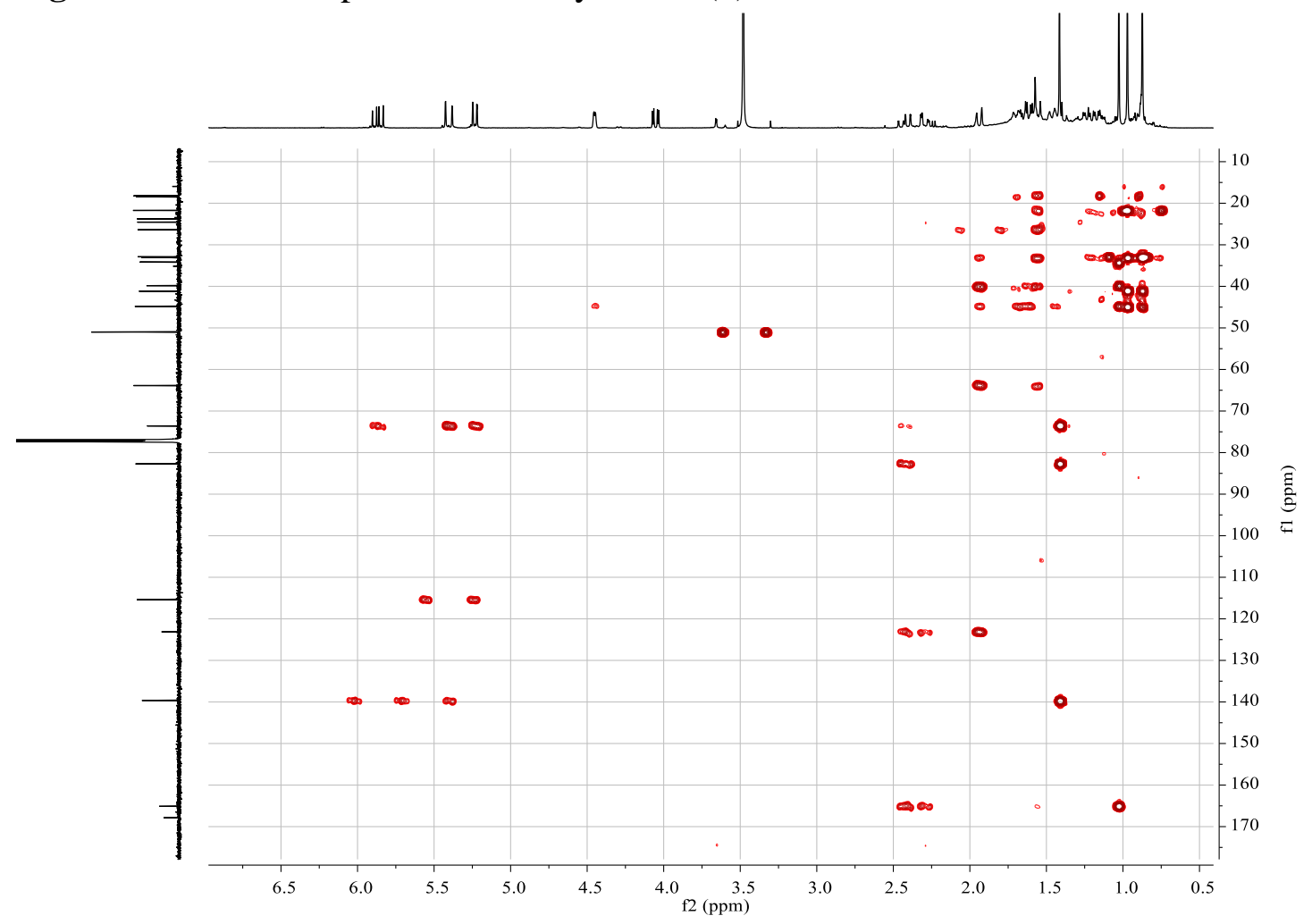


Figure S18. ${ }^{1} \mathrm{H}-{ }^{1} \mathrm{H}$ COSY spectrum of sublyratin $\mathrm{B}(2)$ in $\mathrm{CDCl}_{3}$.

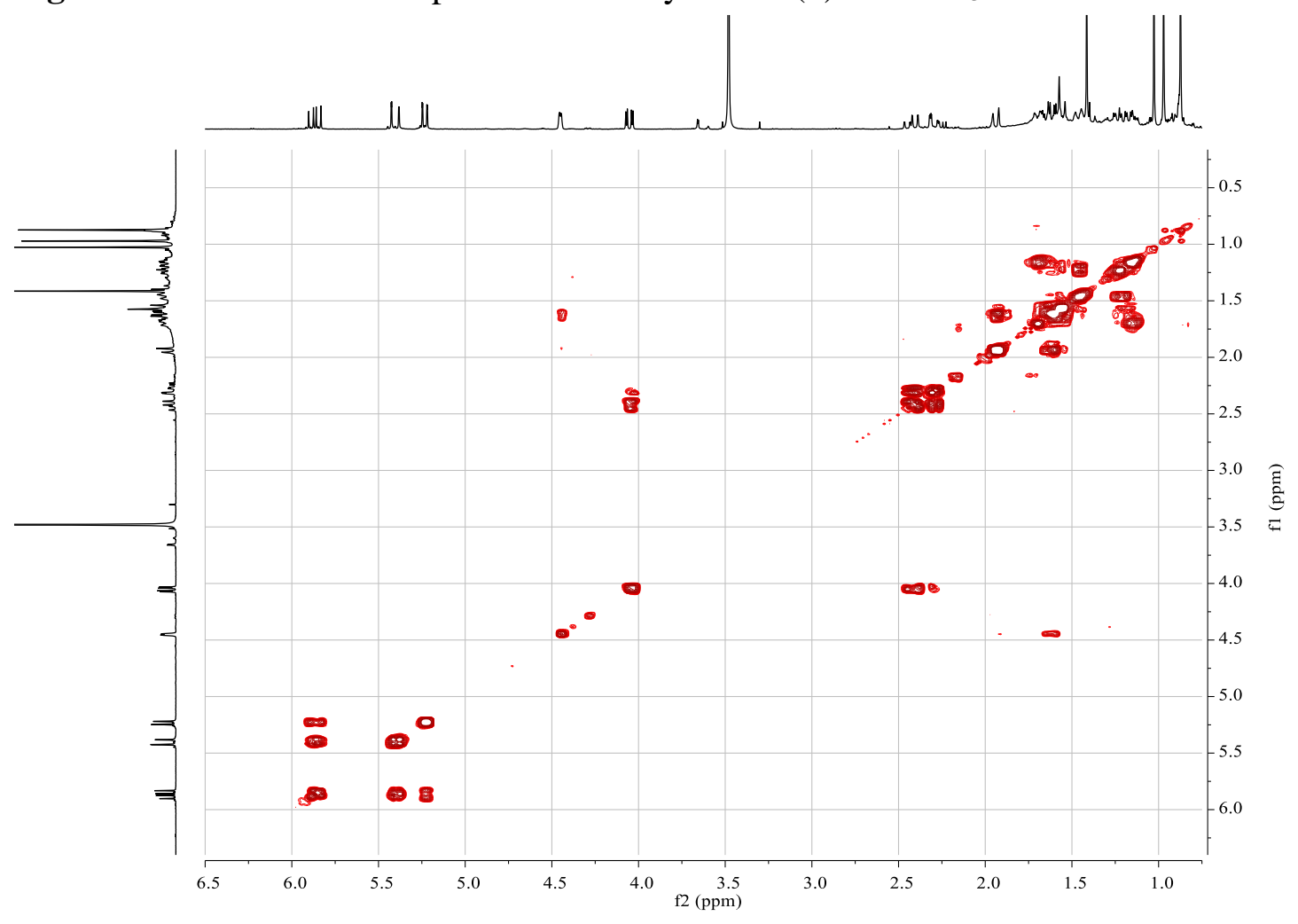

Figure S19. NOESY spectrum of sublyratin B (2) in $\mathrm{CDCl}_{3}$.

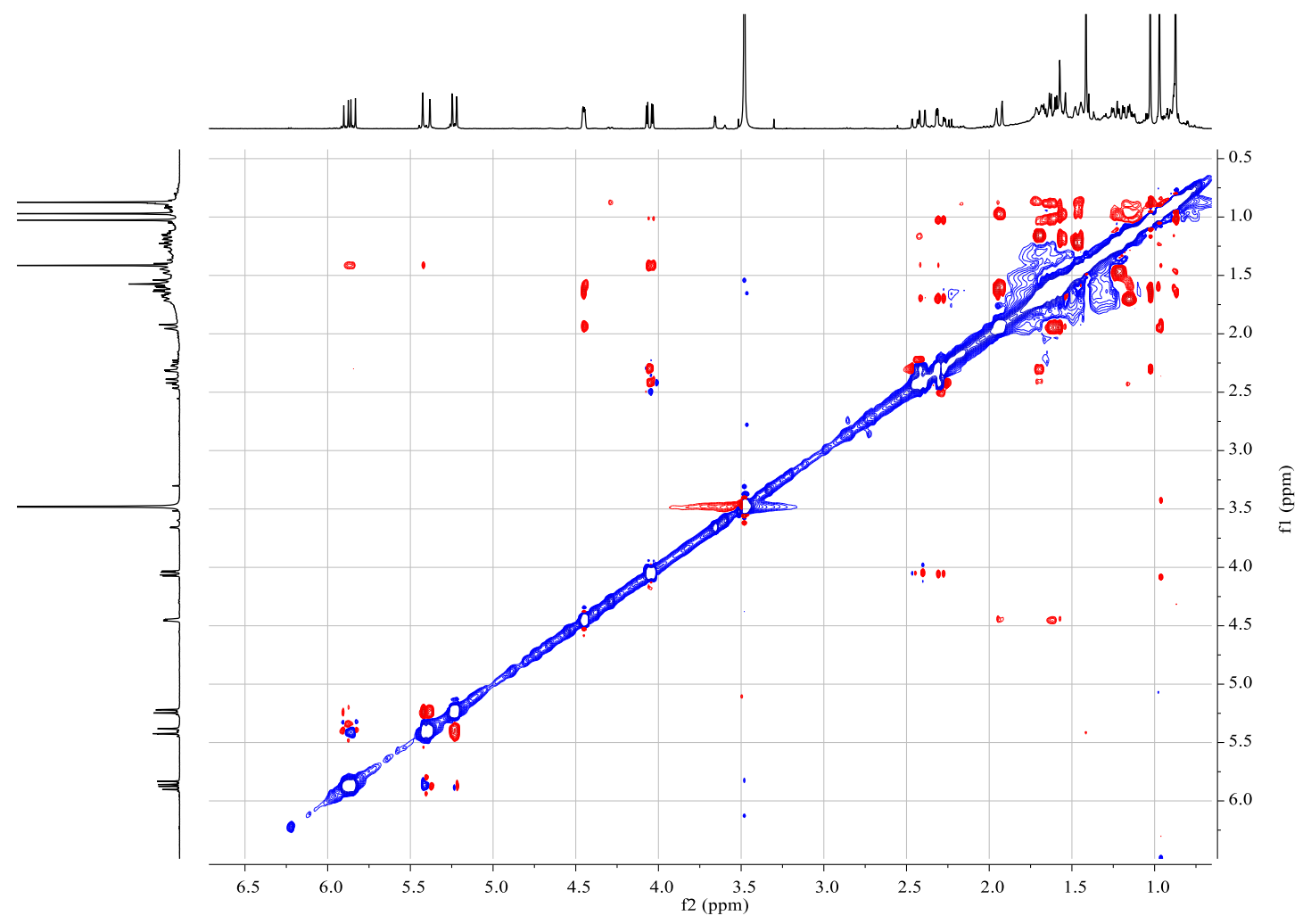


Figure S20. (+)-HRESIMS spectrum of sublyratin B (2).

Qualitative Analysis Report

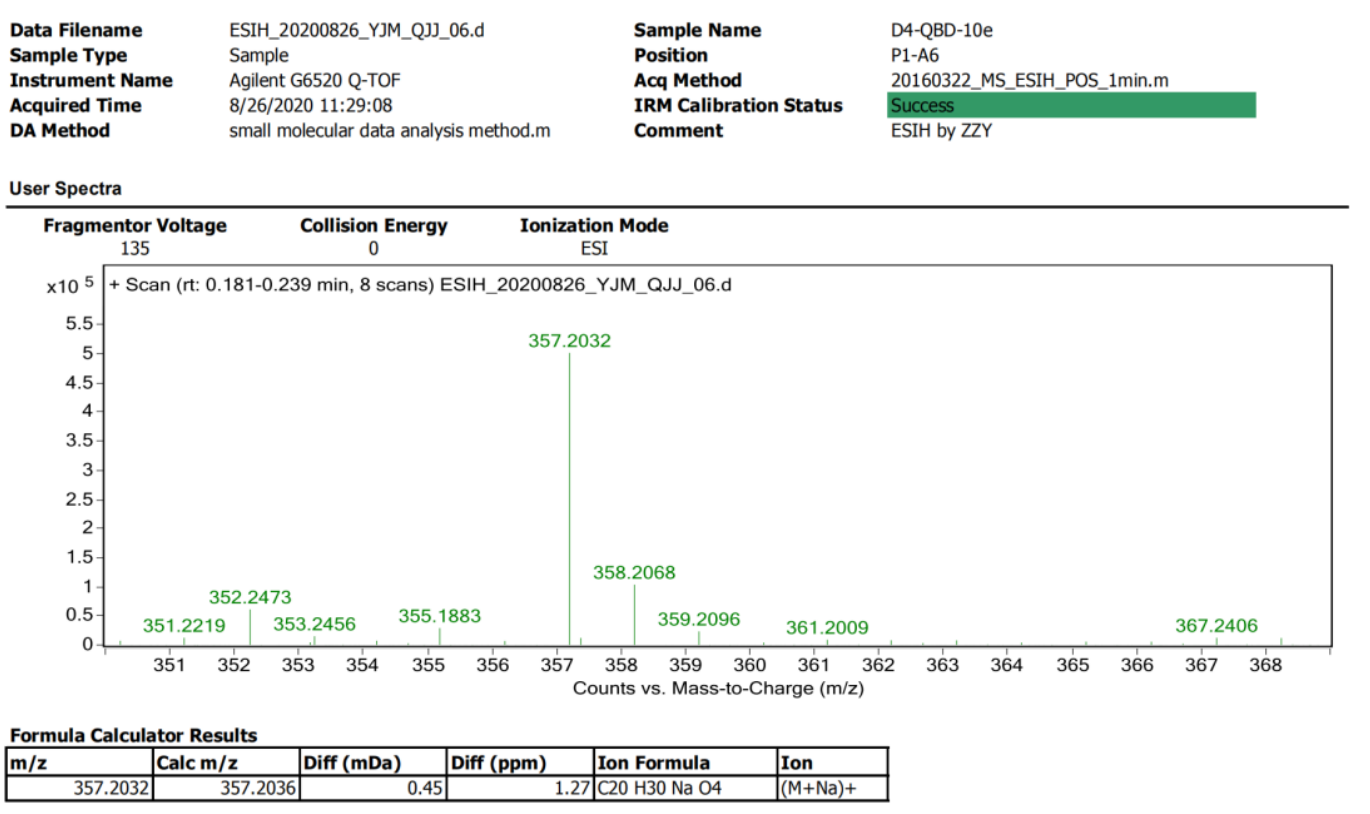

--- End Of Report --- 
Figure S21. ${ }^{1} \mathrm{H}$ NMR spectrum of sublyratin $\mathrm{C}(\mathbf{3})$ in $\mathrm{CDCl}_{3}$.

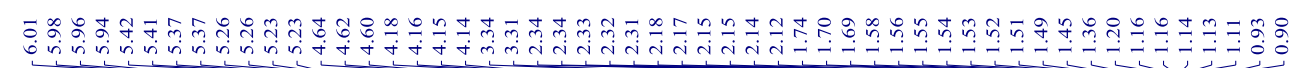<smiles></smiles>

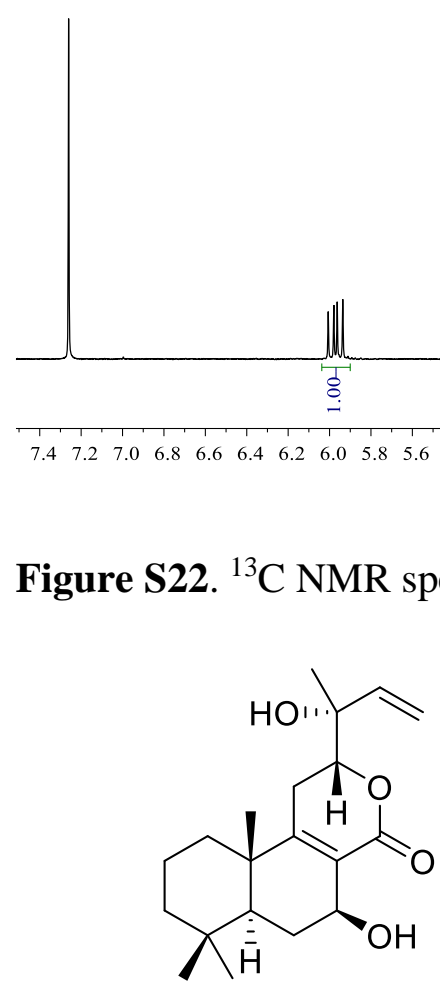

\section{yratin $\mathrm{C}(\mathbf{3})$ in $\mathrm{CDCl}_{3}$.}


Figure S23. HSQC spectrum of sublyratin C (3) in $\mathrm{CDCl}_{3}$.

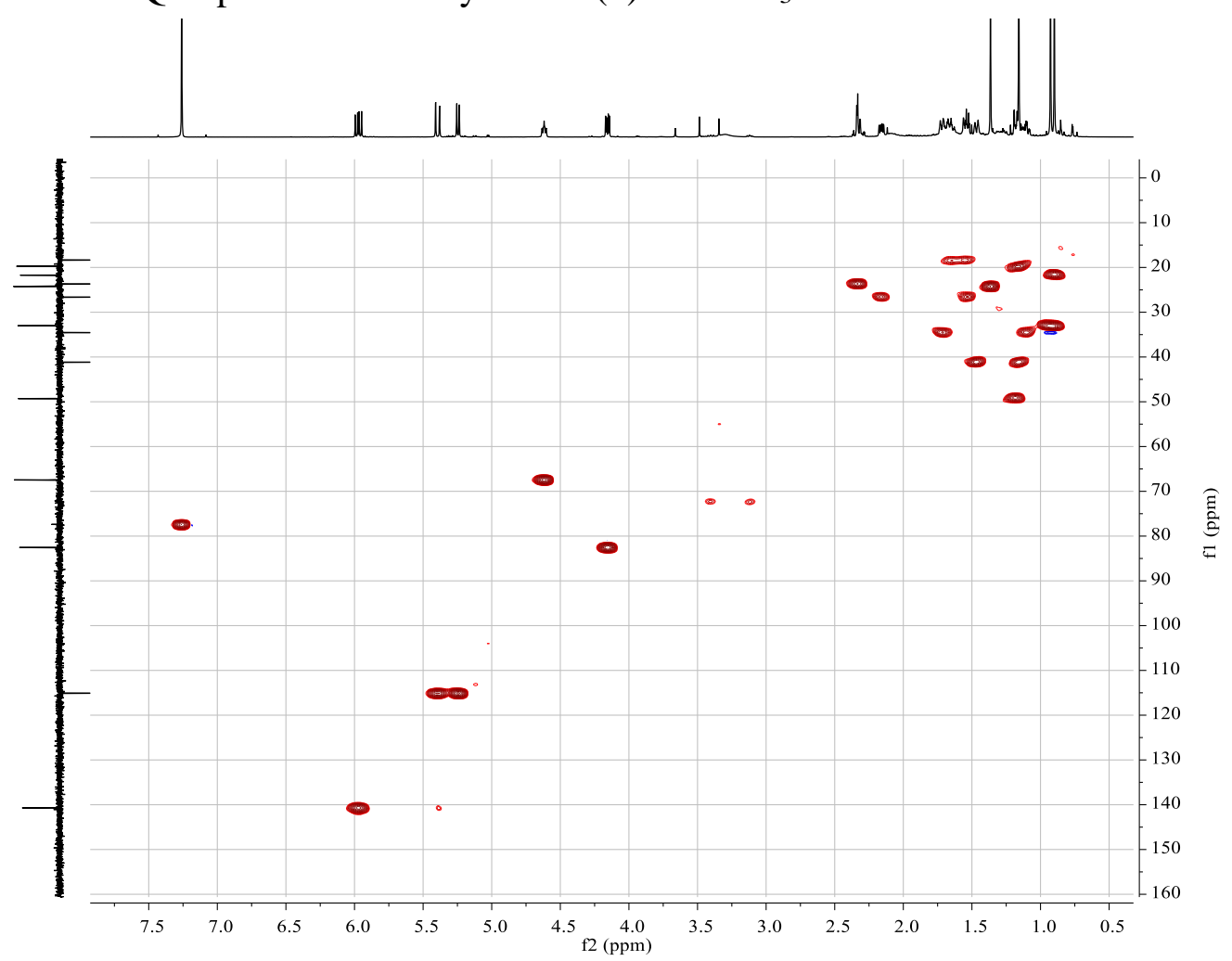

Figure S24. HMBC spectrum of sublyratin C (3) in $\mathrm{CDCl}_{3}$.

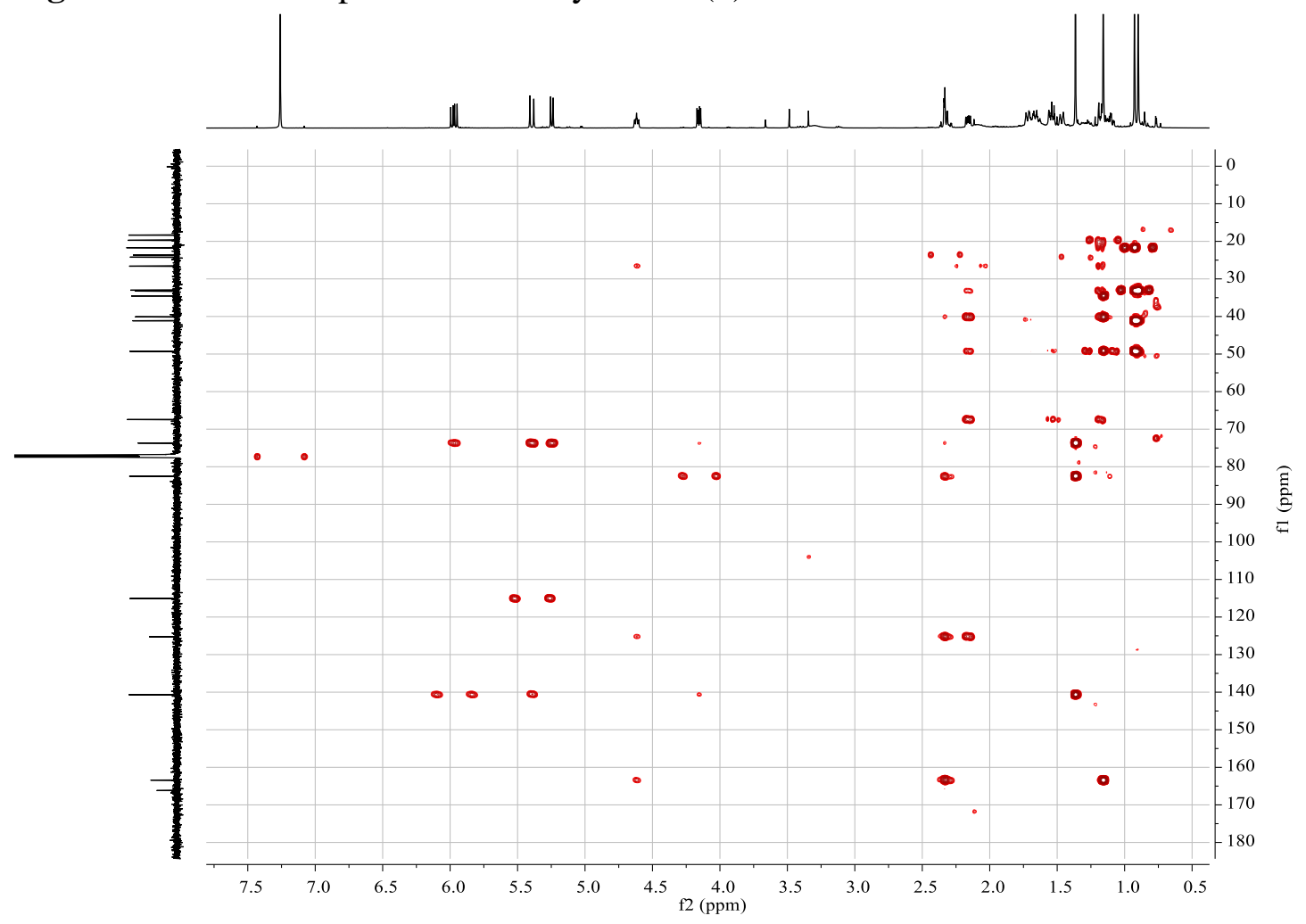


Figure S25. ${ }^{1} \mathrm{H}-{ }^{1} \mathrm{H}$ COSY spectrum of sublyratin $\mathrm{C}(\mathbf{3})$ in $\mathrm{CDCl}_{3}$.

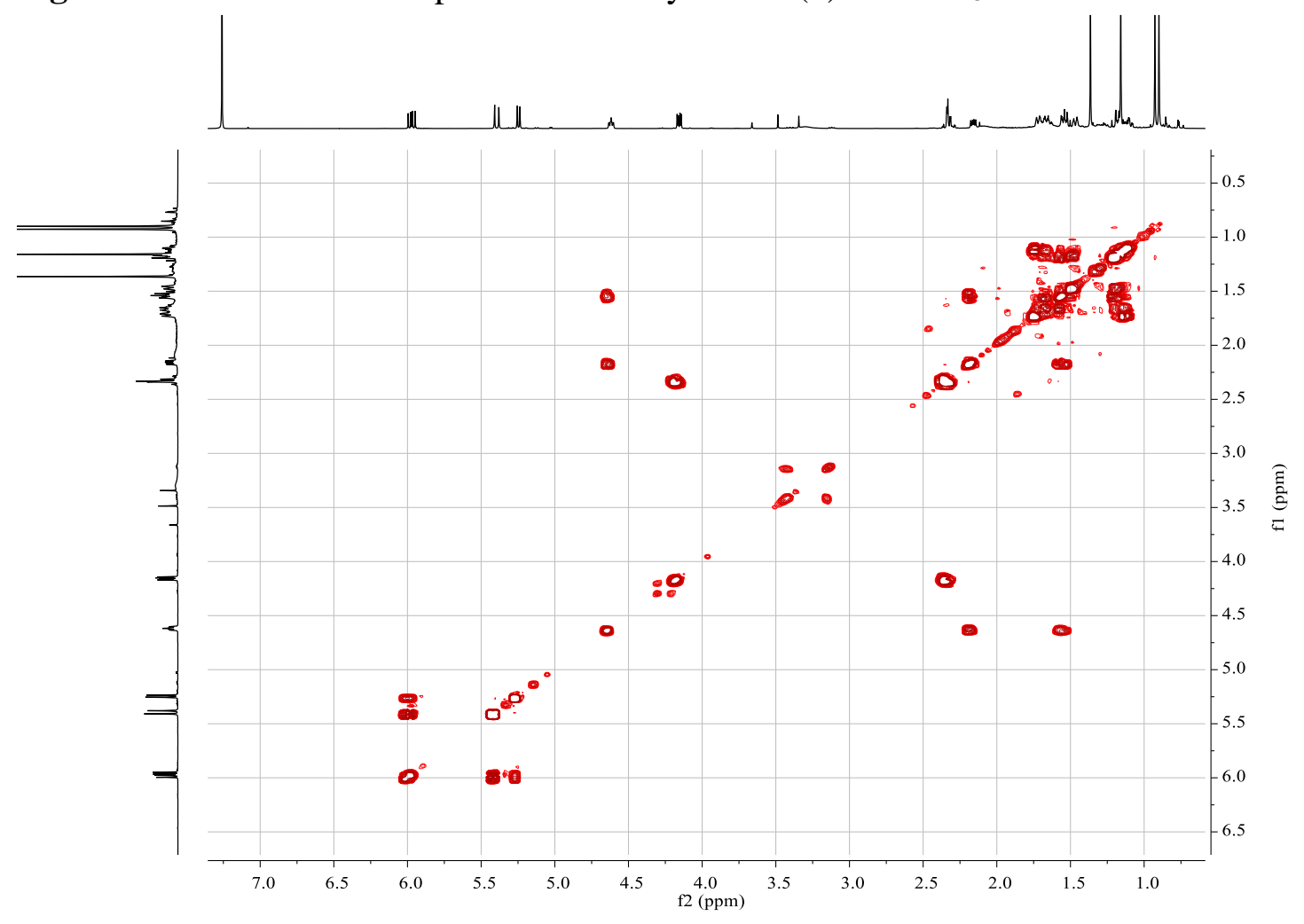

Figure S26. NOESY spectrum of sublyratin C (3) in $\mathrm{CDCl}_{3}$.

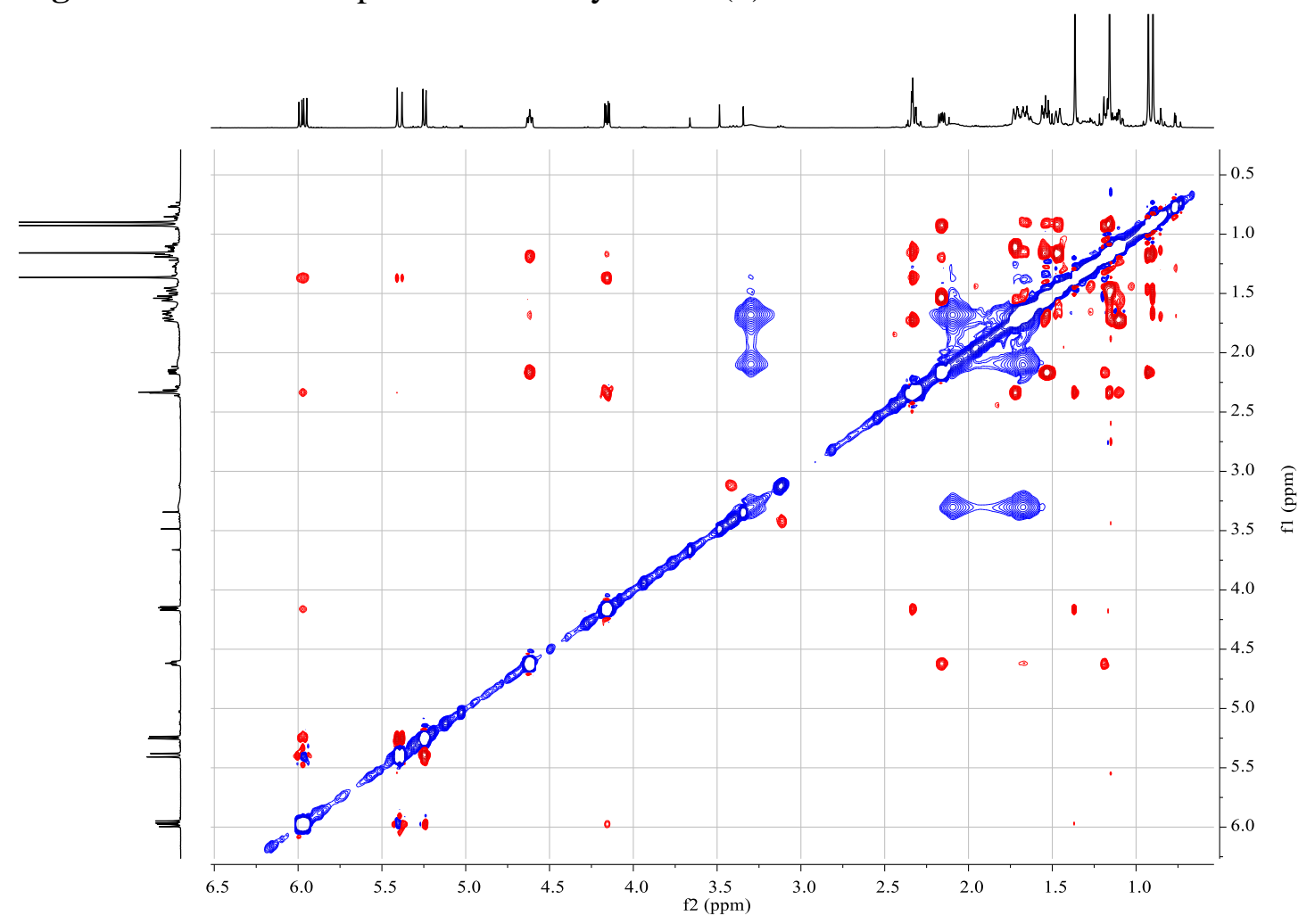


Figure S27. (+)-HRESIMS spectrum of sublyratin C (3).

Qualitative Analysis Report

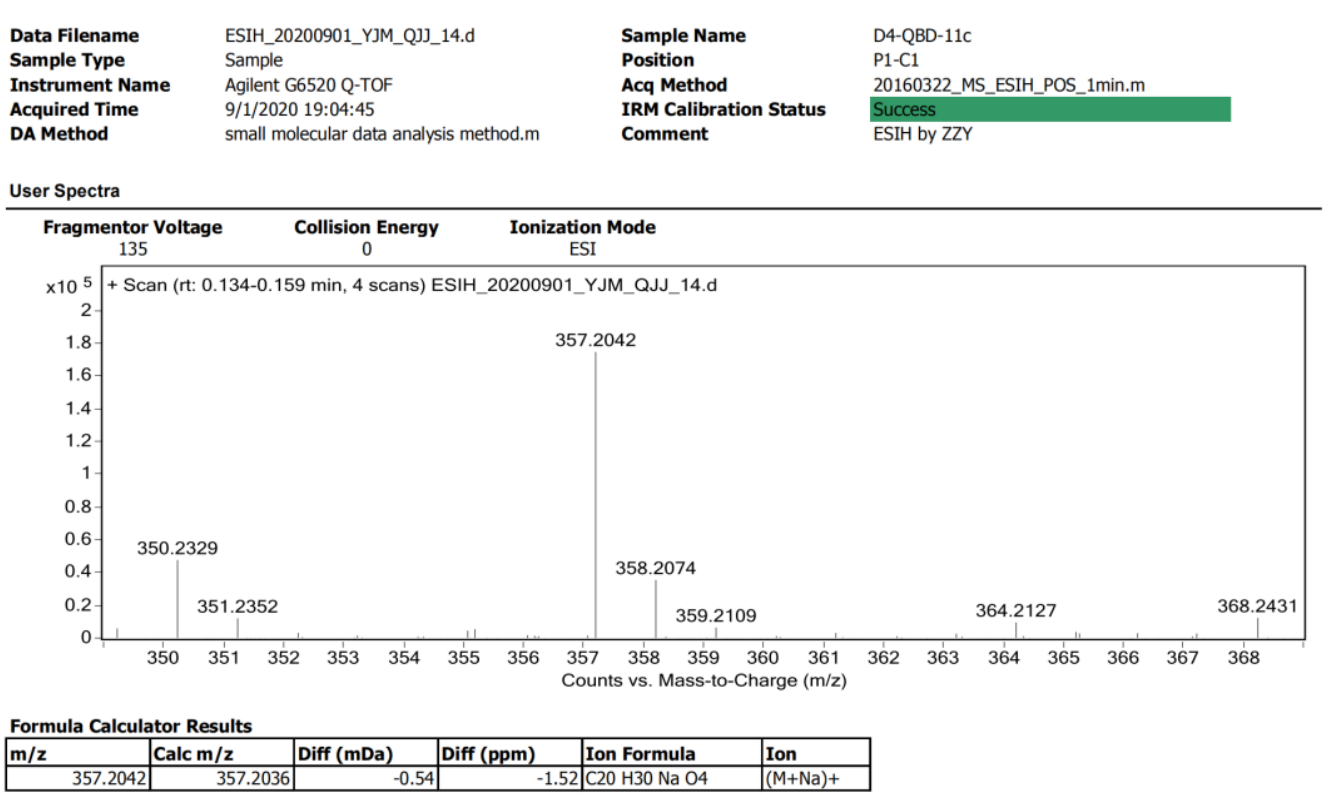

--- End Of Report -.- 
Figure S28. ${ }^{1} \mathrm{H}$ NMR spectrum of sublyratin $\mathrm{D}(\mathbf{4})$ in $\mathrm{CDCl}_{3}$.

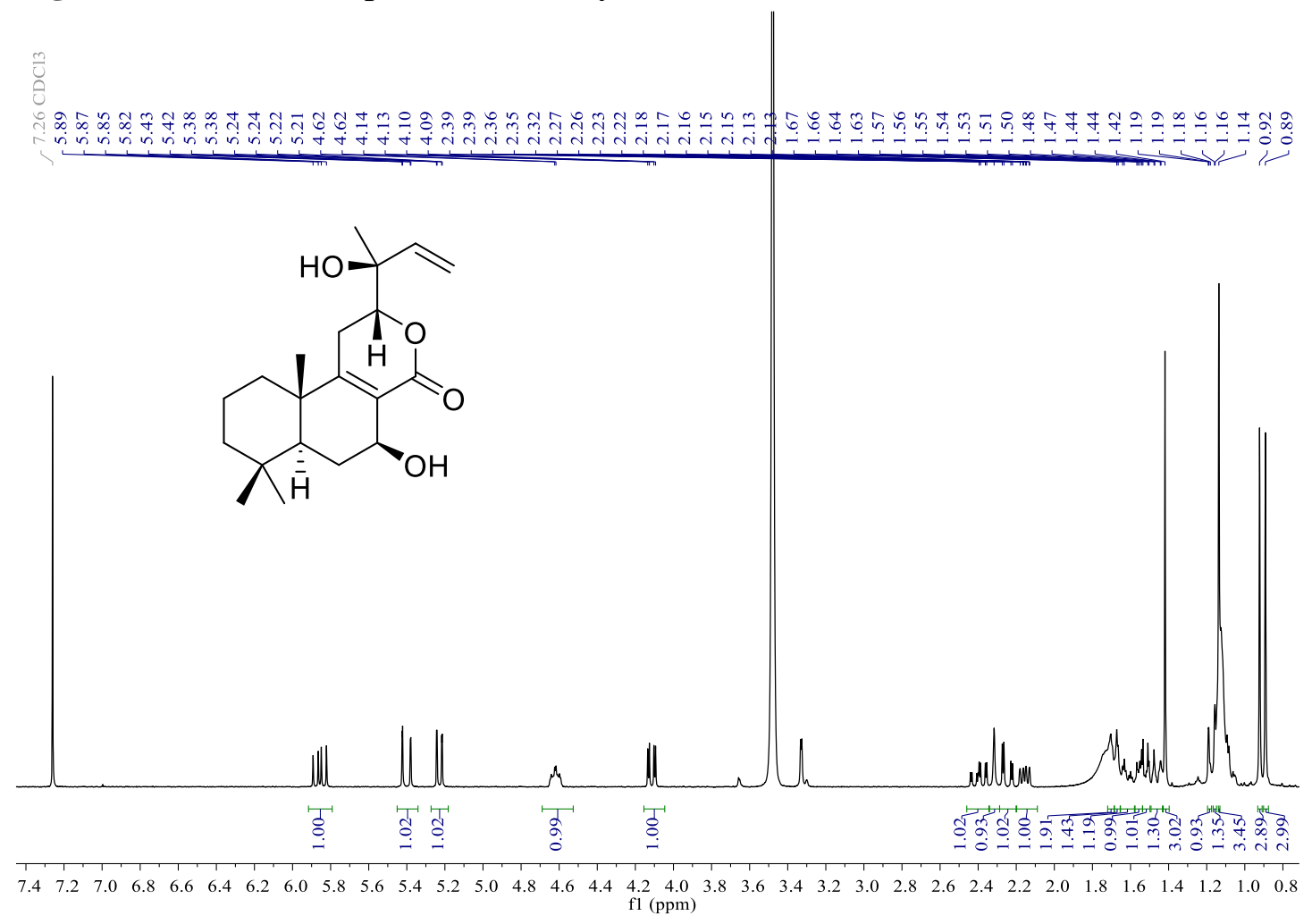

Figure S29. ${ }^{13} \mathrm{C}$ NMR spectrum of sublyratin D (4) in $\mathrm{CDCl}_{3}$.<smiles>C=CC(C)(O)[C@@]12CC3=C(C(=O)O1)[C@@H](O)C[C@@H]1C(=C2O)[C@@]3(C)CCC[C@@H]1C</smiles>

$\frac{1}{1}$

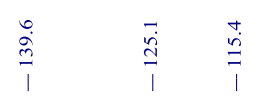
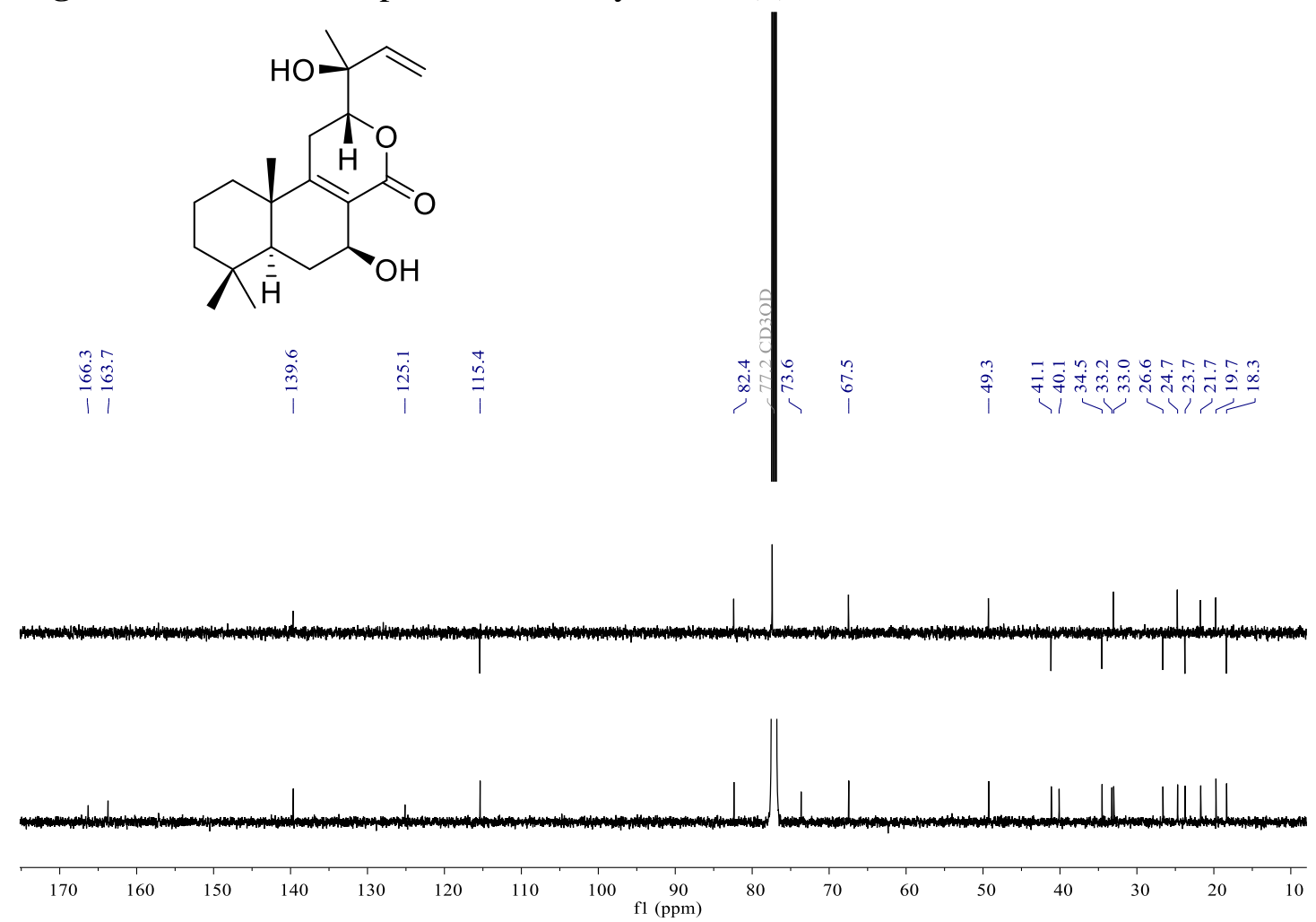
Figure S30. HSQC spectrum of sublyratin D (4) in $\mathrm{CDCl}_{3}$.

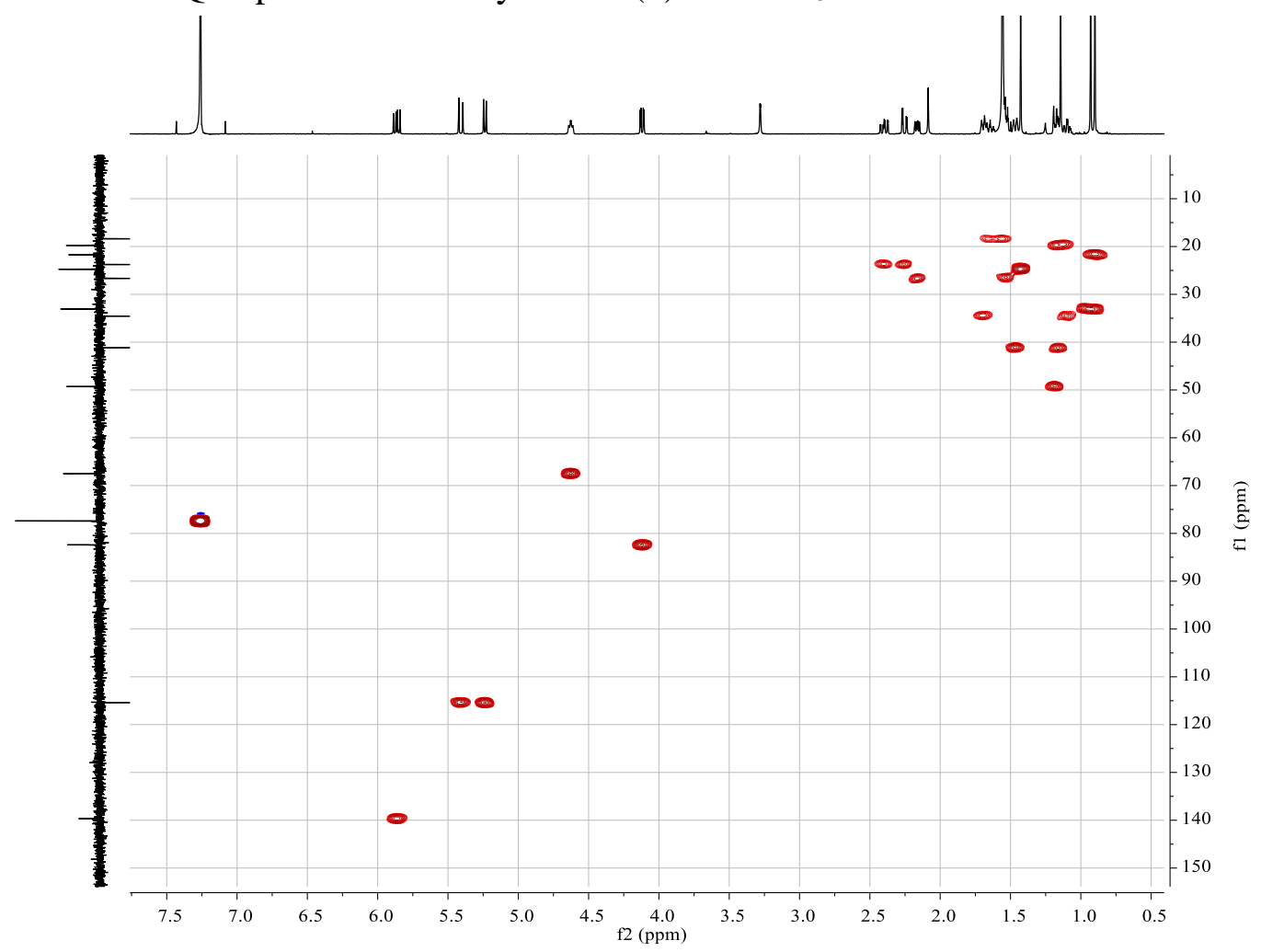

Figure S31. HMBC spectrum of sublyratin D (4) in $\mathrm{CDCl}_{3}$.

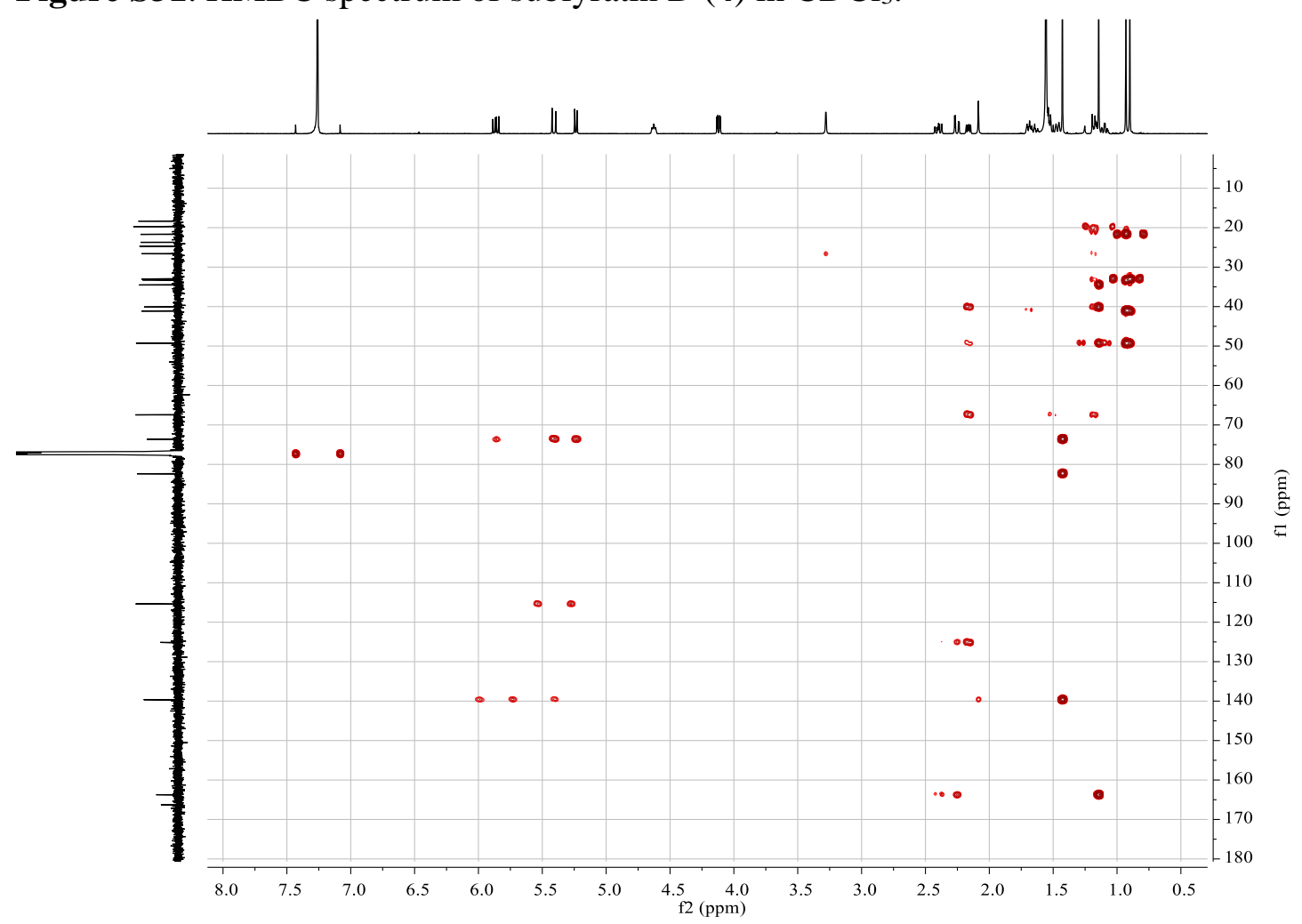

25 
Figure S32. ${ }^{1} \mathrm{H}-{ }^{1} \mathrm{H}$ COSY spectrum of sublyratin $\mathrm{D}(4)$ in $\mathrm{CDCl}_{3}$.

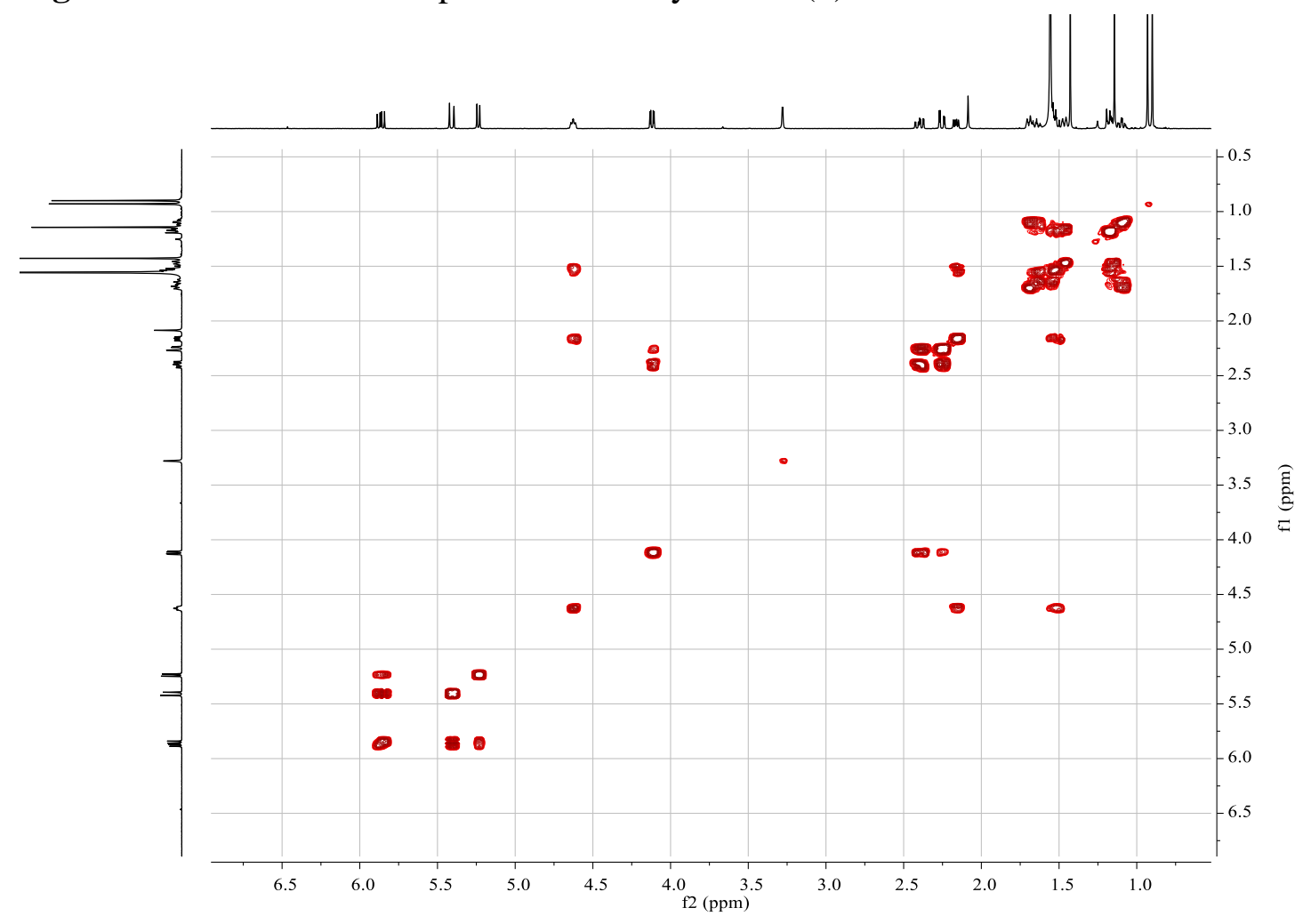

Figure S33. NOESY spectrum of sublyratin D (4) in $\mathrm{CDCl}_{3}$.

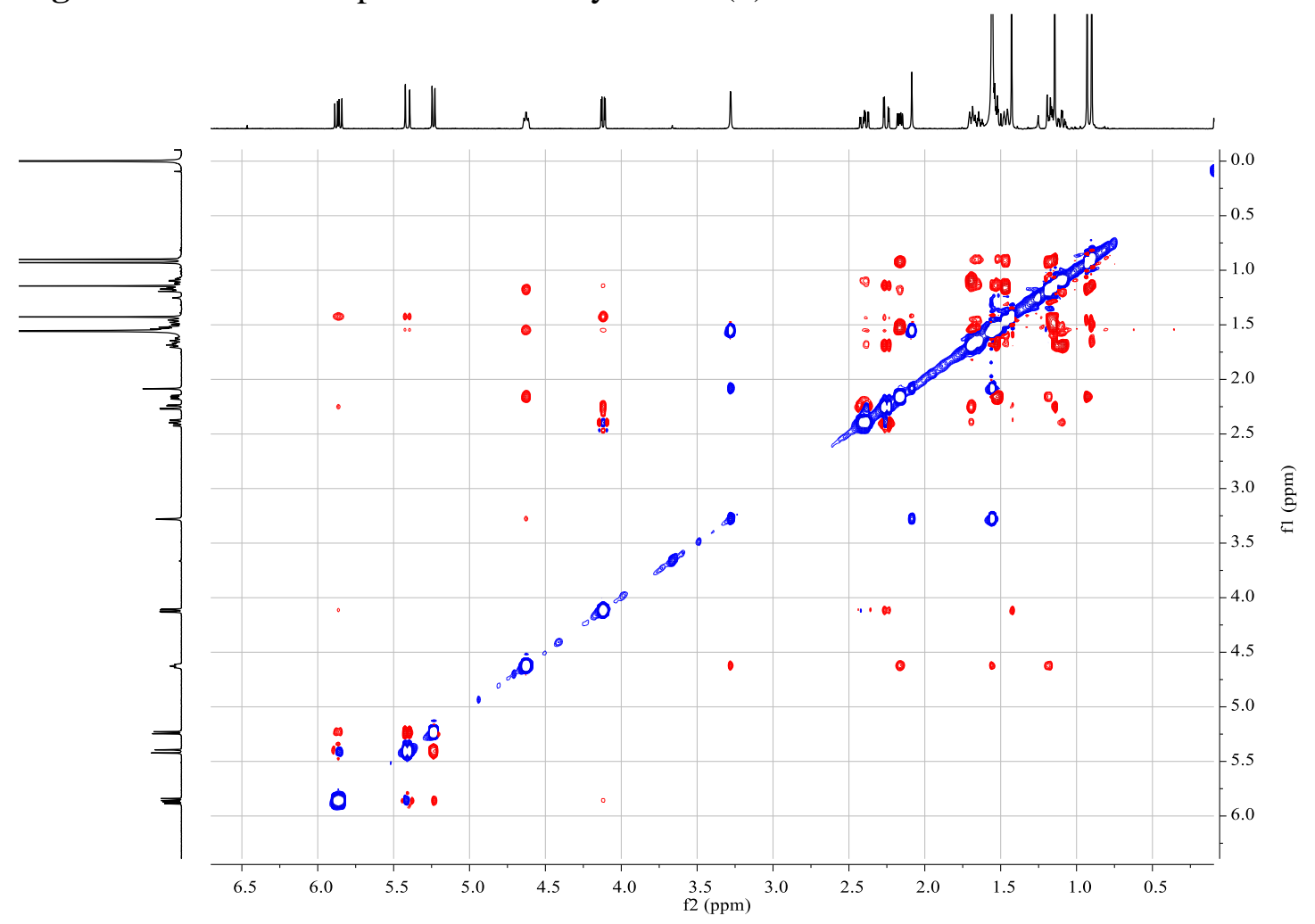


Figure S34. (+)-HRESIMS spectrum of sublyratin D (4).

Qualitative Analysis Report

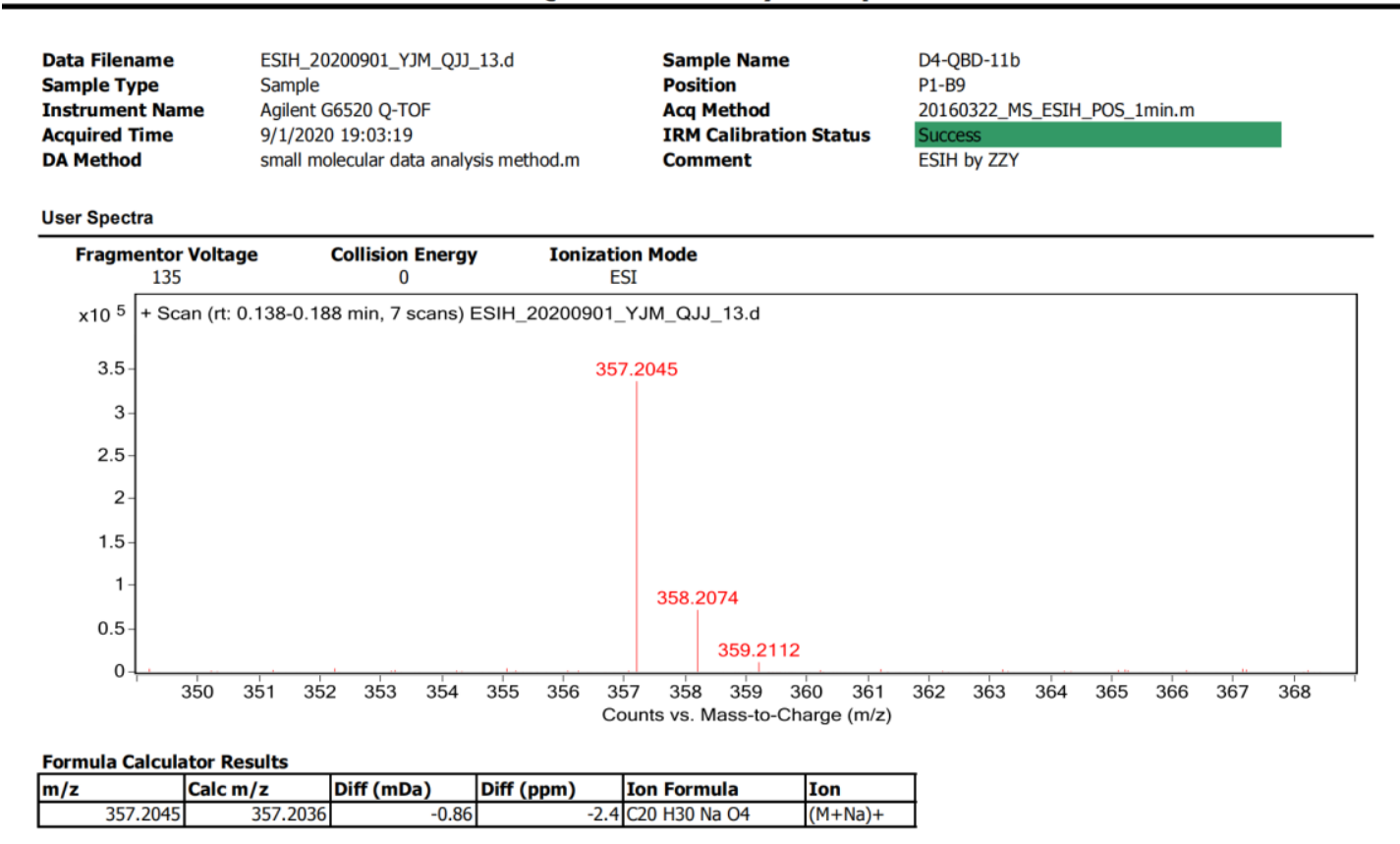

--- End Of Report --- 
Figure S35. ${ }^{1} \mathrm{H}$ NMR spectrum of sublyratin $\mathrm{E}(\mathbf{5})$ in $\mathrm{CDCl}_{3}$.

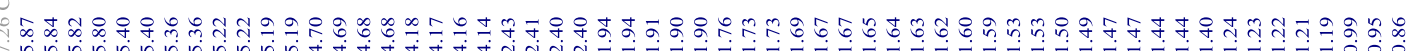<smiles>C=C[C@](C)(O)[C@@H]1CC2=C(C(=O)O1)[C@@H](O)C[C@H]1C(C)(C)CCC[C@@]21C</smiles>

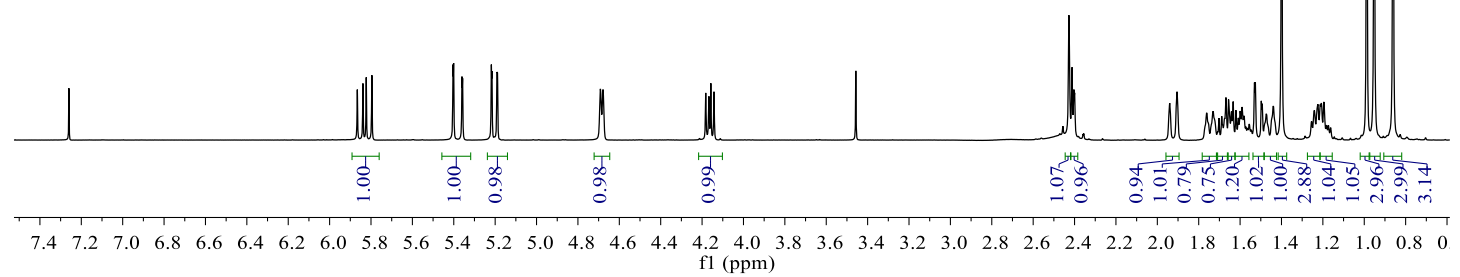

Figure S36. ${ }^{13} \mathrm{C}$ NMR spectrum of sublyratin $\mathrm{E}(\mathbf{5})$ in $\mathrm{CDCl}_{3}$.<smiles>C=CC(C)(O)[C@@H]1CC2=C(C(=O)O1)[C@@H](O)C[C@H]1[C@@H](C)CCC[C@@]21C</smiles>

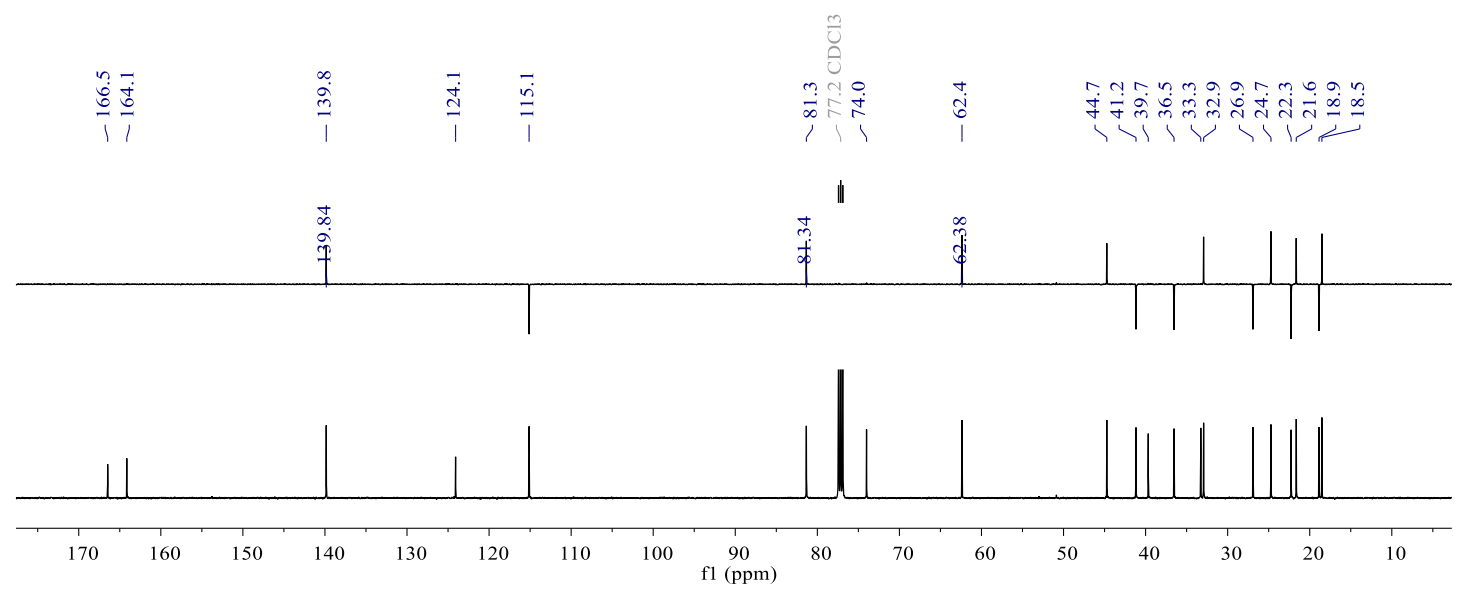


Figure S37. HSQC spectrum of sublyratin E (5) in $\mathrm{CDCl}_{3}$.

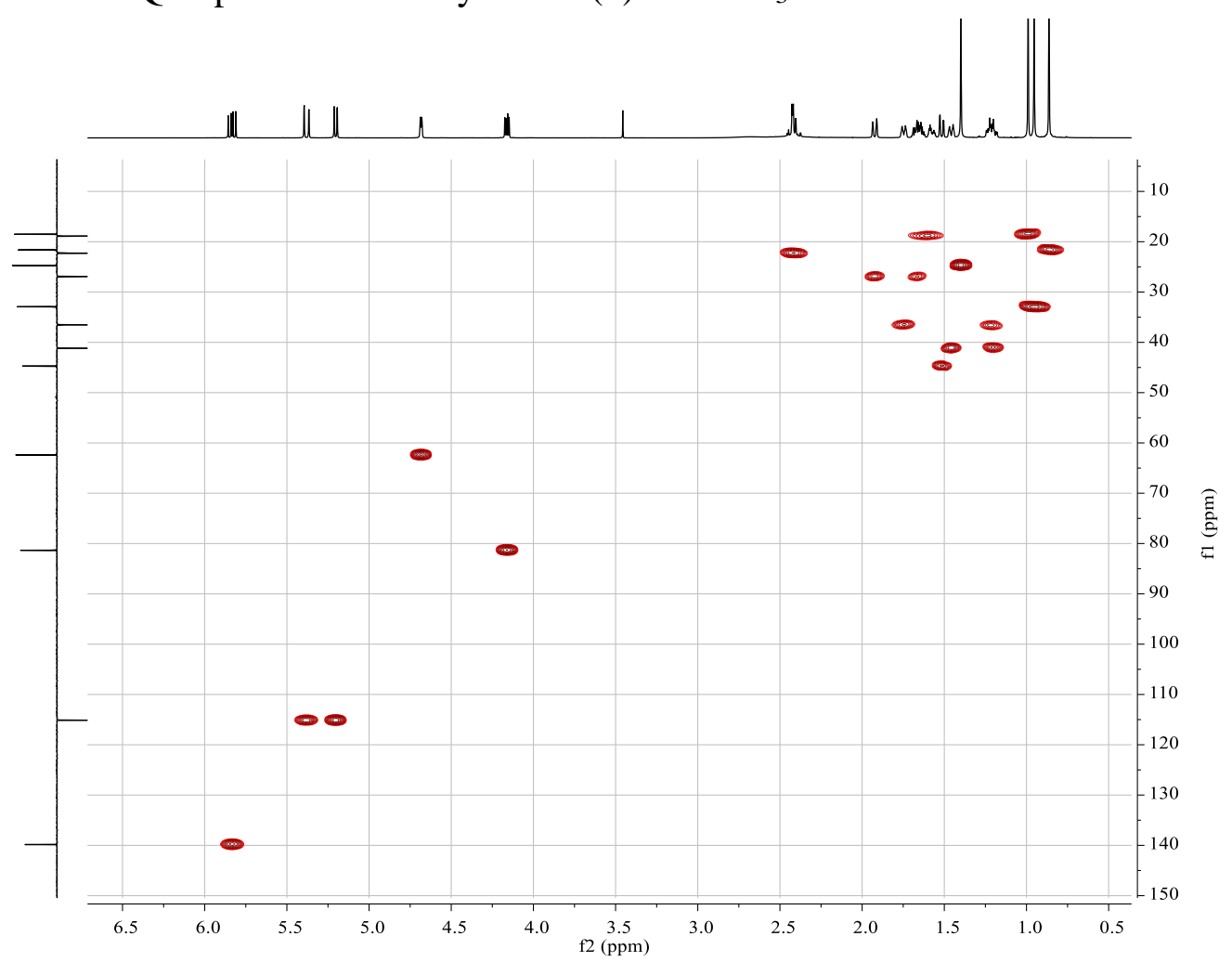

Figure S38. HMBC spectrum of sublyratin E (5) in $\mathrm{CDCl}_{3}$.

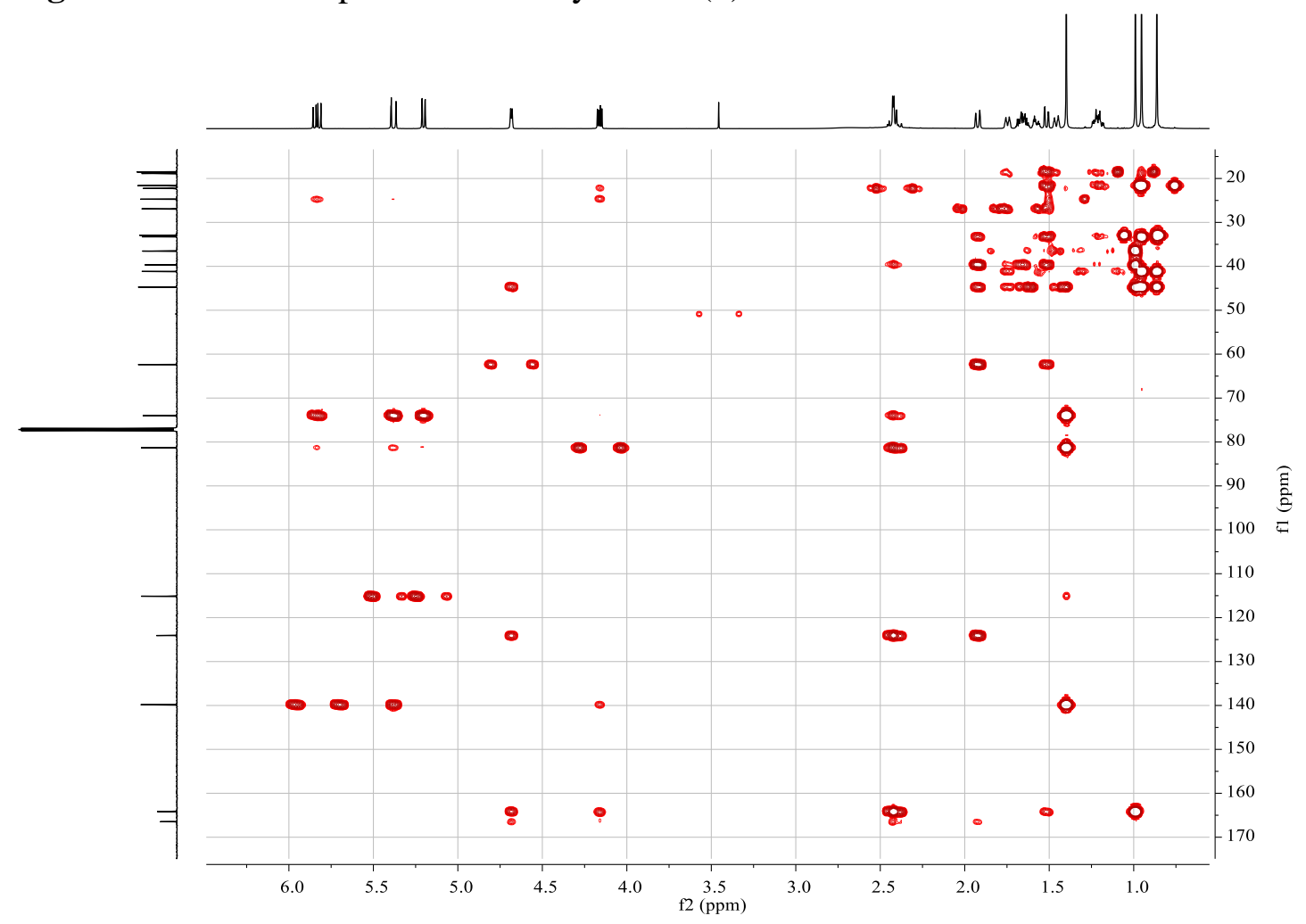


Figure S39. ${ }^{1} \mathrm{H}-{ }^{1} \mathrm{H}$ COSY spectrum of sublyratin $\mathrm{E}(5)$ in $\mathrm{CDCl}_{3}$.

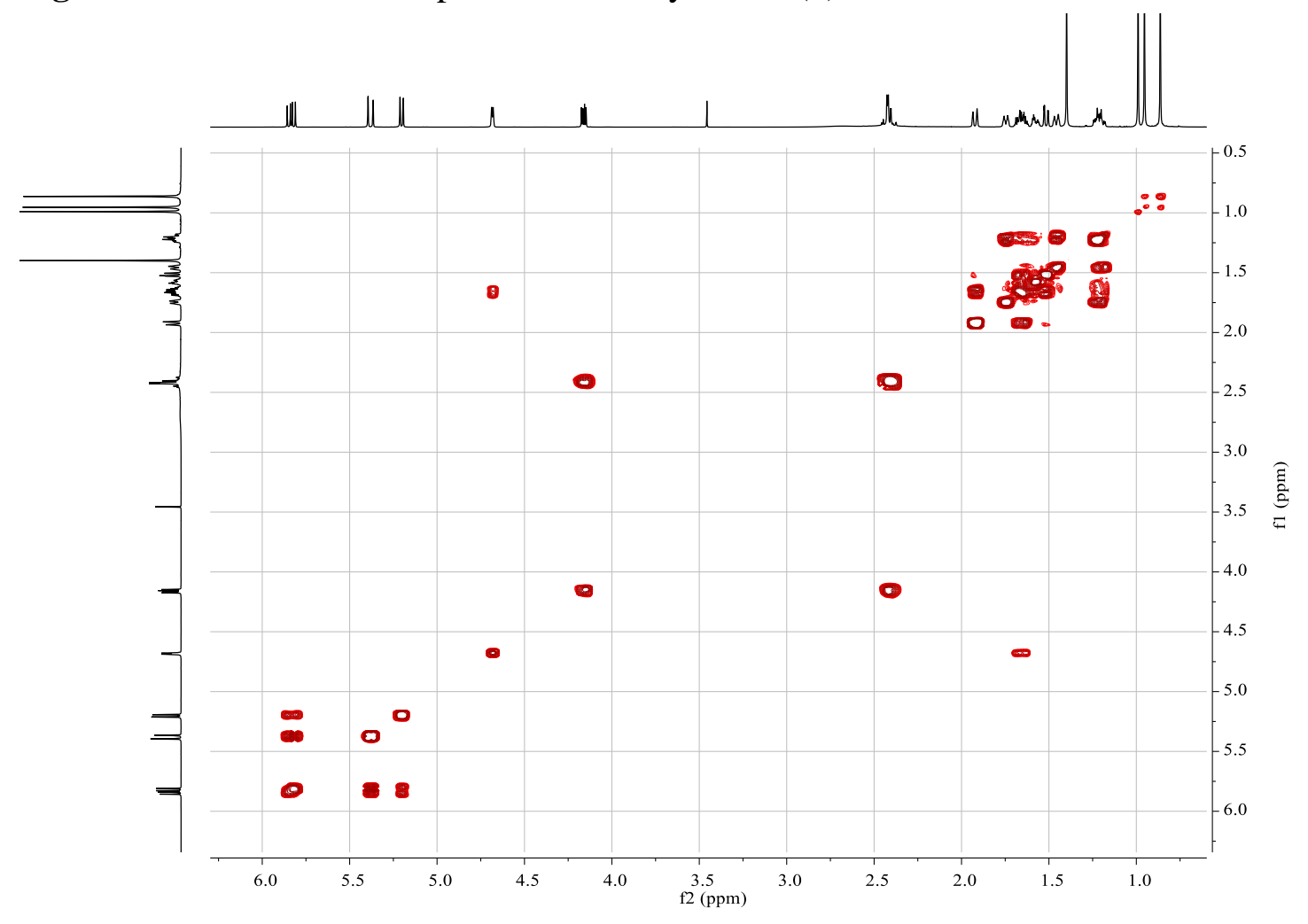

Figure S40. NOESY spectrum of sublyratin E (5) in $\mathrm{CDCl}_{3}$.

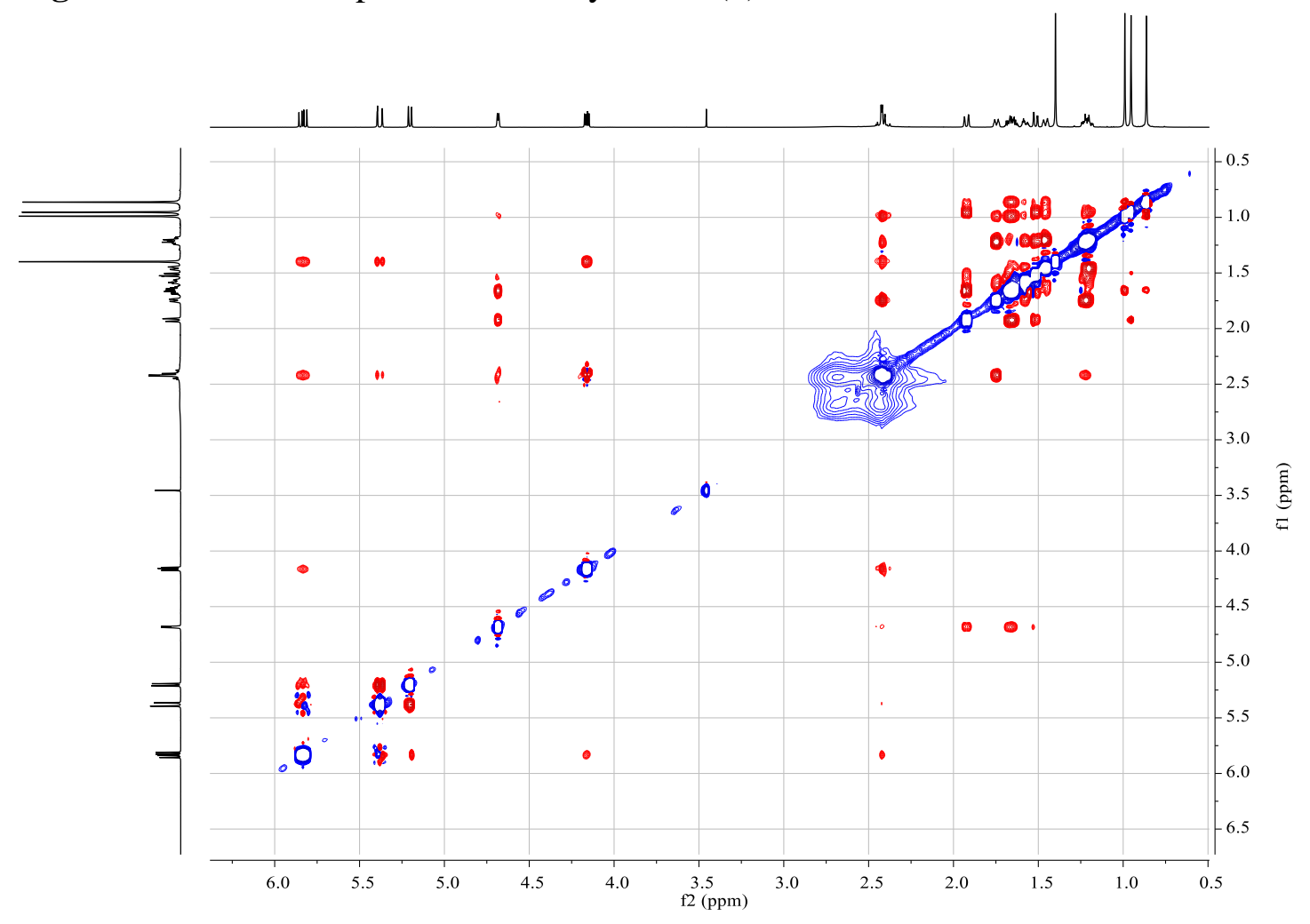


Figure S41. (+)-HRESIMS spectrum of sublyratin E (5).

Qualitative Analysis Report

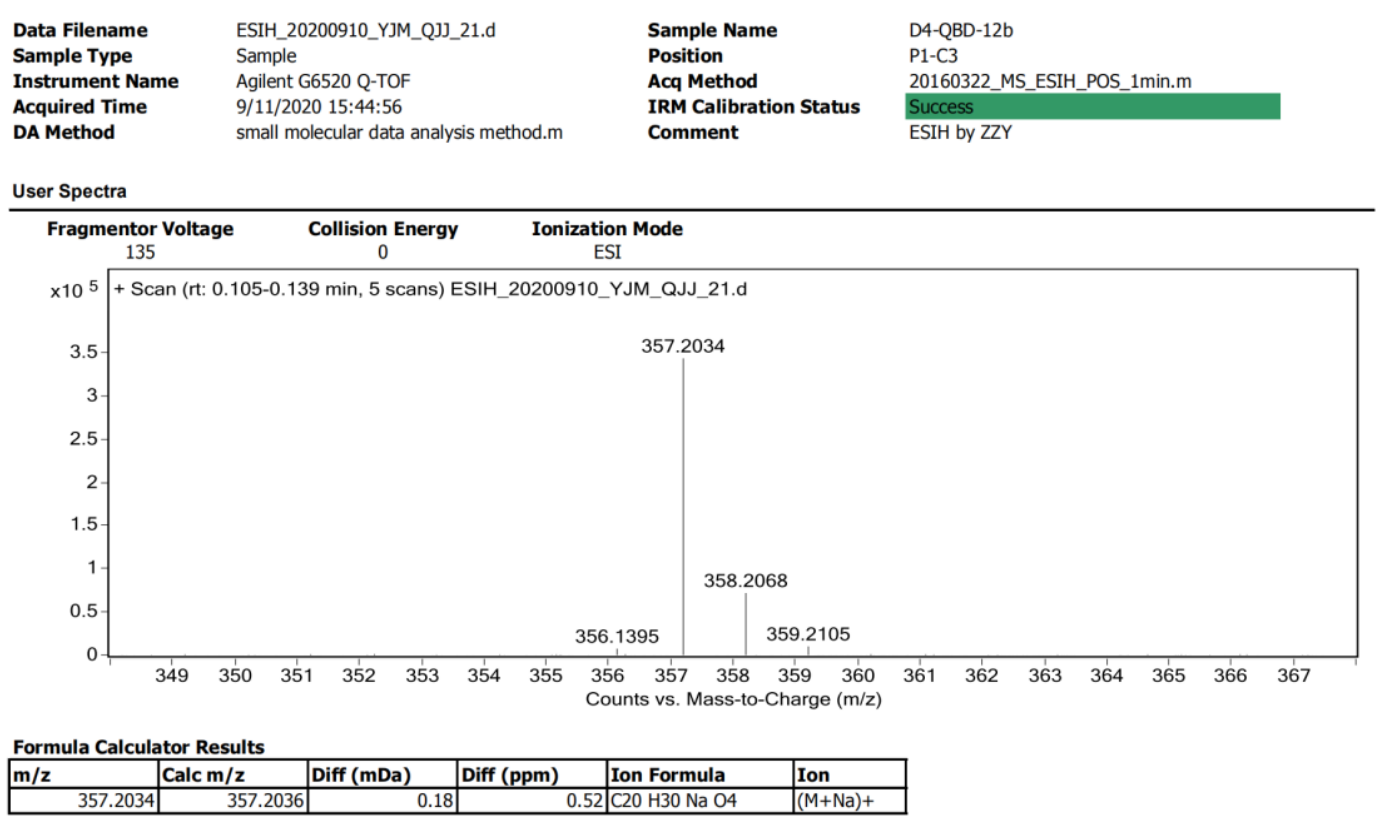

--- End Of Report --- 
Figure S42. ${ }^{1} \mathrm{H}$ NMR spectrum of sublyratin $\mathrm{F}(6)$ in $\mathrm{CDCl}_{3}$.

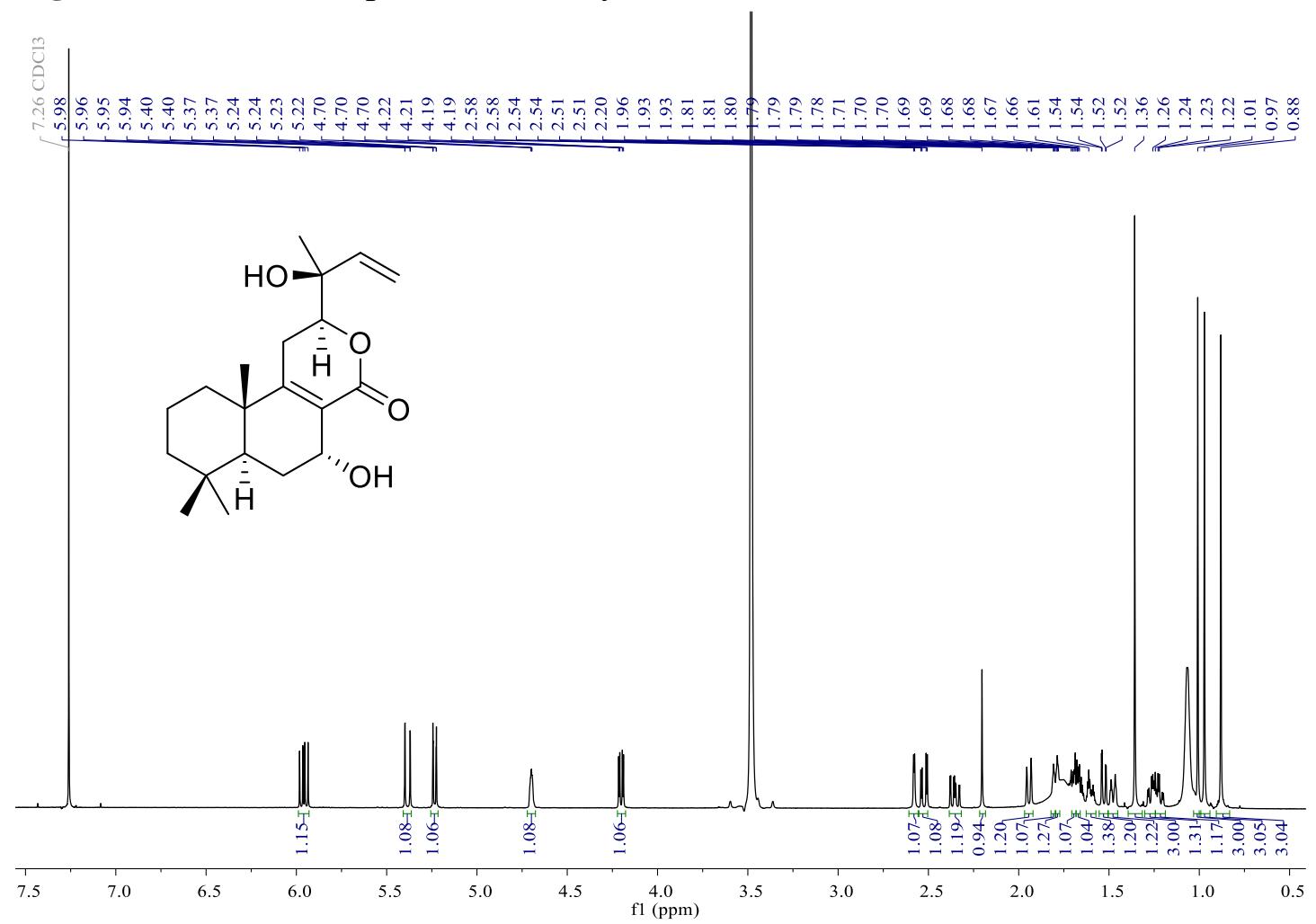

Figure S43. ${ }^{13} \mathrm{C}$ NMR spectrum of sublyratin $\mathrm{F}(6)$ in $\mathrm{CDCl}_{3}$.<smiles>C=CC(C)(O)C1CC2=C(C(=O)O1)[C@@H](O)C[C@H]1[C@@H](C)CCC[C@]21C</smiles>
$\underset{1}{3}$

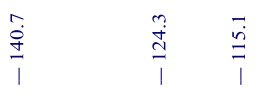

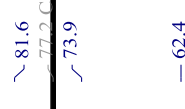

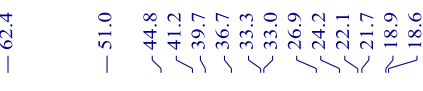

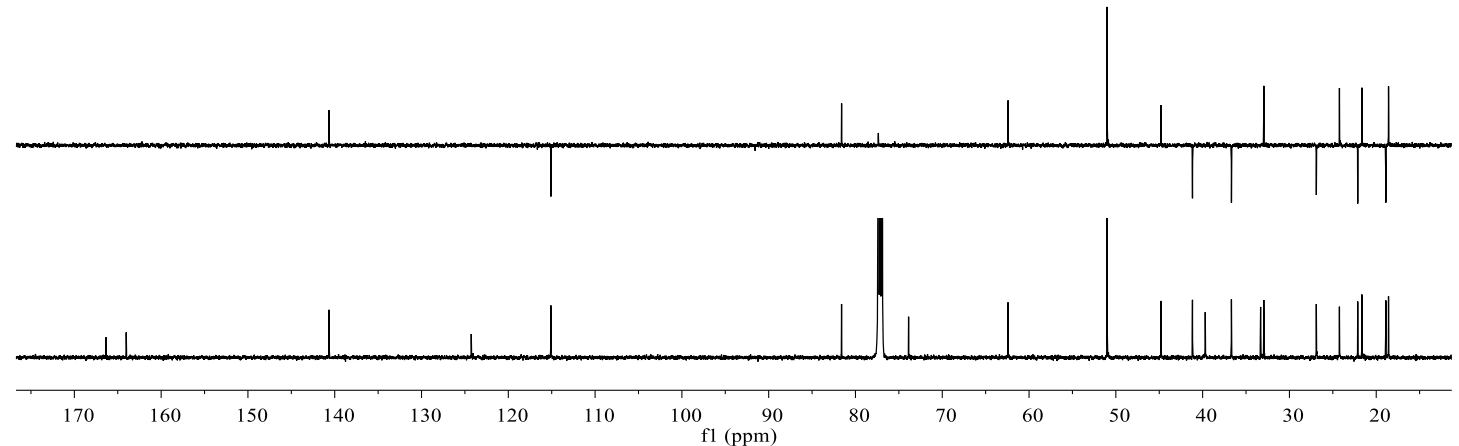


Figure S44. HSQC spectrum of sublyratin $\mathrm{F}(6)$ in $\mathrm{CDCl}_{3}$.

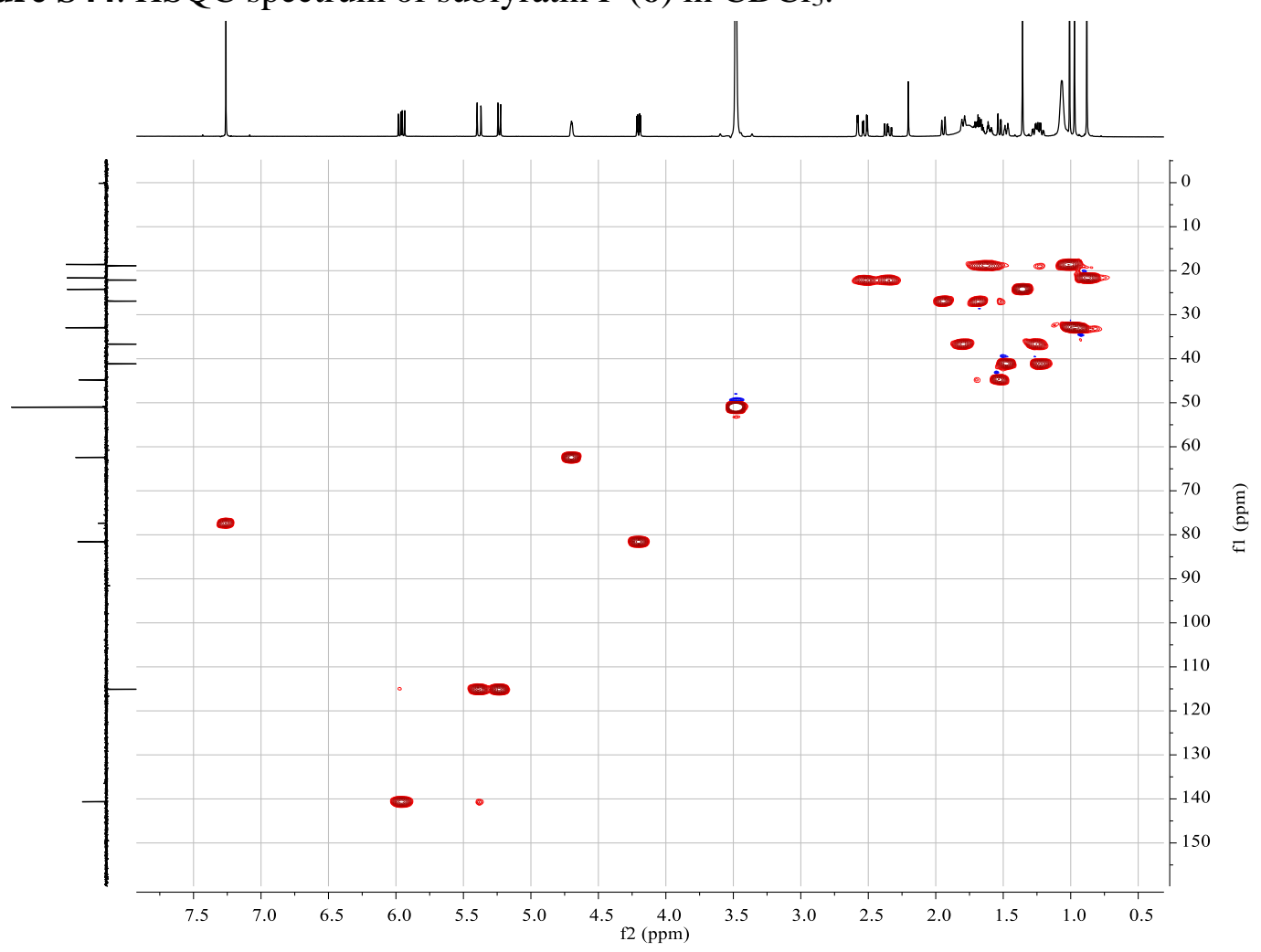

Figure S45. HMBC spectrum of sublyratin $\mathrm{F}(6)$ in $\mathrm{CDCl}_{3}$.

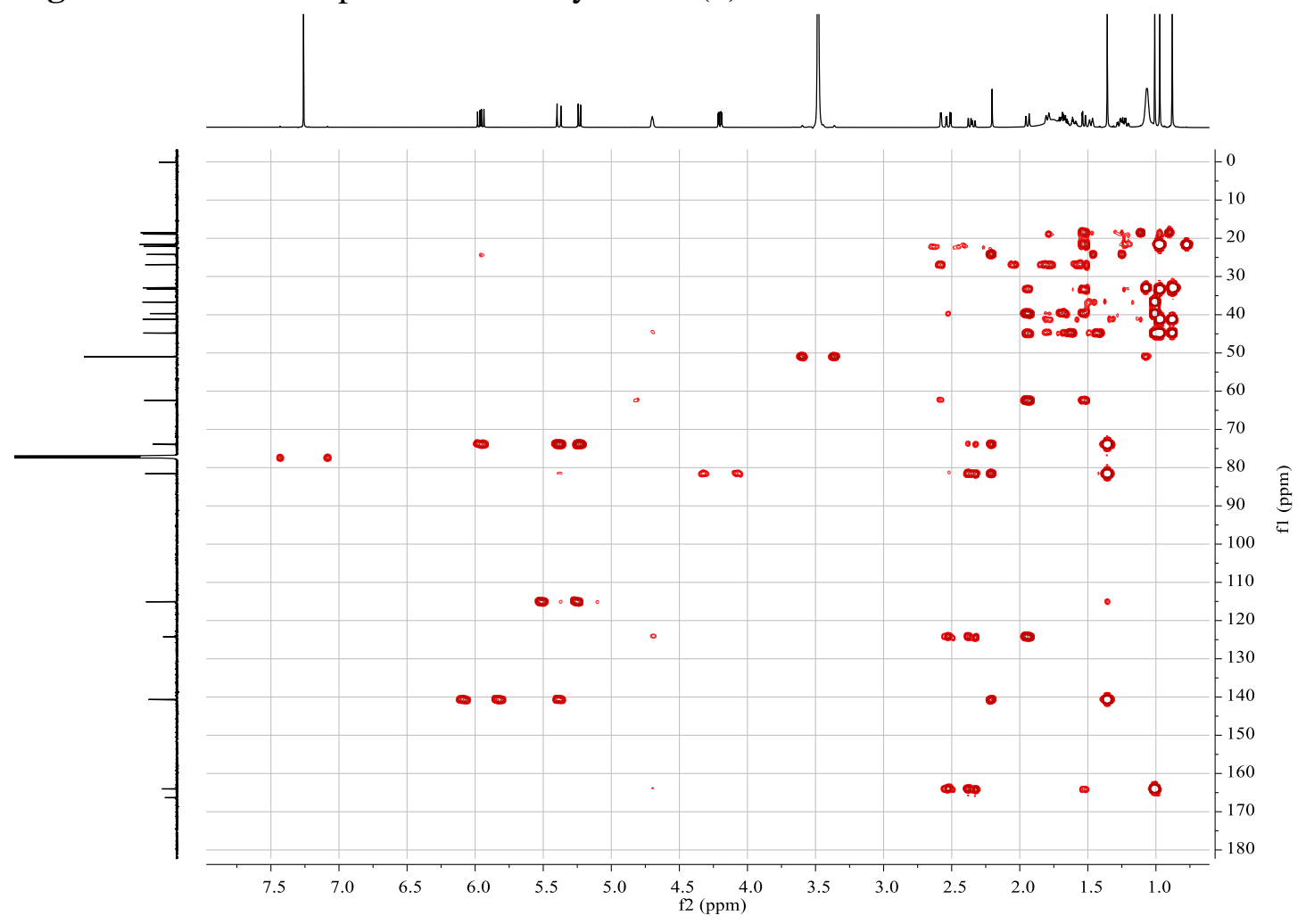


Figure S46. ${ }^{1} \mathrm{H}-{ }^{1} \mathrm{H}$ COSY spectrum of sublyratin $\mathrm{F}(\mathbf{6})$ in $\mathrm{CDCl}_{3}$.

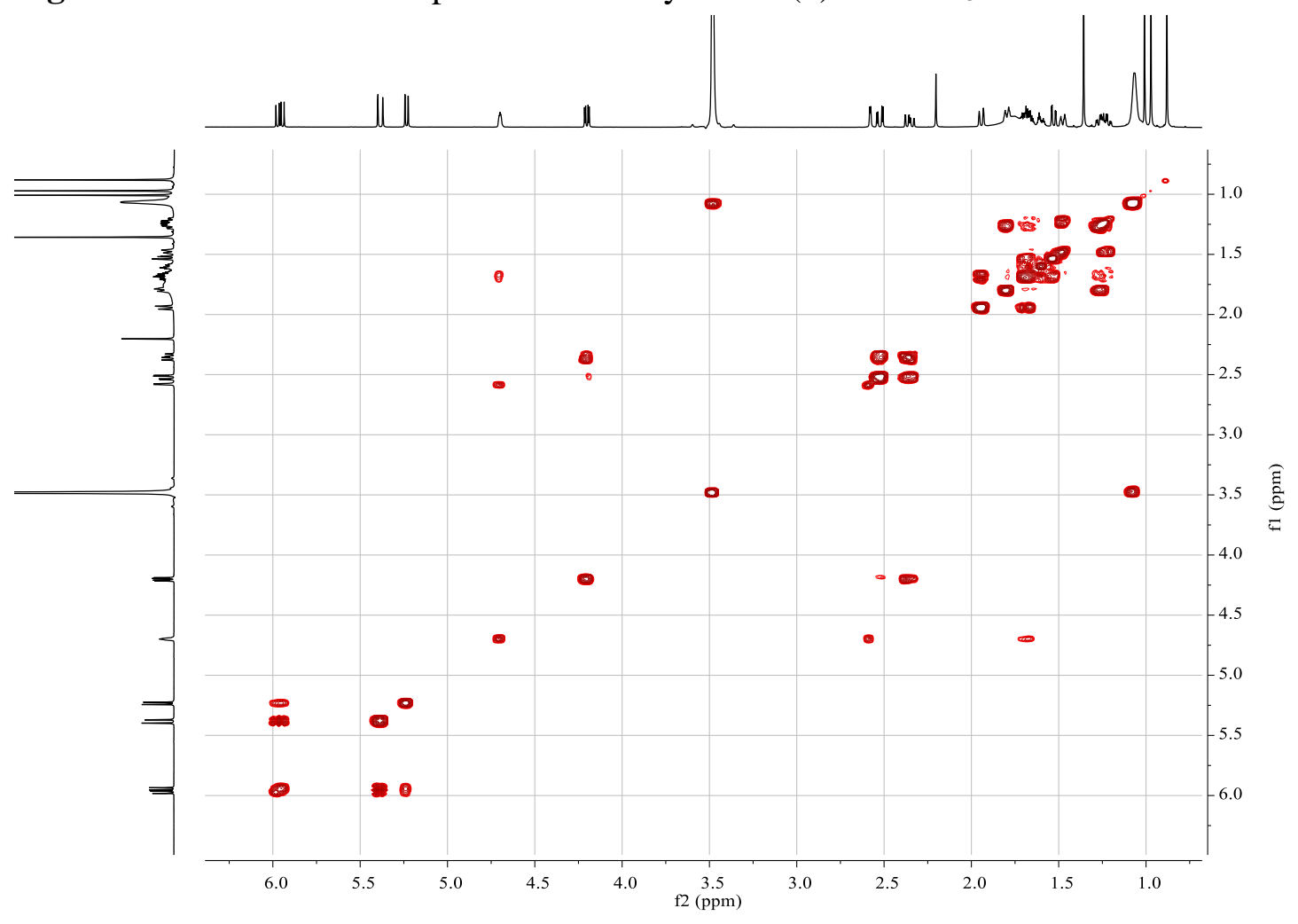

Figure S47. NOESY spectrum of sublyratin $\mathrm{F}(6)$ in $\mathrm{CDCl}_{3}$.

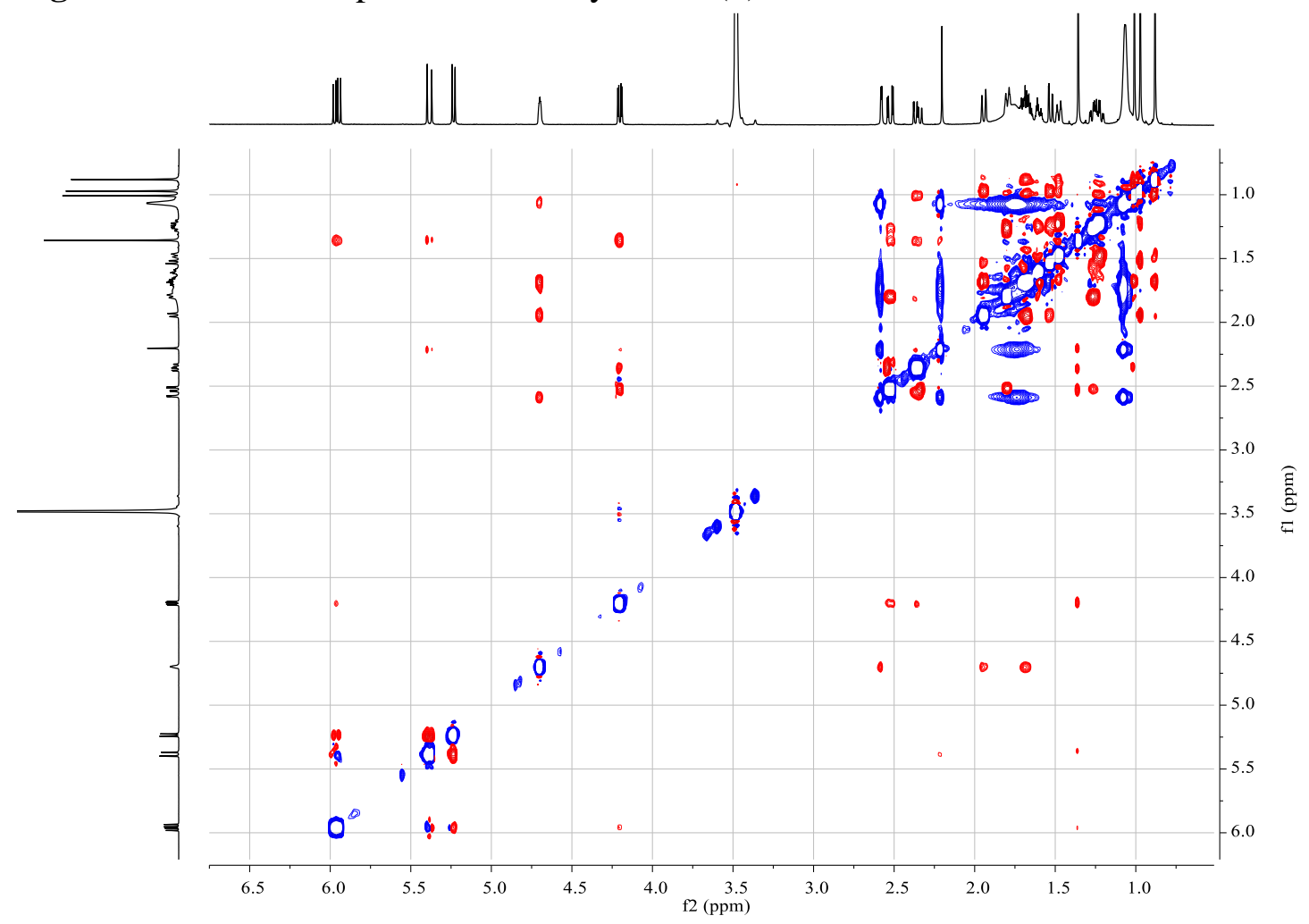


Figure S48. (+)-HRESIMS spectrum of sublyratin F (6).

Qualitative Analysis Report

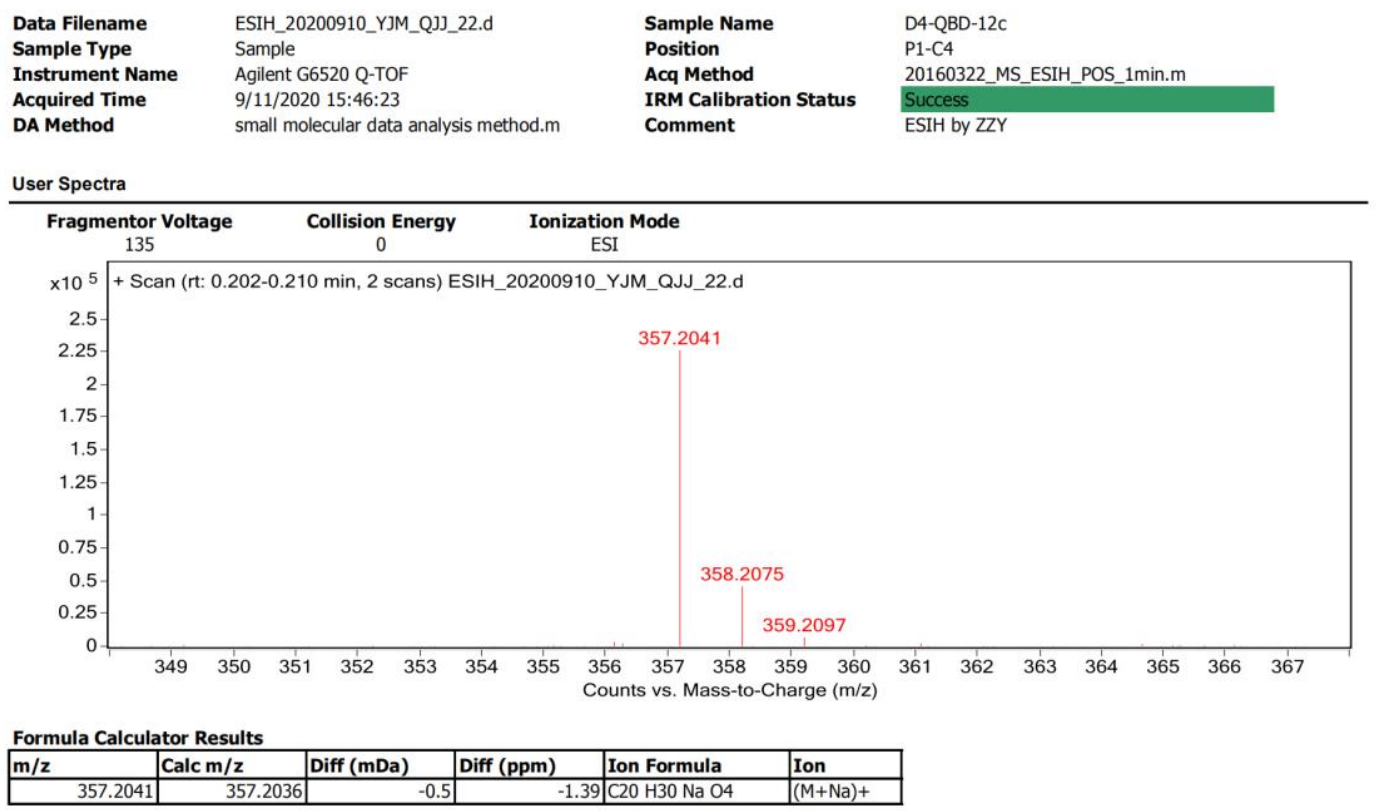

--- End Of Report --. 
Figure S49. ${ }^{1} \mathrm{H}$ NMR spectrum of sublyratin $\mathrm{G}(7)$ in $\mathrm{CDCl}_{3}$.

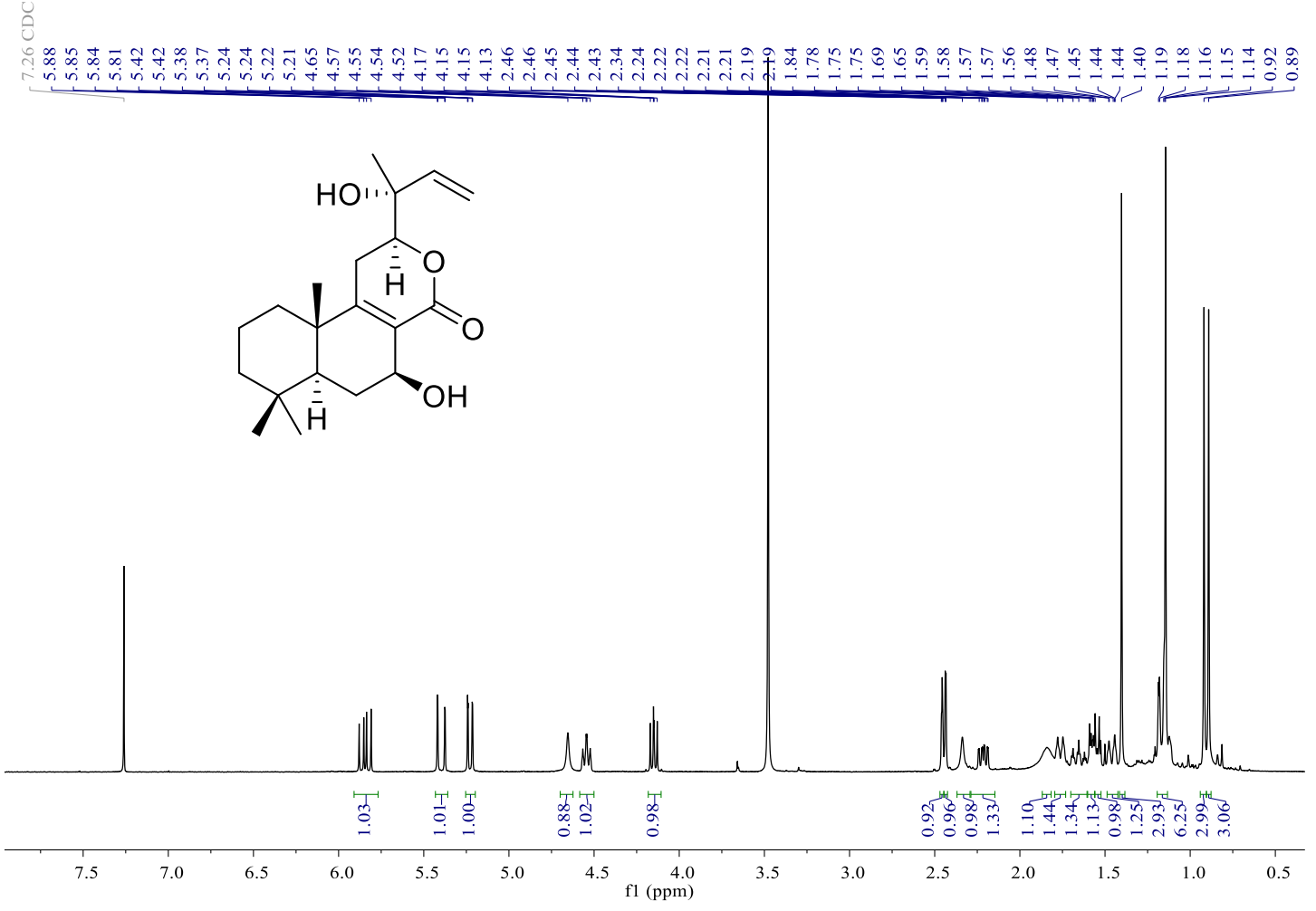

Figure S50. ${ }^{13} \mathrm{C}$ NMR spectrum of sublyratin $\mathrm{G}(7)$ in $\mathrm{CDCl}_{3}$.

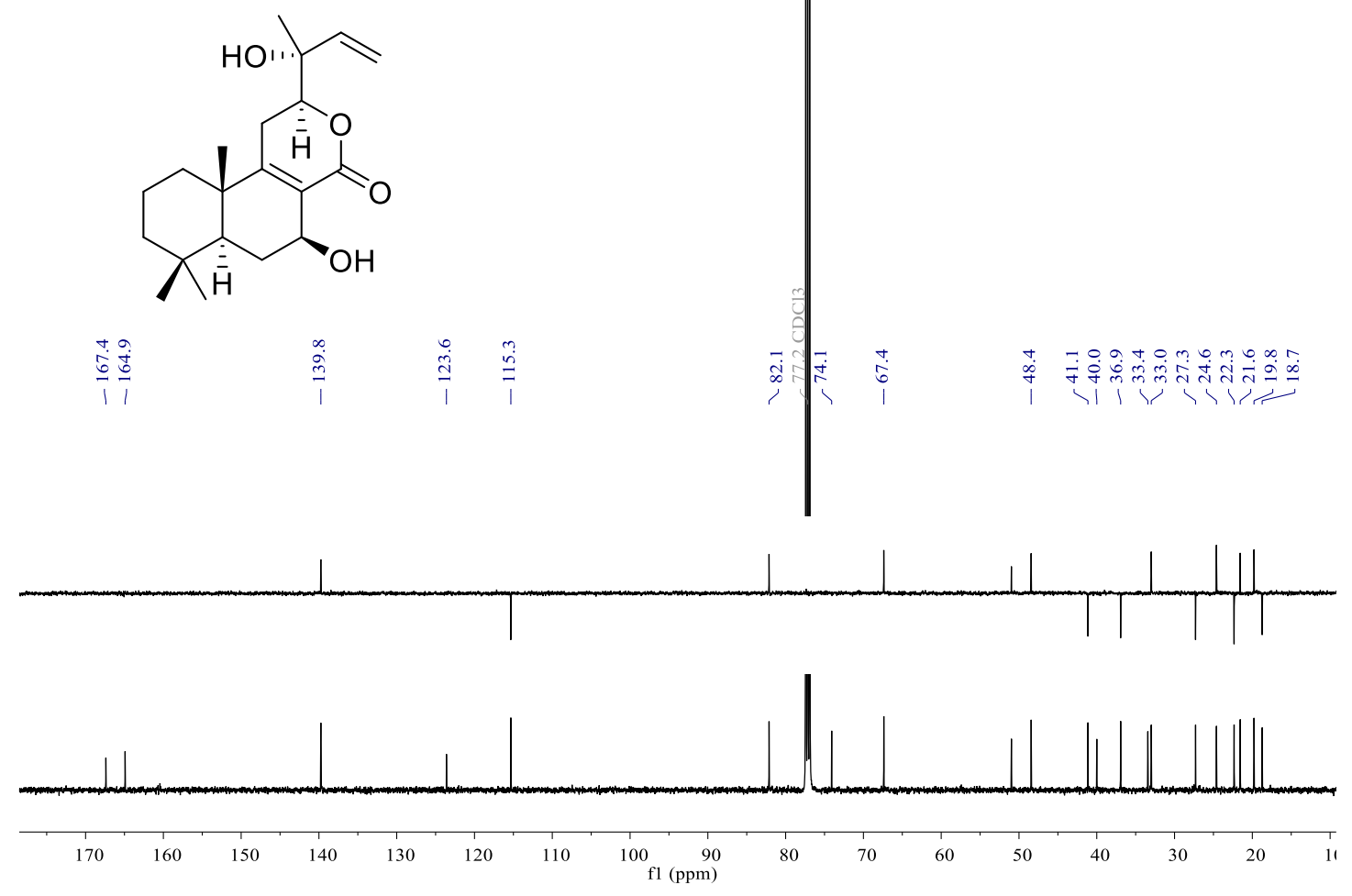


Figure S51. HSQC spectrum of sublyratin $\mathrm{G}(7)$ in $\mathrm{CDCl}_{3}$.

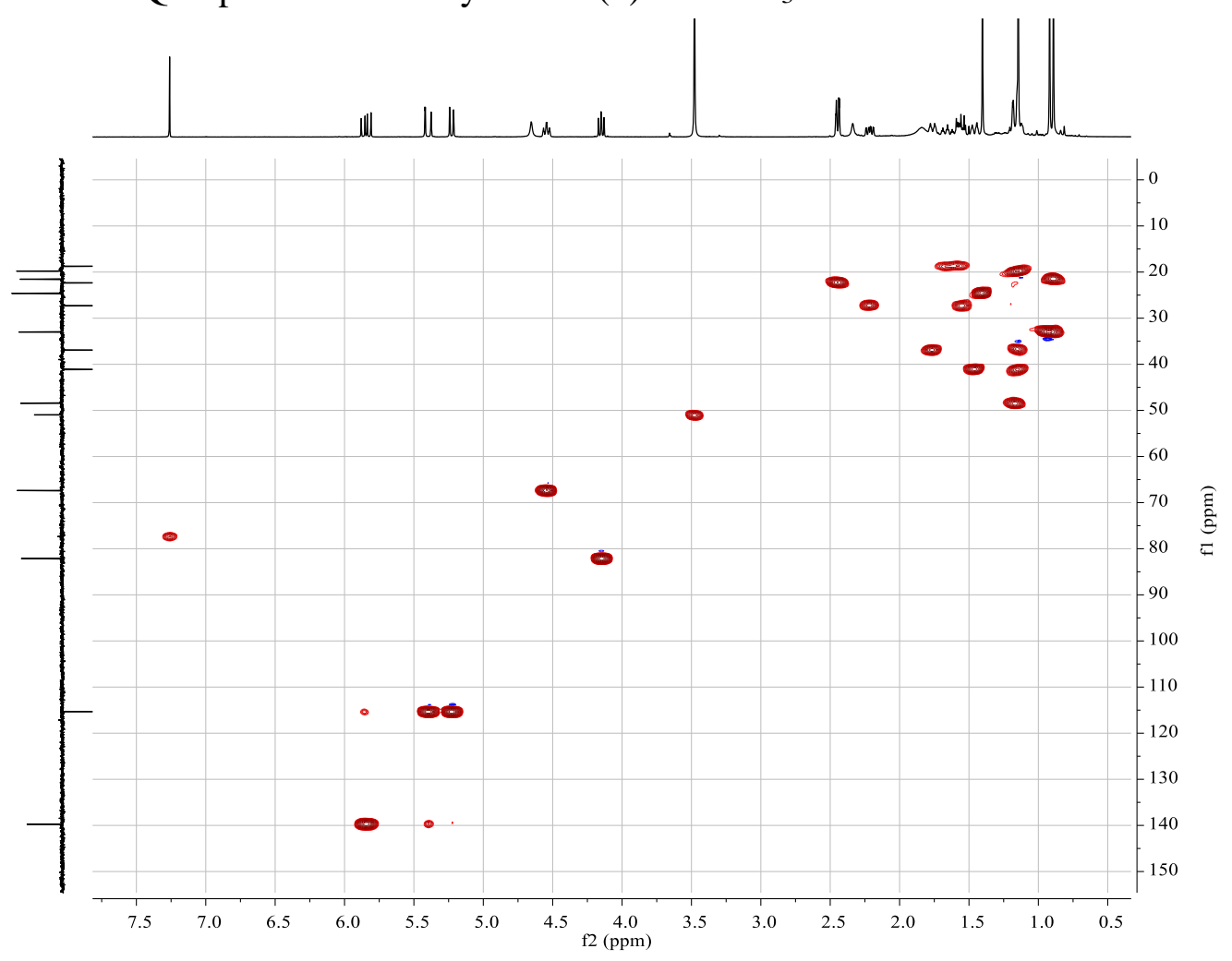

Figure S52. HMBC spectrum of sublyratin $\mathrm{G}(7)$ in $\mathrm{CDCl}_{3}$.

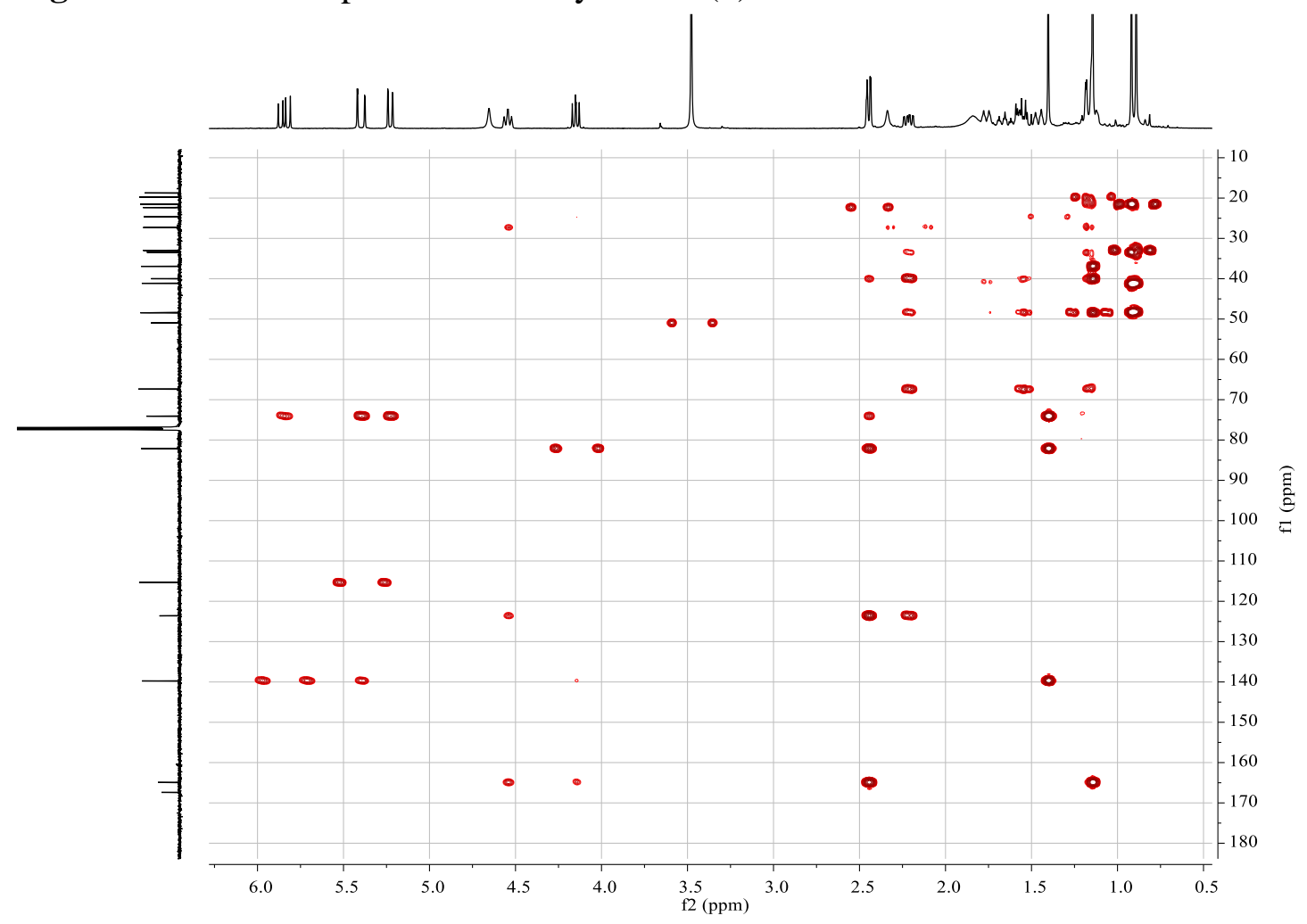


Figure S53. ${ }^{1} \mathrm{H}-{ }^{1} \mathrm{H}$ COSY spectrum of sublyratin $\mathrm{G}(7)$ in $\mathrm{CDCl}_{3}$.

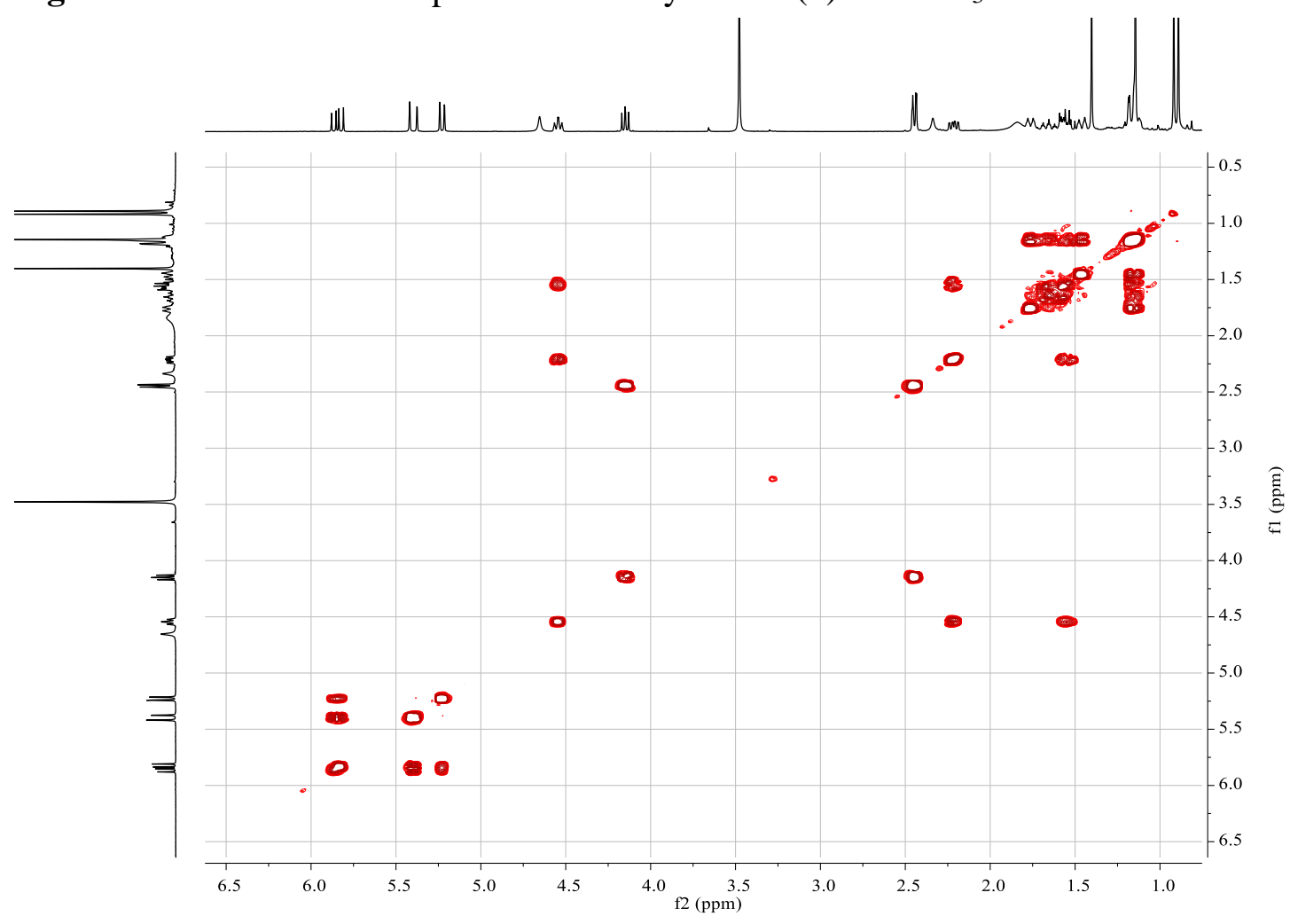

Figure S54. NOESY spectrum of sublyratin $\mathrm{G}(7)$ in $\mathrm{CDCl}_{3}$.

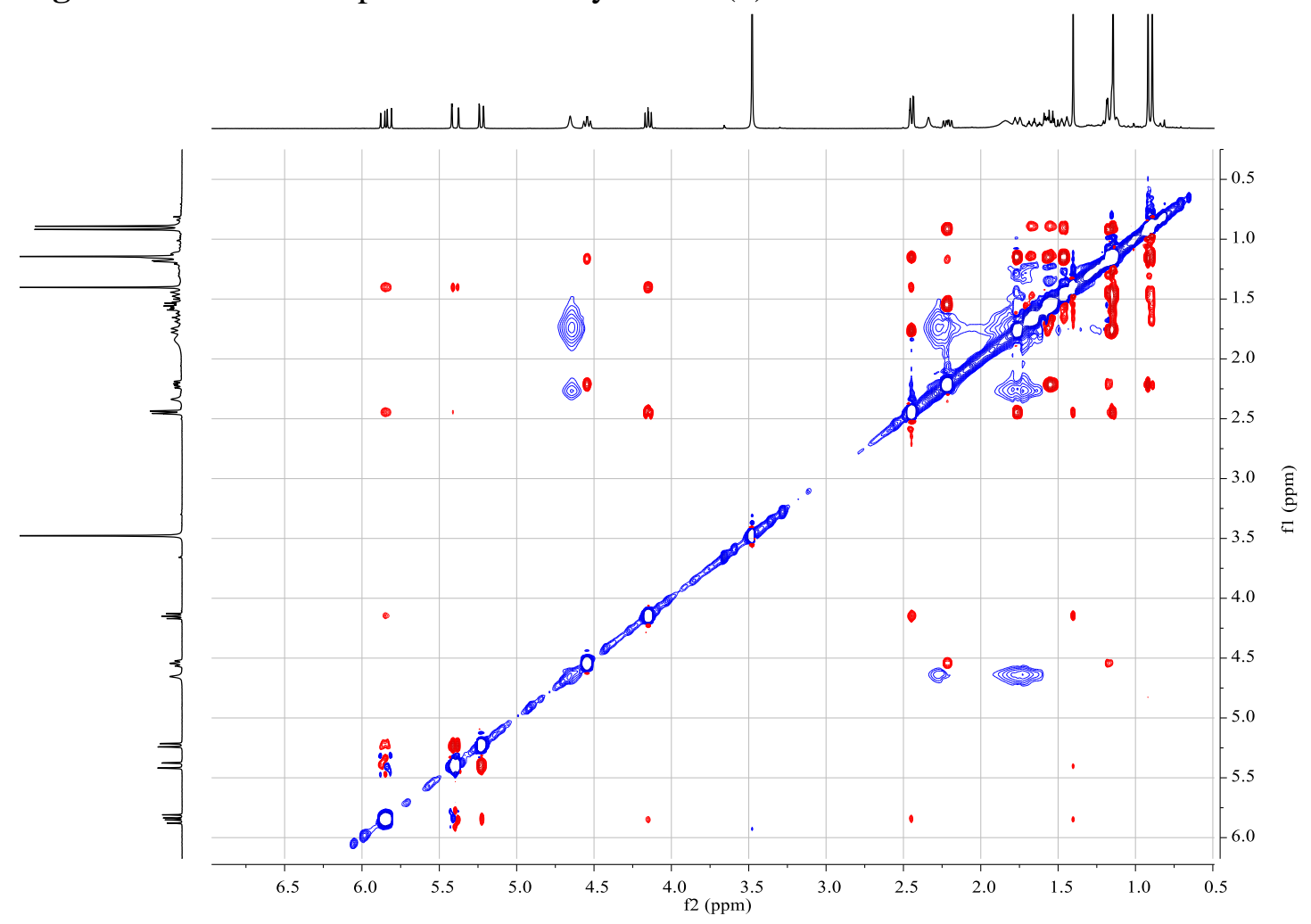


Figure S55. (+)-HRESIMS spectrum of sublyratin G (7).

\section{Qualitative Analysis Report}

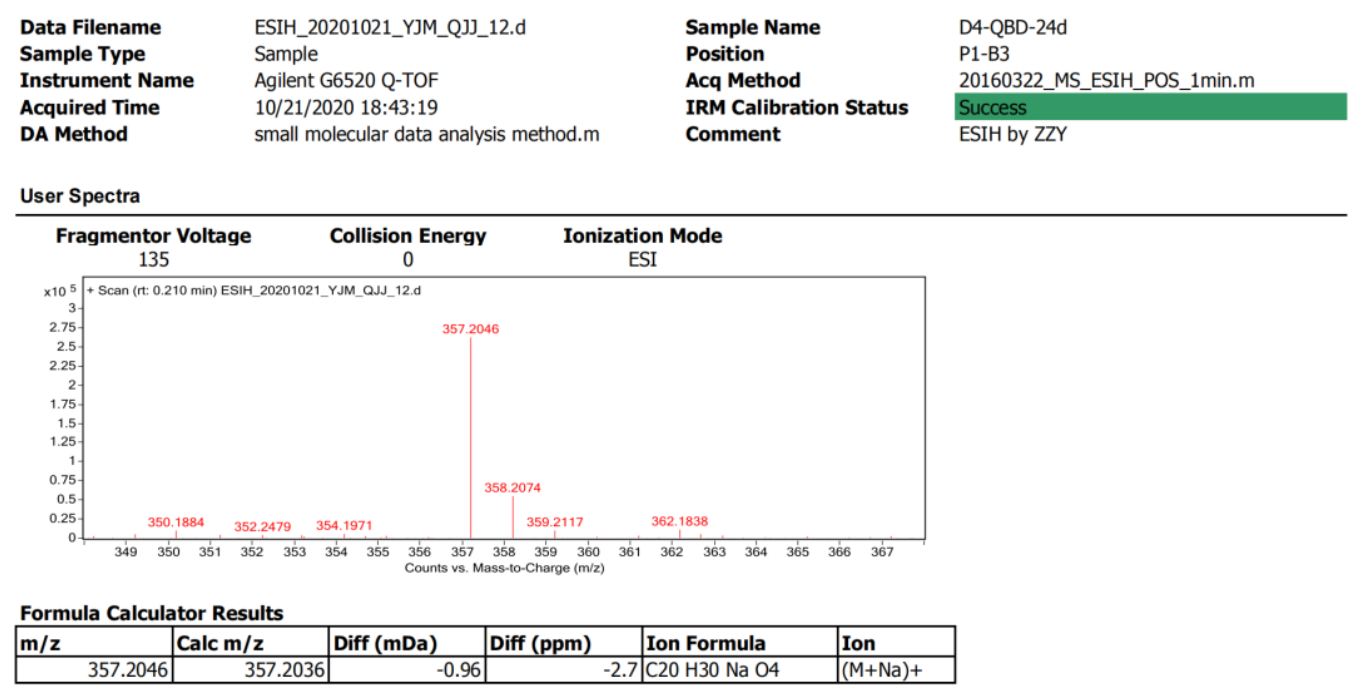

--- End Of Report --- 
Figure S56. ${ }^{1} \mathrm{H}$ NMR spectrum of sublyratin $\mathrm{H}(\mathbf{8})$ in $\mathrm{CDCl}_{3}$.

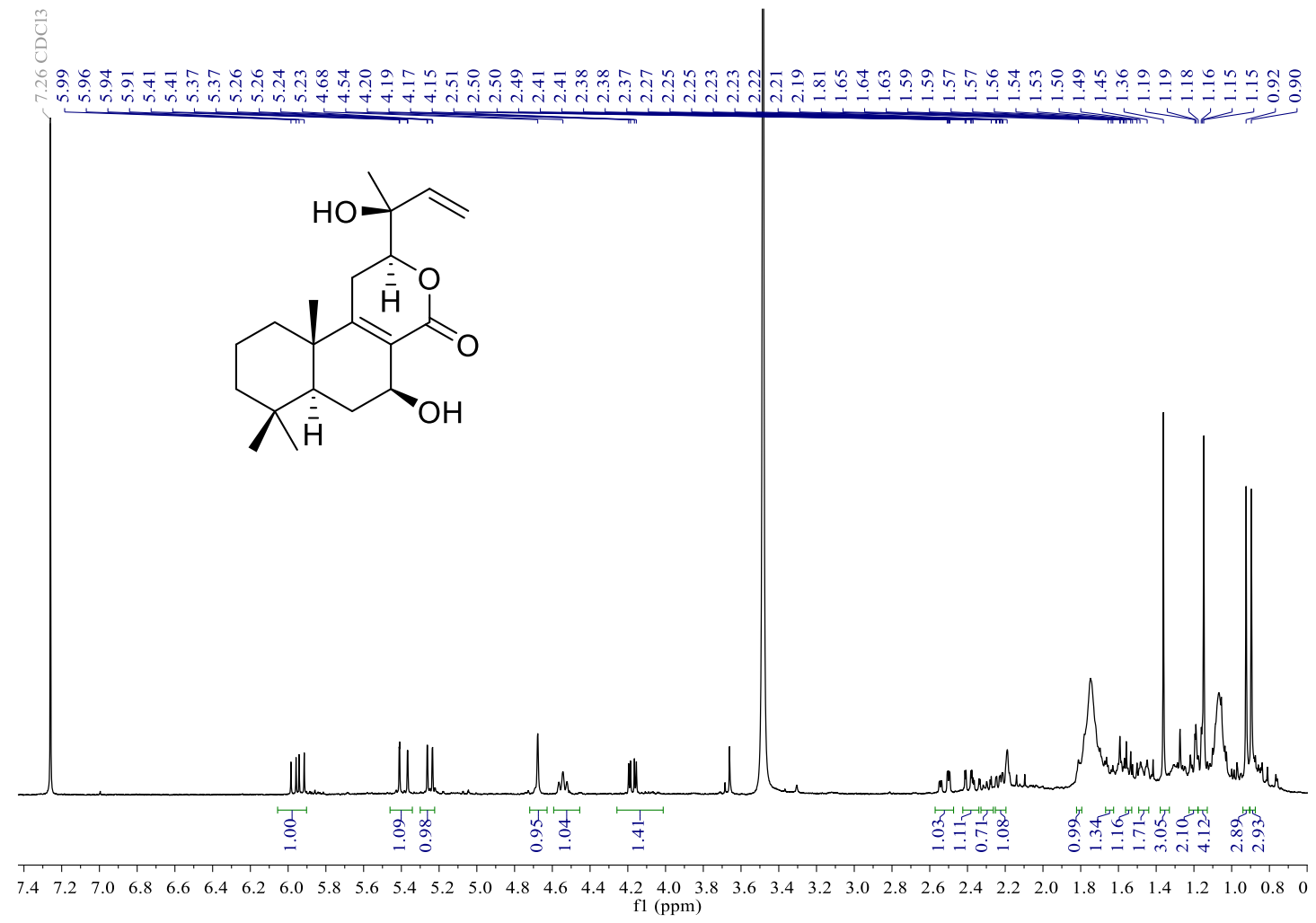

Figure S57. ${ }^{13} \mathrm{C}$ NMR spectrum of sublyratin $\mathrm{H}(\mathbf{8})$ in $\mathrm{CDCl}_{3}$.<smiles>C=CC(C)(O)C1CC2=C(C(=O)O1)C(O)CC1C(C)(C)CCC[C@]1(C)C2</smiles>

11

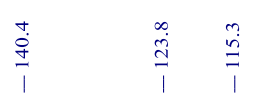

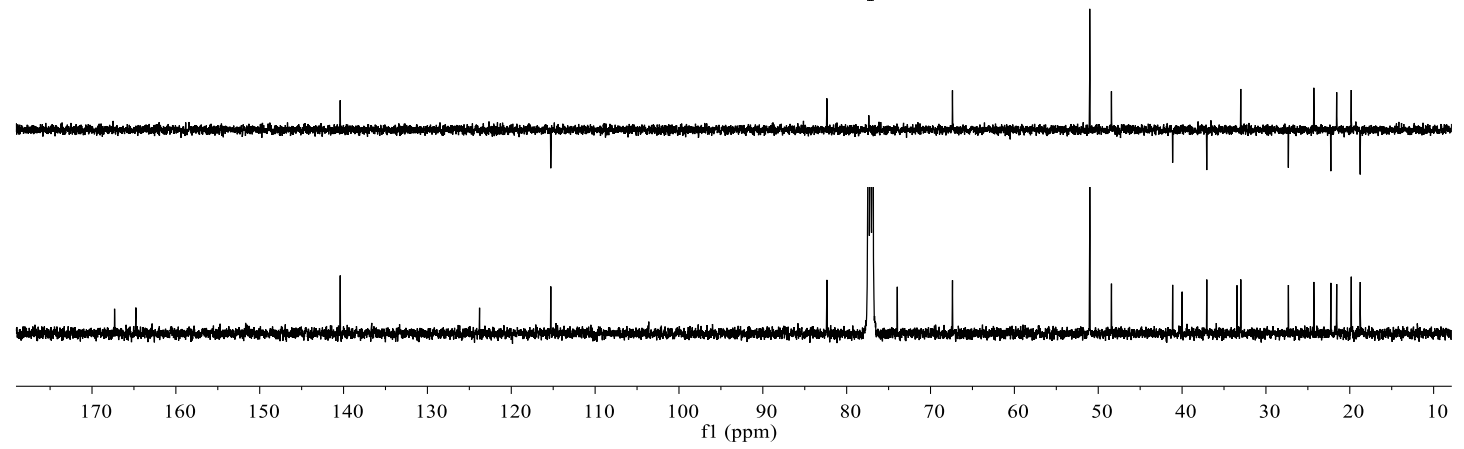


Figure S58. HSQC spectrum of sublyratin $\mathrm{H}(\mathbf{8})$ in $\mathrm{CDCl}_{3}$.

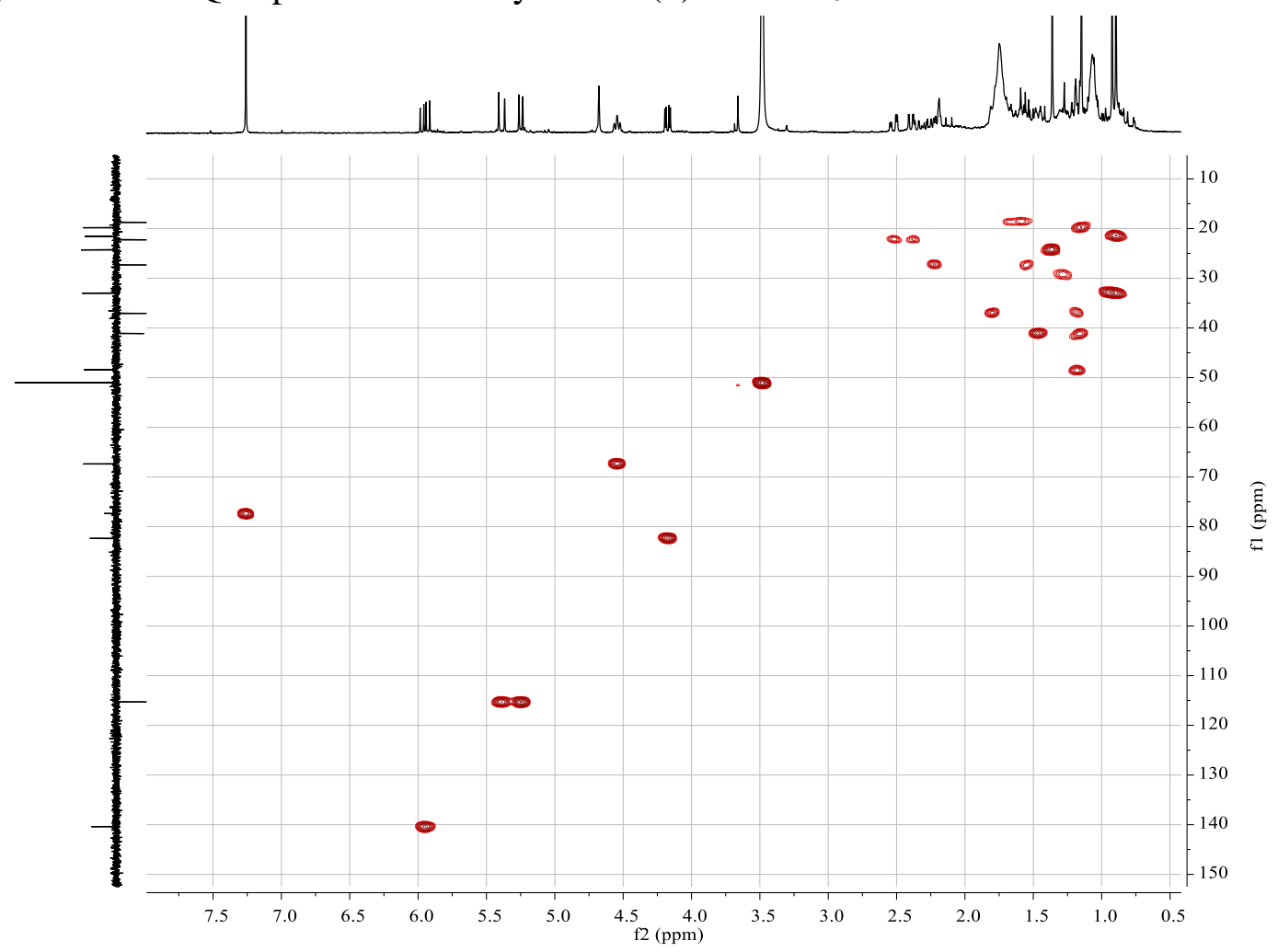

Figure S59. HMBC spectrum of sublyratin $\mathrm{H}(\mathbf{8})$ in $\mathrm{CDCl}_{3}$.

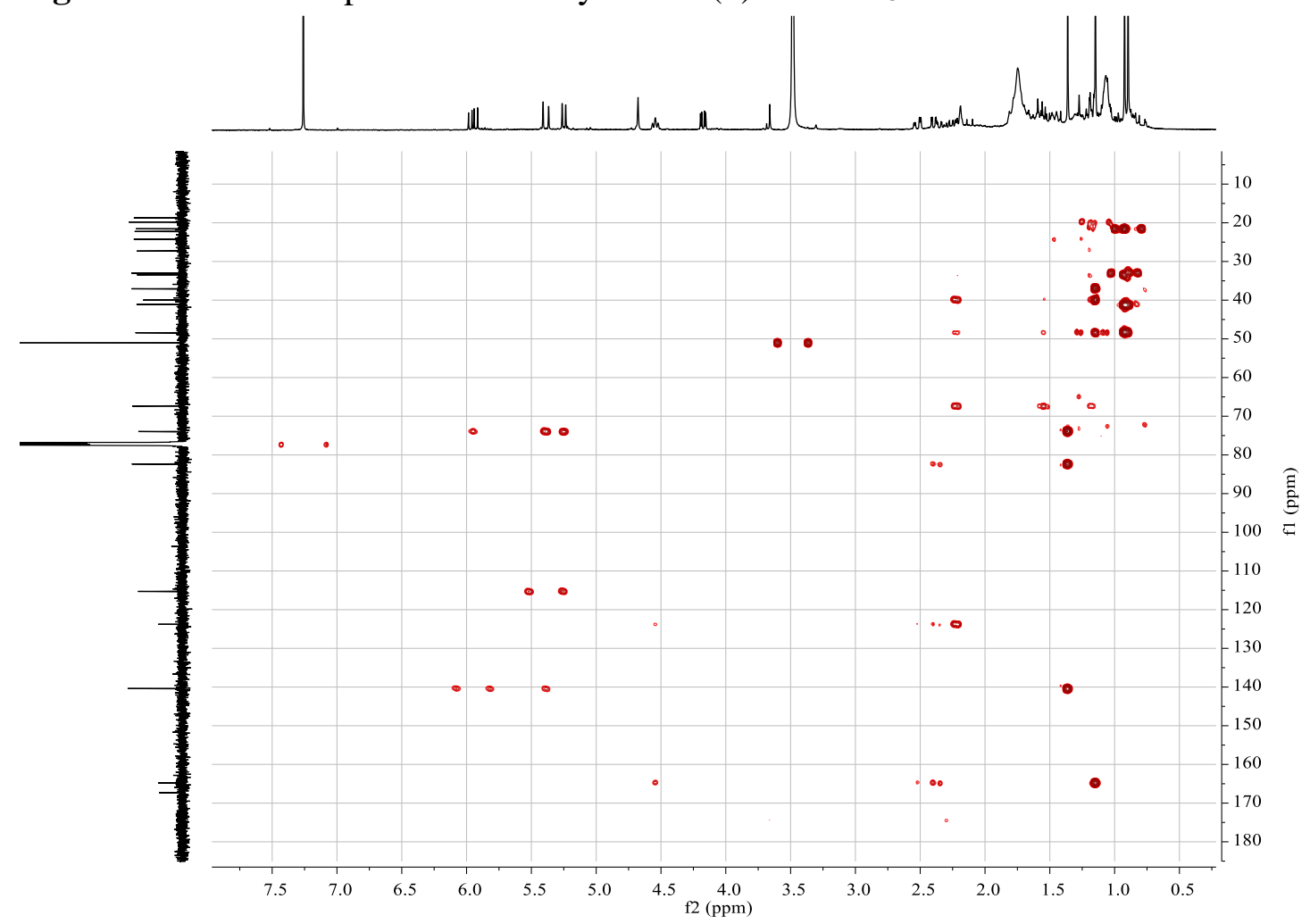

41 
Figure S60. ${ }^{1} \mathrm{H}-{ }^{1} \mathrm{H}$ COSY spectrum of sublyratin $\mathrm{H}(\mathbf{8})$ in $\mathrm{CDCl}_{3}$.

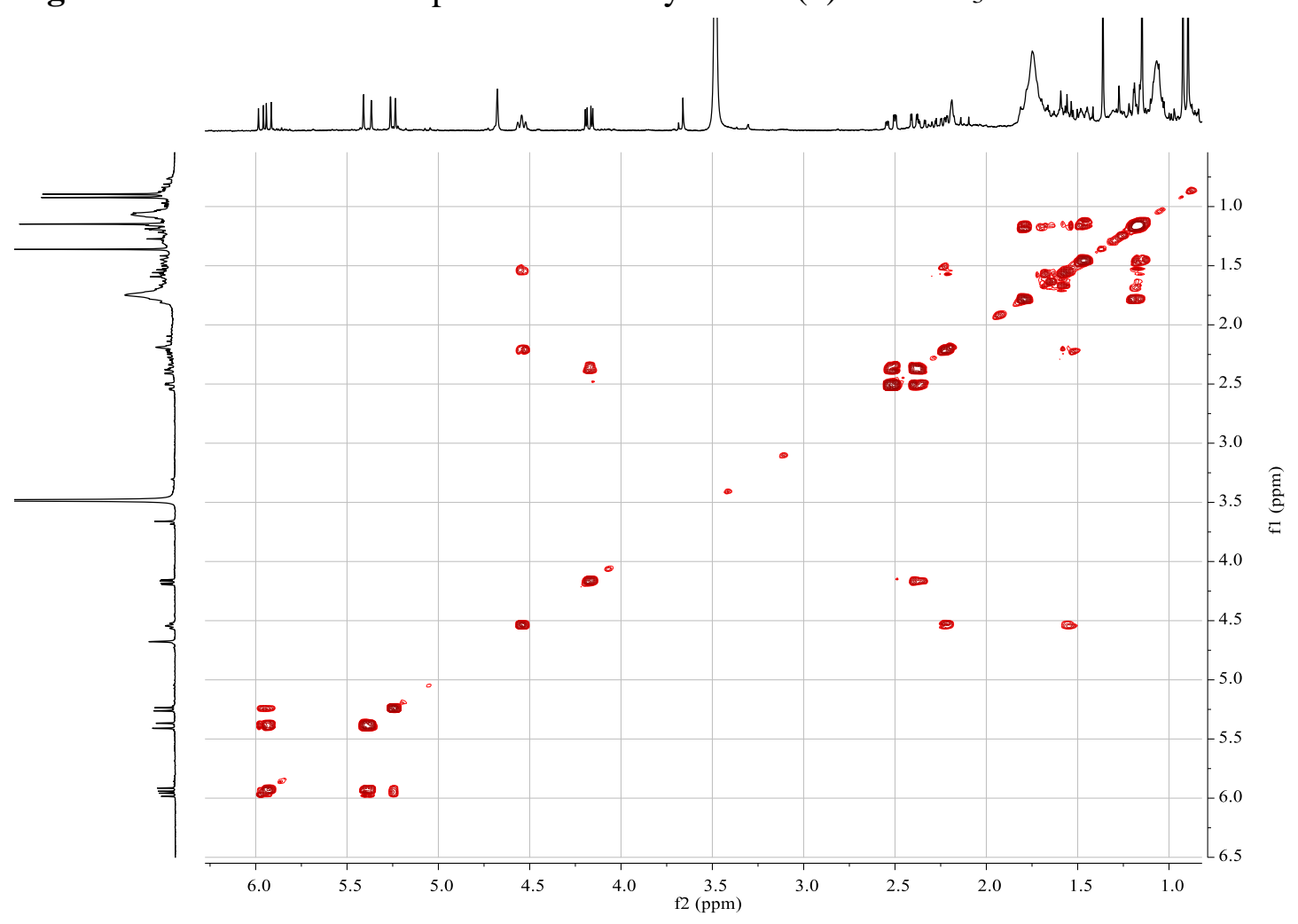

Figure S61. NOESY spectrum of sublyratin $\mathrm{H}(8)$ in $\mathrm{CDCl}_{3}$.

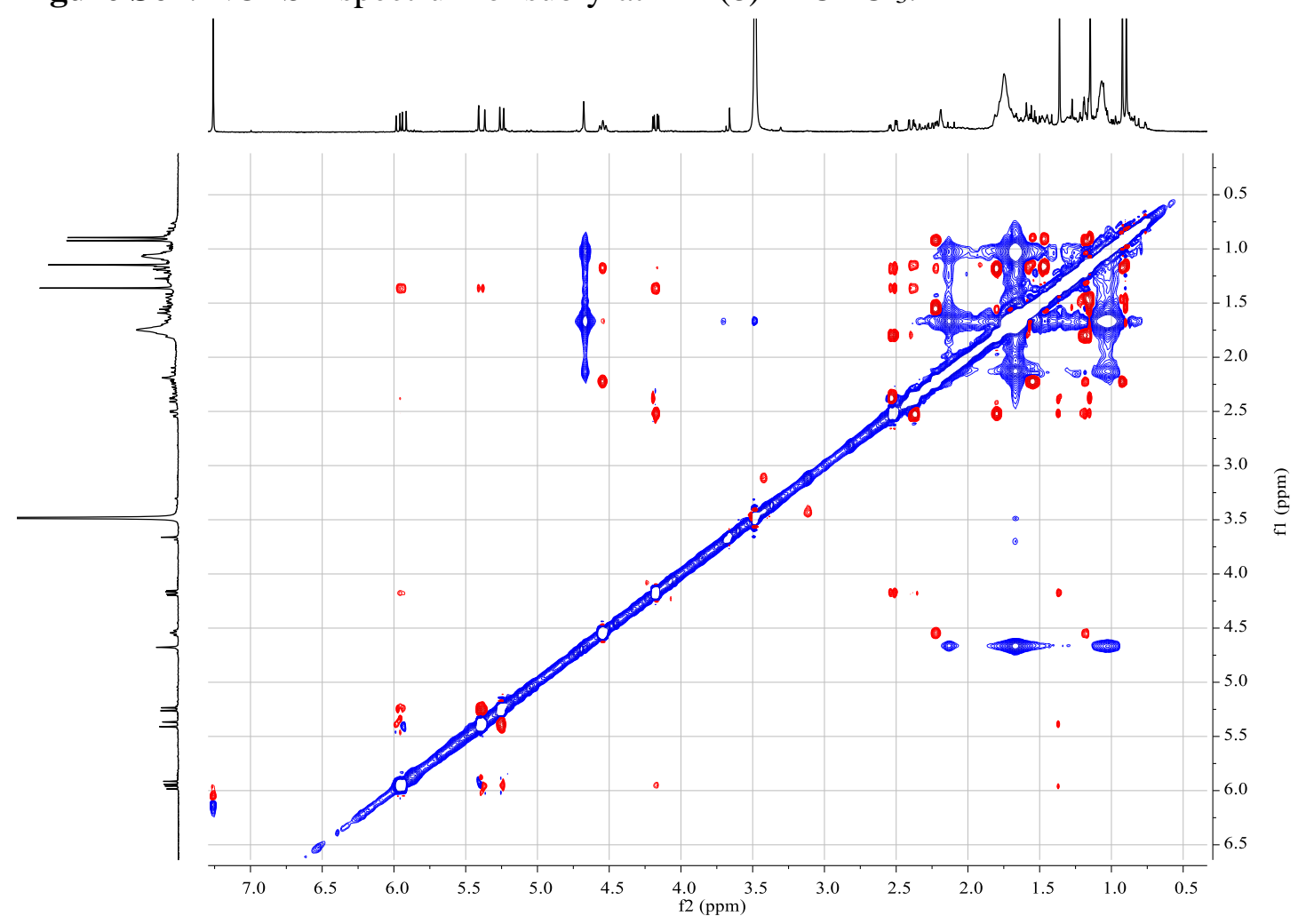


Figure S62. (+)-HRESIMS spectrum of sublyratin H (8).

Qualitative Analysis Report

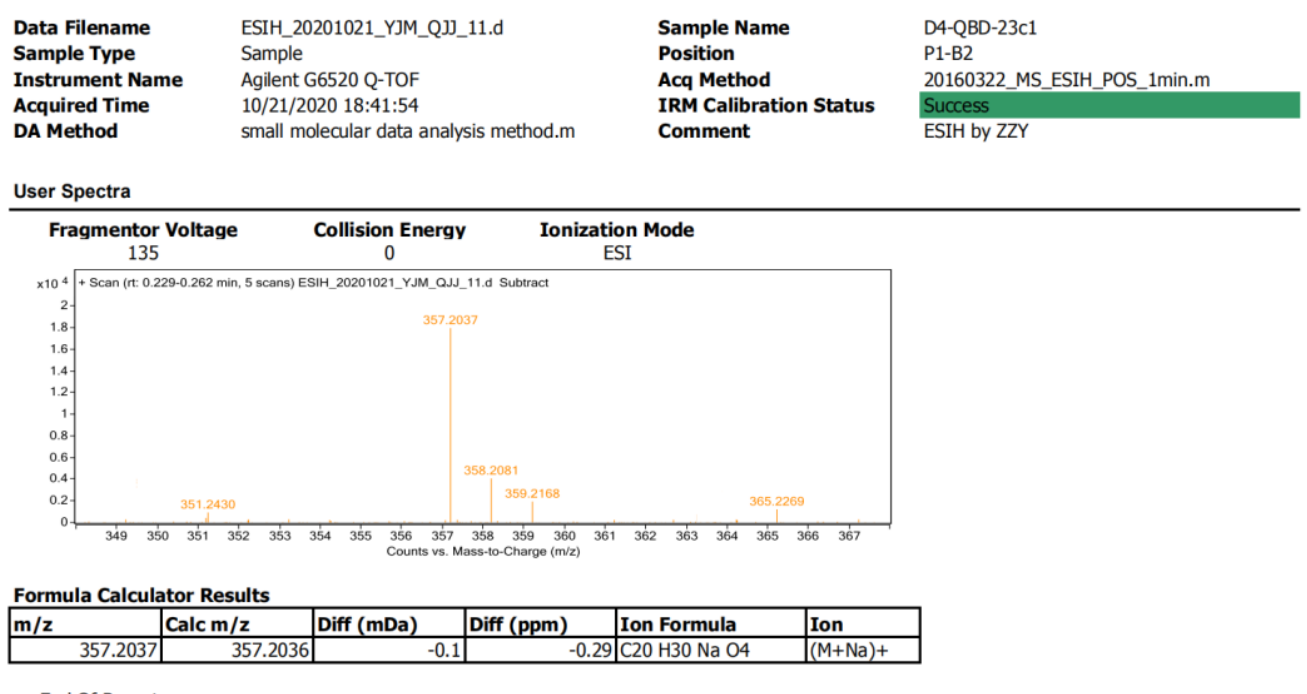

--- End Of Report --- 
Figure S63. ${ }^{1} \mathrm{H}$ NMR spectrum of sublyratin I (9) in $\mathrm{CDCl}_{3}$.

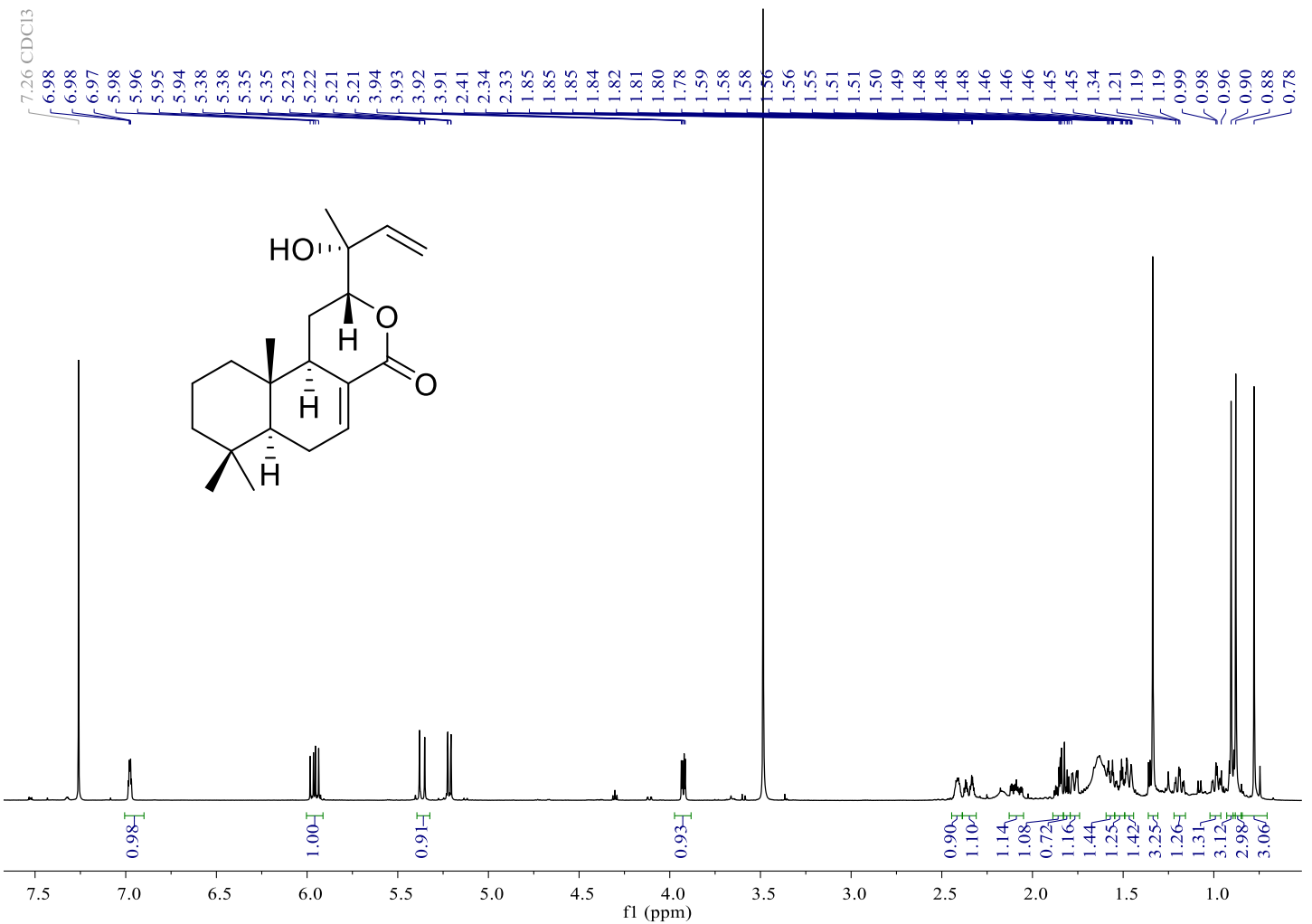

Figure S64. ${ }^{13} \mathrm{C}$ NMR spectrum of sublyratin $\mathrm{I}(9)$ in $\mathrm{CDCl}_{3}$.
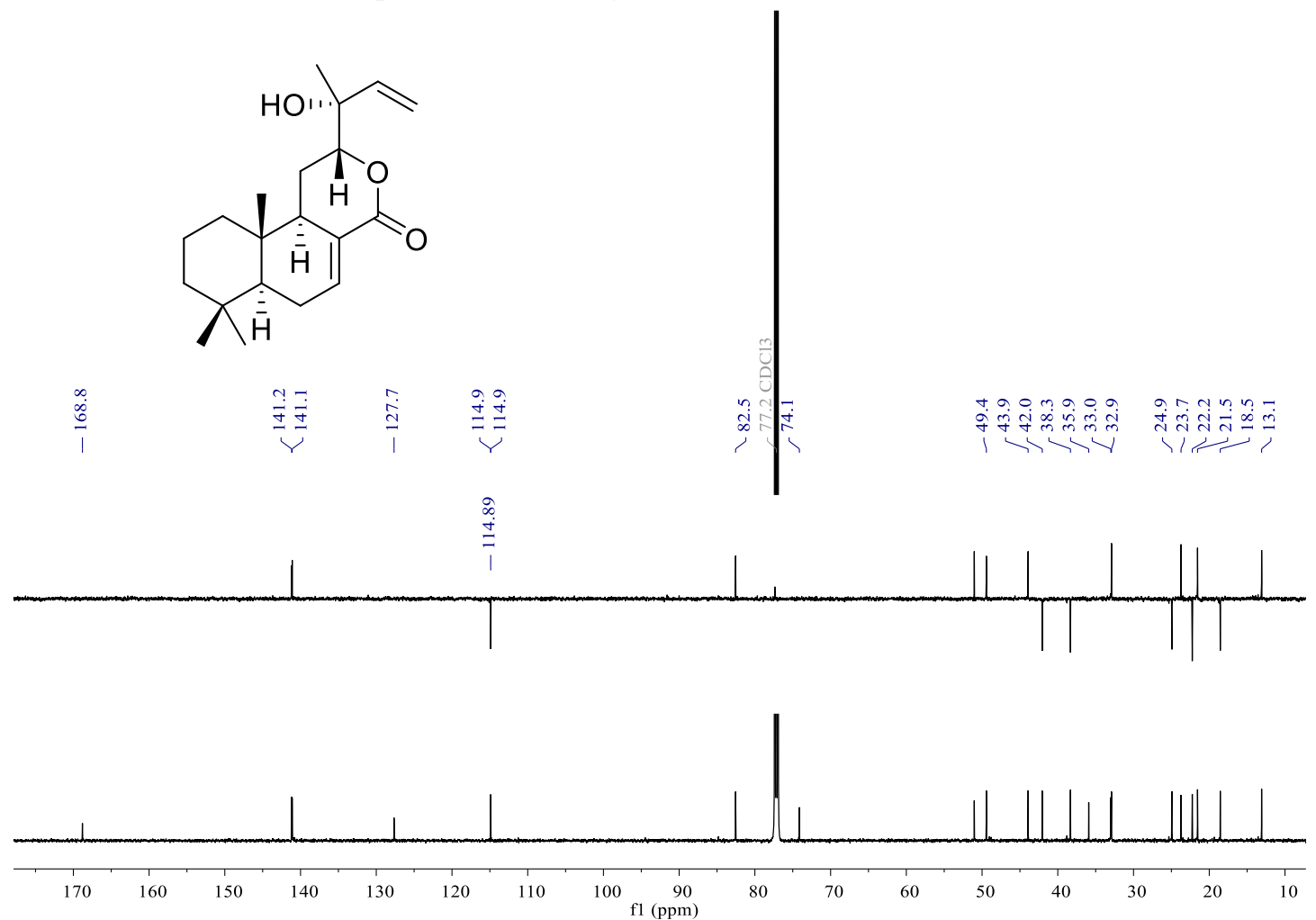
Figure S65. HSQC spectrum of sublyratin I (9) in $\mathrm{CDCl}_{3}$.

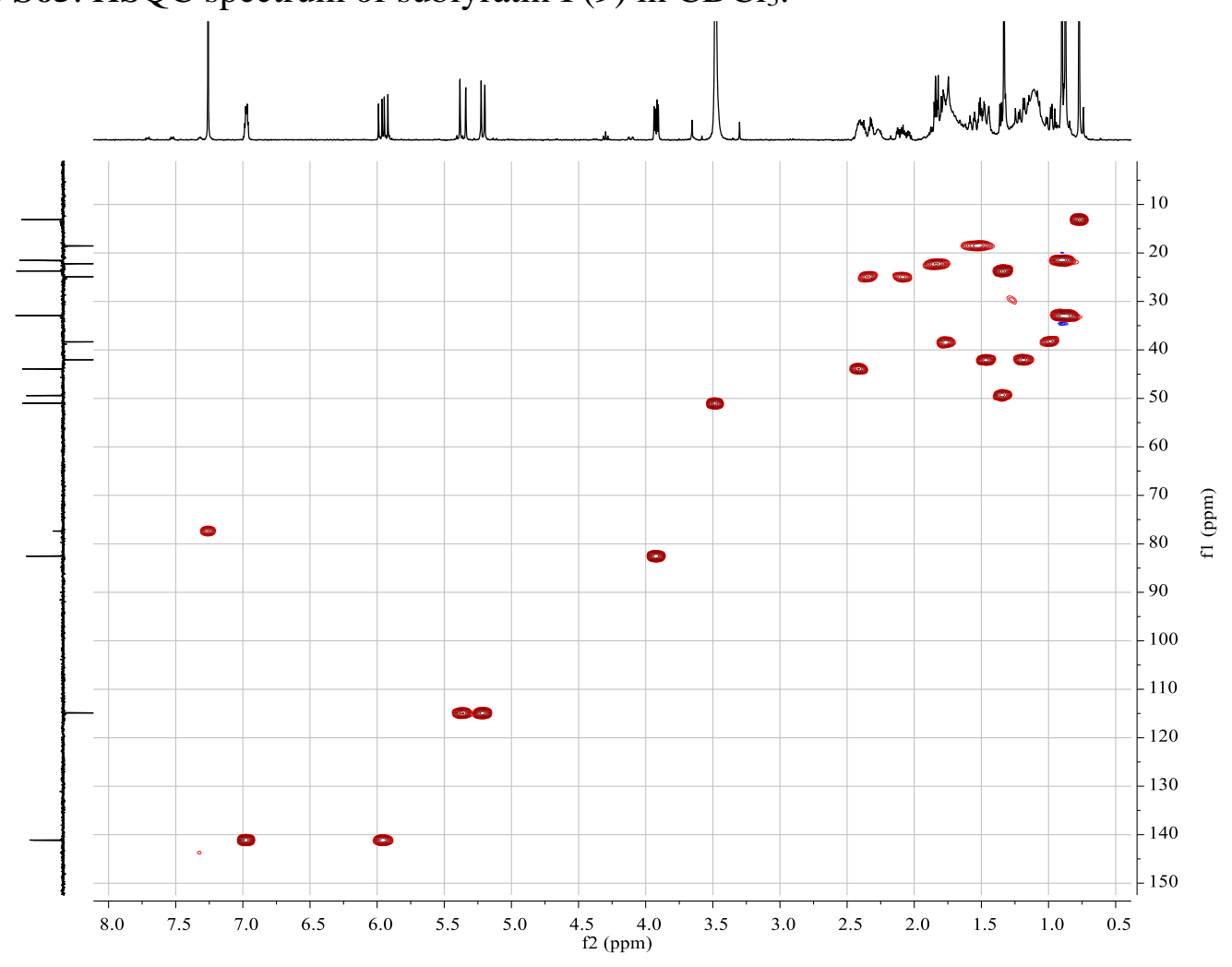

Figure S66. HMBC spectrum of sublyratin I (9) in $\mathrm{CDCl}_{3}$.

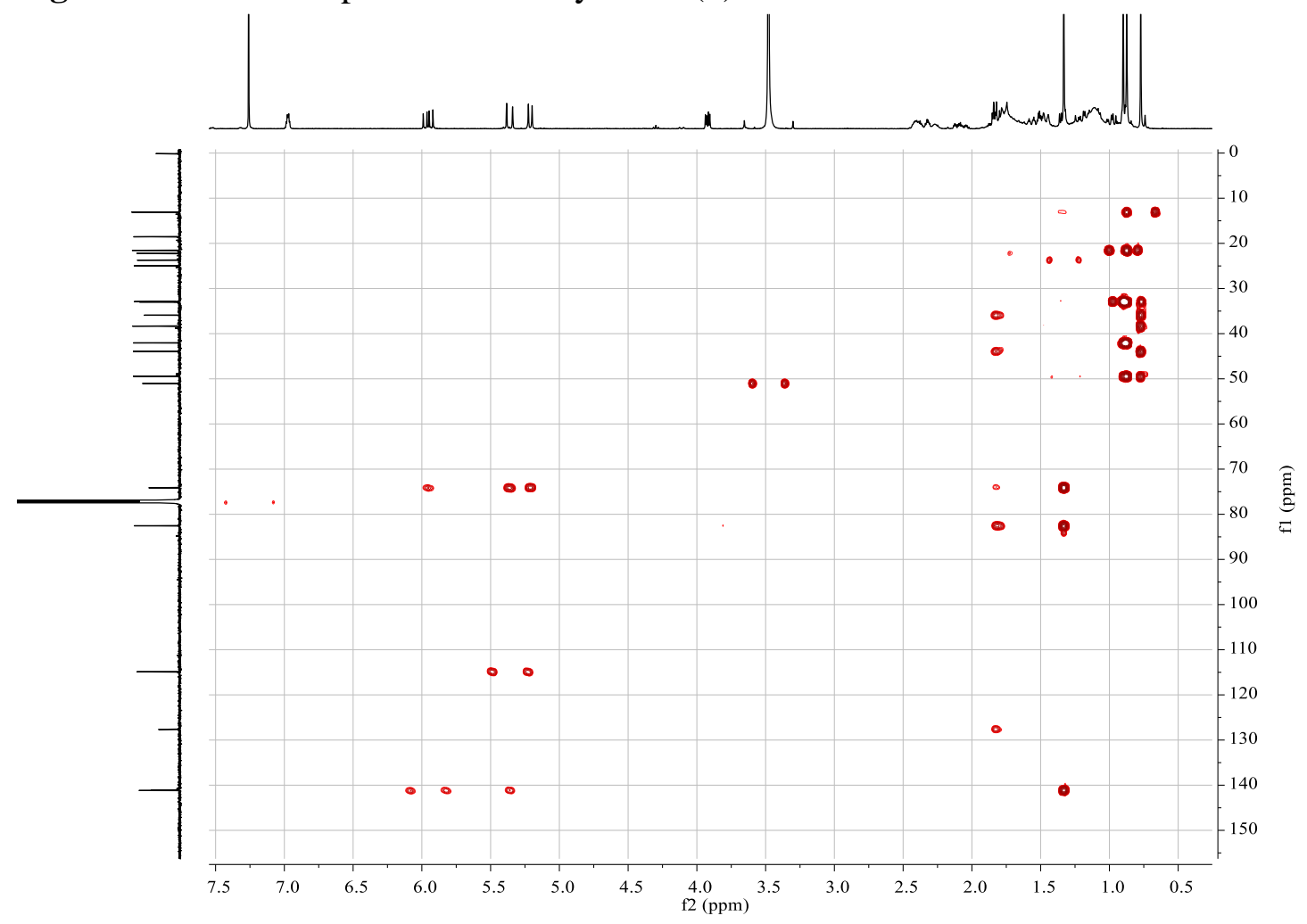


Figure S67. ${ }^{1} \mathrm{H}-{ }^{1} \mathrm{H}$ COSY spectrum of sublyratin $\mathrm{I}(\mathbf{9})$ in $\mathrm{CDCl}_{3}$.

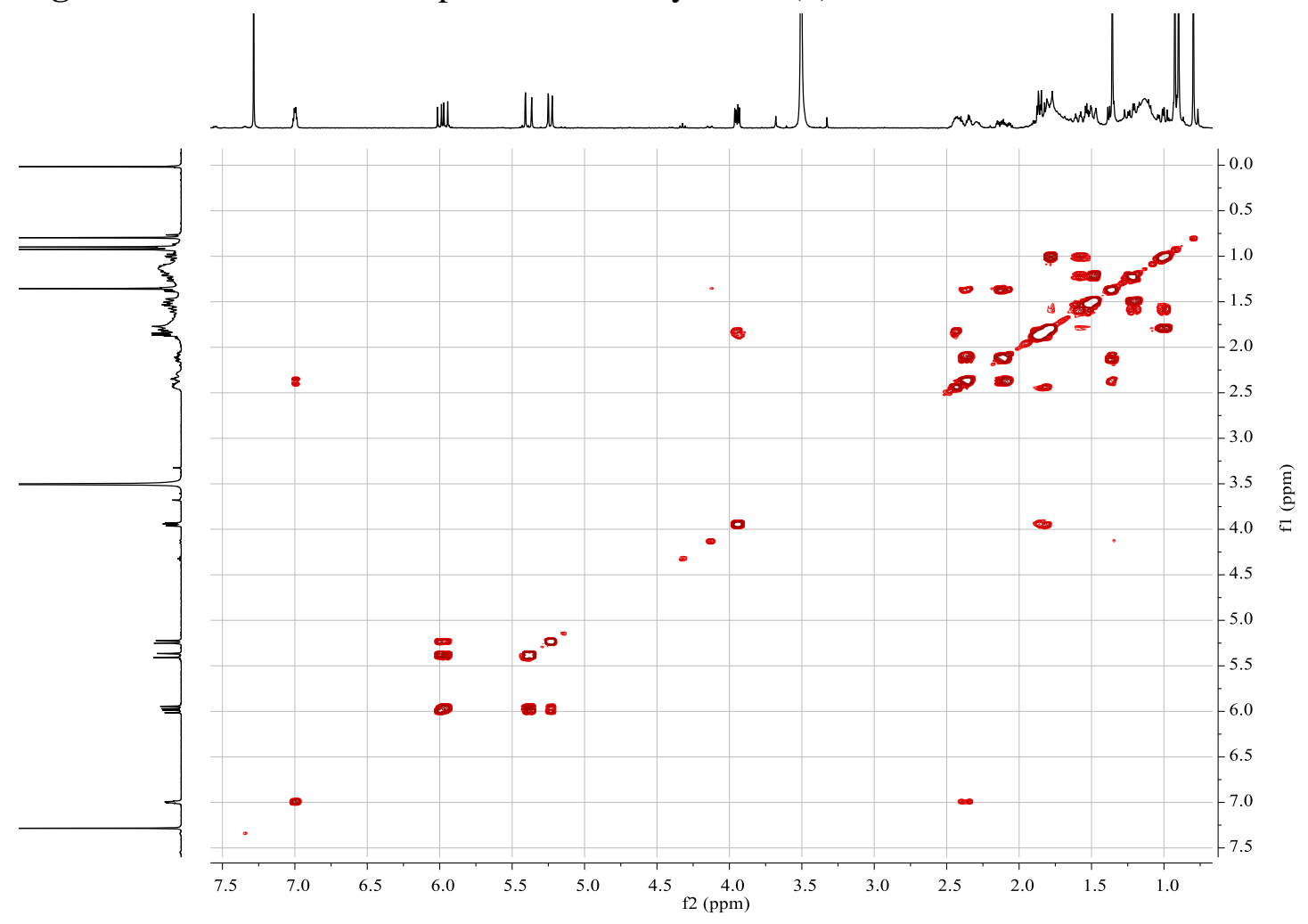

Figure S68. NOESY spectrum of sublyratin I (9) in $\mathrm{CDCl}_{3}$.

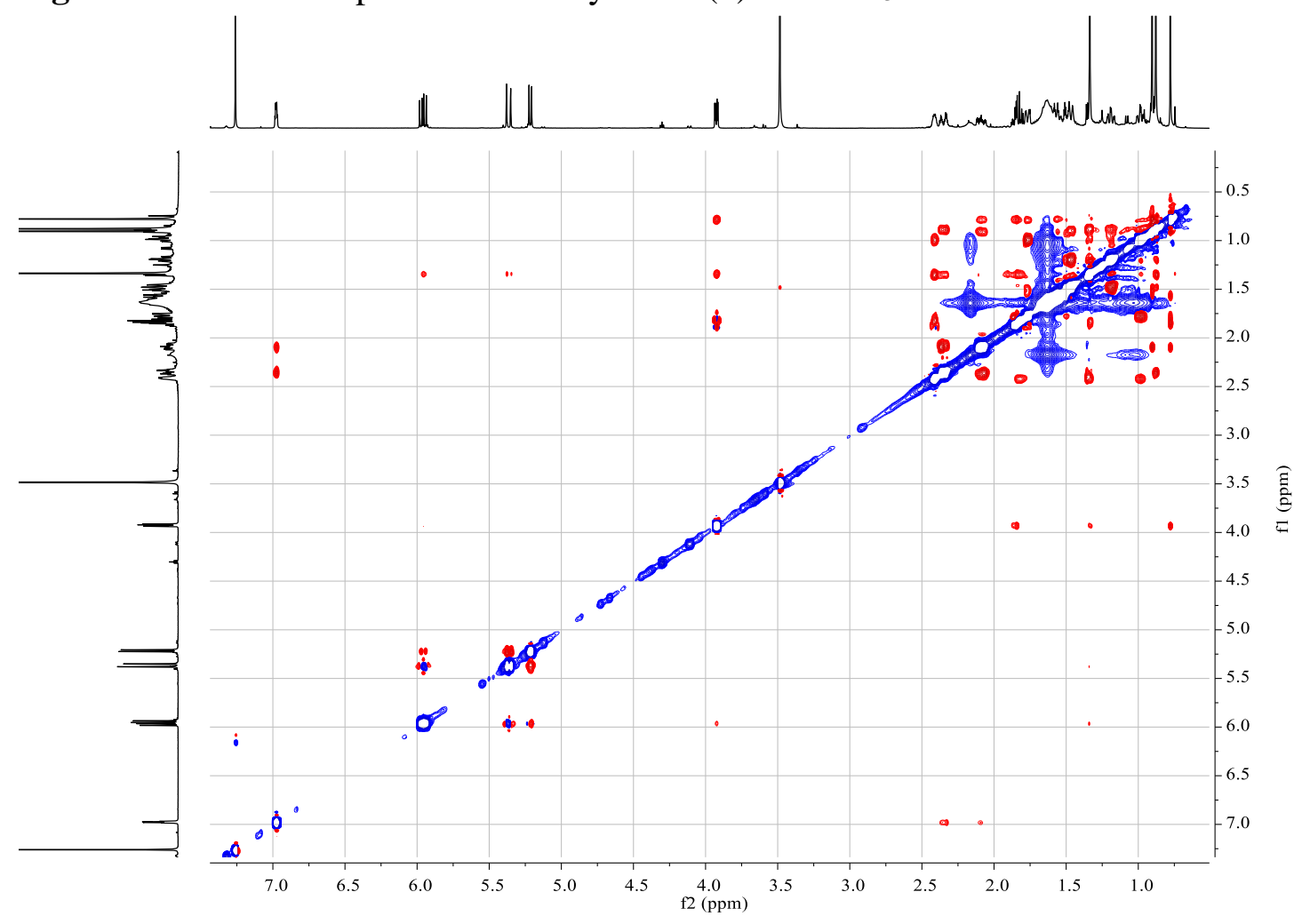


Figure S69. (+)-HRESIMS spectrum of sublyratin I (9).

\section{Qualitative Analysis Report}

$\begin{array}{llll}\text { Data Filename } & \text { ESIH_20200910_YJM_QJJ_23.d } & \text { Sample Name } & \text { D4-QBD-14a } \\ \text { Sample Type } & \text { Sample } & \text { Position } & \text { P1-C5 } \\ \text { Instrument Name } & \text { Agilent G6520 Q-TOF } & \text { Acq Method } & \text { 20160322_MS_ESIH_POS_1min.m } \\ \text { Acquired Time } & 9 / 11 / 202015: 47: 51 & \text { IRM Calibration Status } & \text { Success_ZY } \\ \text { DA Method } & \text { small molecular data analysis method.m } & \text { Comment } & \text { ESIH by ZZY }\end{array}$

DA Method

small molecular data analysis method.m

Comment

ESIH by ZZY

User Spectra

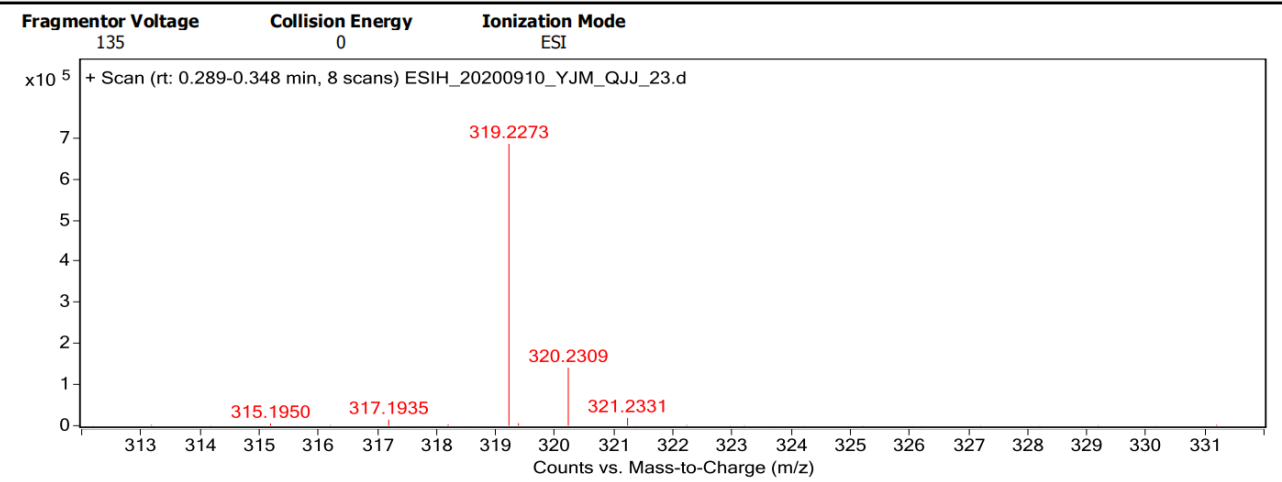

Formula Calculator Results

\begin{tabular}{|l|l|l|l|l|l|}
\hline $\mathbf{m} / \mathbf{z}$ & Calc $\mathbf{m} / \mathbf{z}$ & Diff $(\mathbf{m D a})$ & Diff $(\mathbf{p p m})$ & Ion Formula & Ion \\
\hline 319.2273 & 319.2268 & -0.51 & -1.6 & $\mathrm{C2} 2 \mathrm{H} 31 \mathrm{O} 3$ & $(\mathrm{M}+\mathrm{H})+$ \\
\hline
\end{tabular}

--- End Of Report --- 
Figure S70. ${ }^{1} \mathrm{H}$ NMR spectrum of sublyratin $\mathrm{J}(\mathbf{1 0})$ in $\mathrm{CDCl}_{3}$.

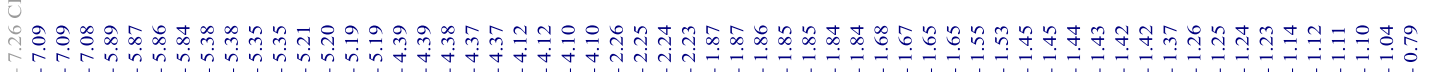

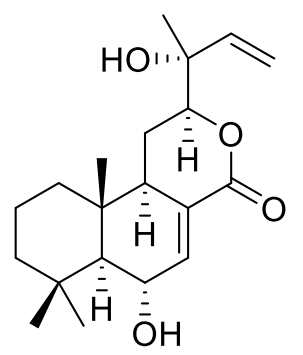

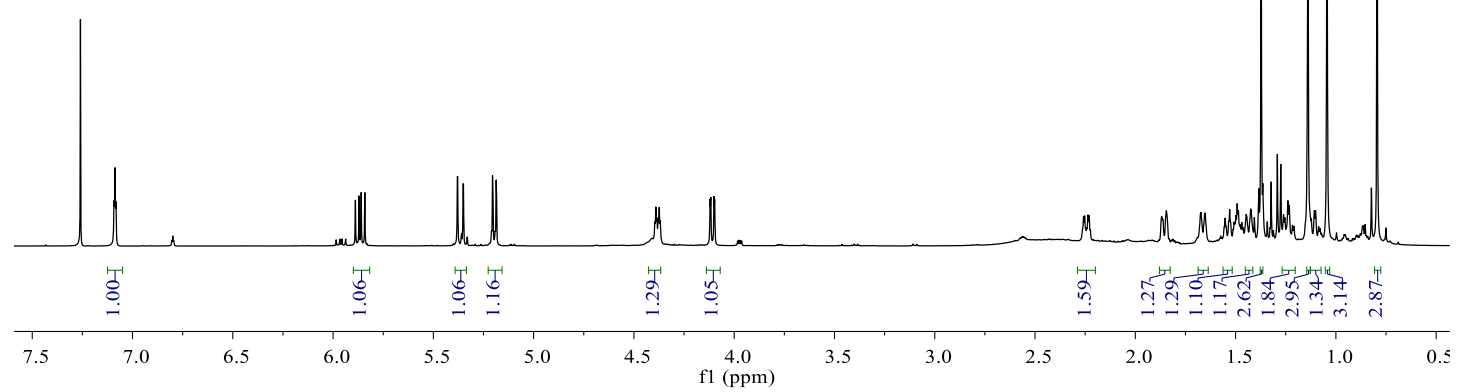

Figure S71. ${ }^{13} \mathrm{C}$ NMR spectrum of sublyratin $\mathrm{J}(\mathbf{1 0})$ in $\mathrm{CDCl}_{3}$.

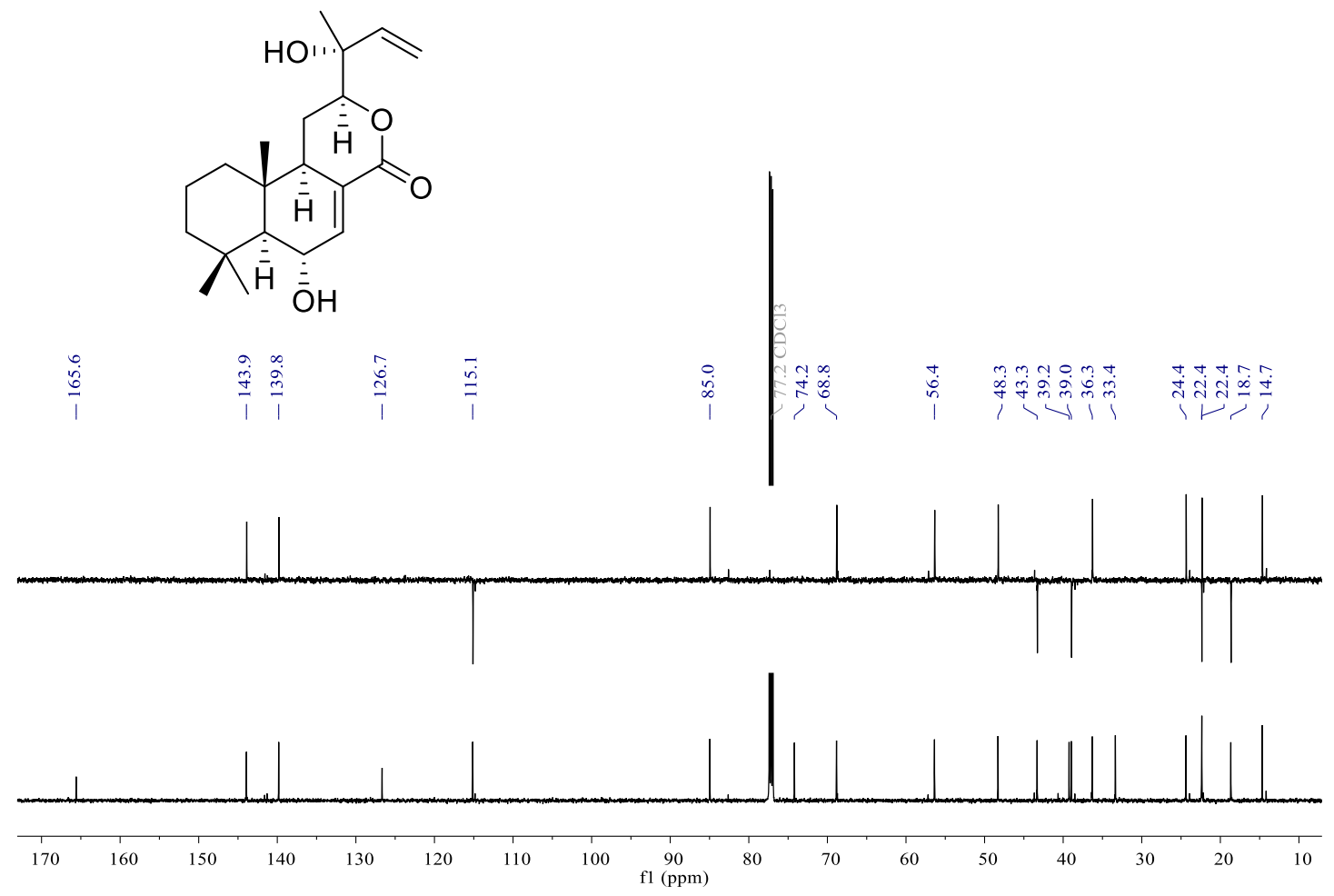


Figure S72. HSQC spectrum of sublyratin J (10) in $\mathrm{CDCl}_{3}$.

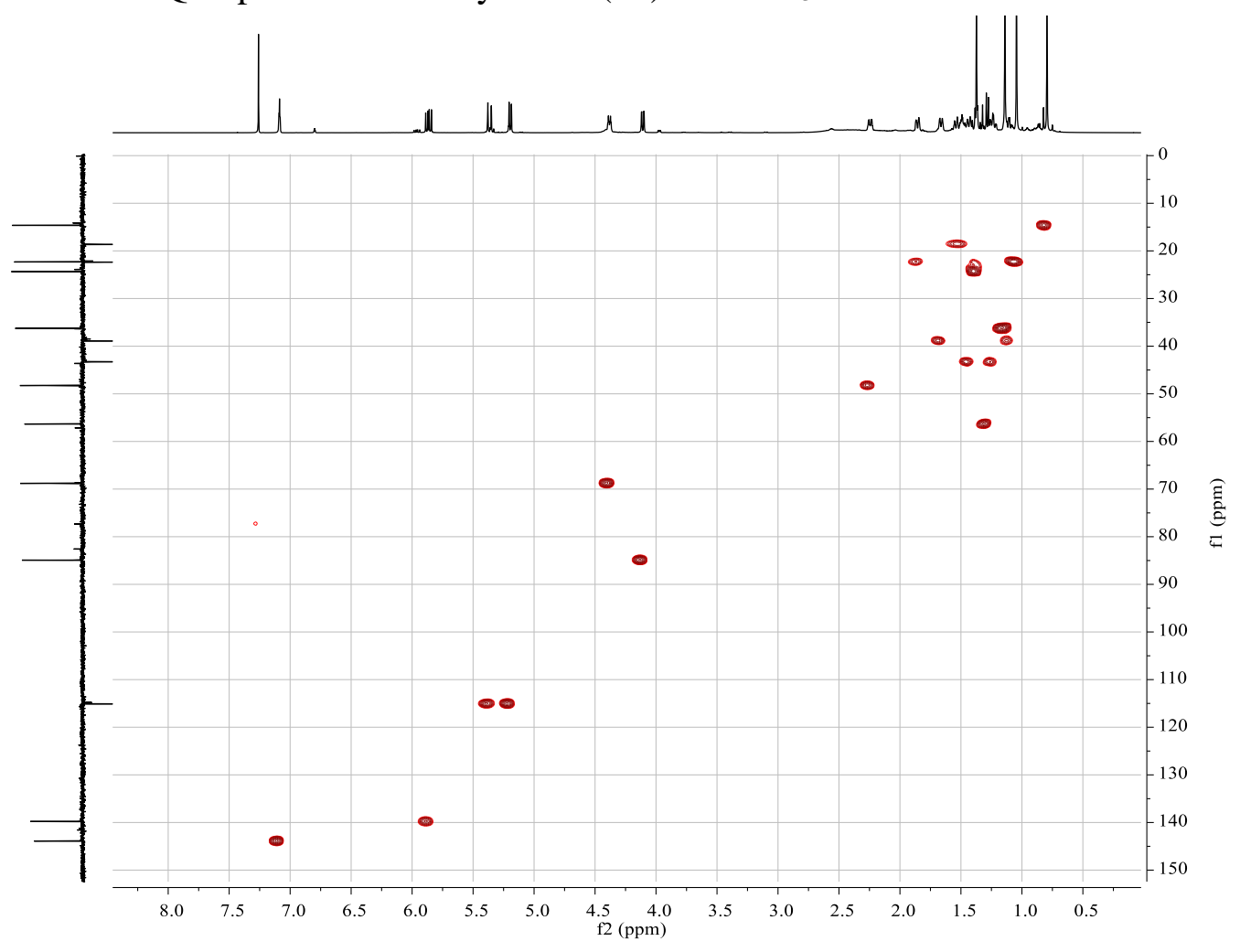

Figure S73. HMBC spectrum of sublyratin $\mathrm{J}(\mathbf{1 0})$ in $\mathrm{CDCl}_{3}$.

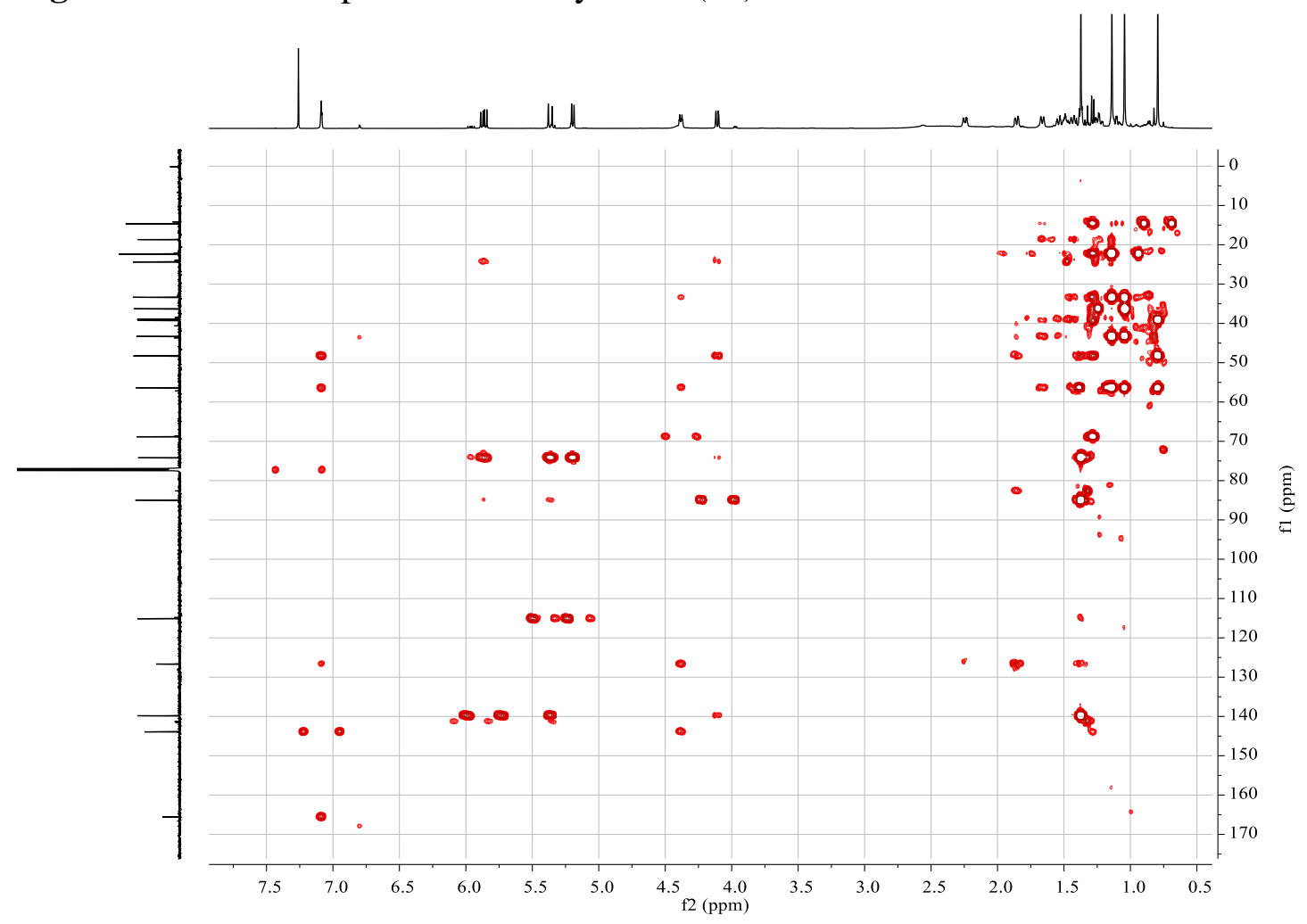


Figure S74. ${ }^{1} \mathrm{H}-{ }^{1} \mathrm{H}$ COSY spectrum of sublyratin $\mathrm{J}(\mathbf{1 0})$ in $\mathrm{CDCl}_{3}$.

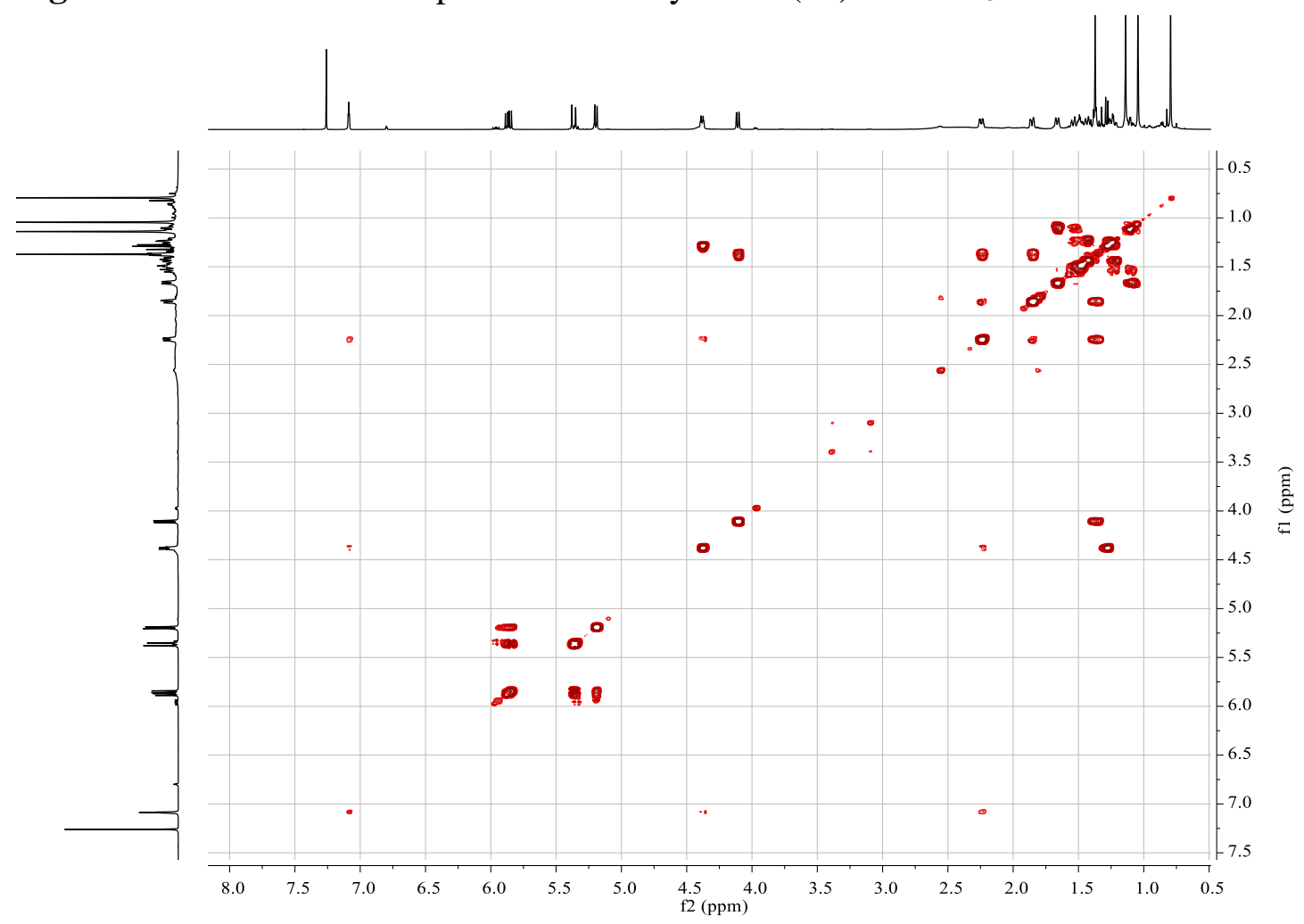

Figure S75. NOESY spectrum of sublyratin $\mathrm{J}(\mathbf{1 0})$ in $\mathrm{CDCl}_{3}$.

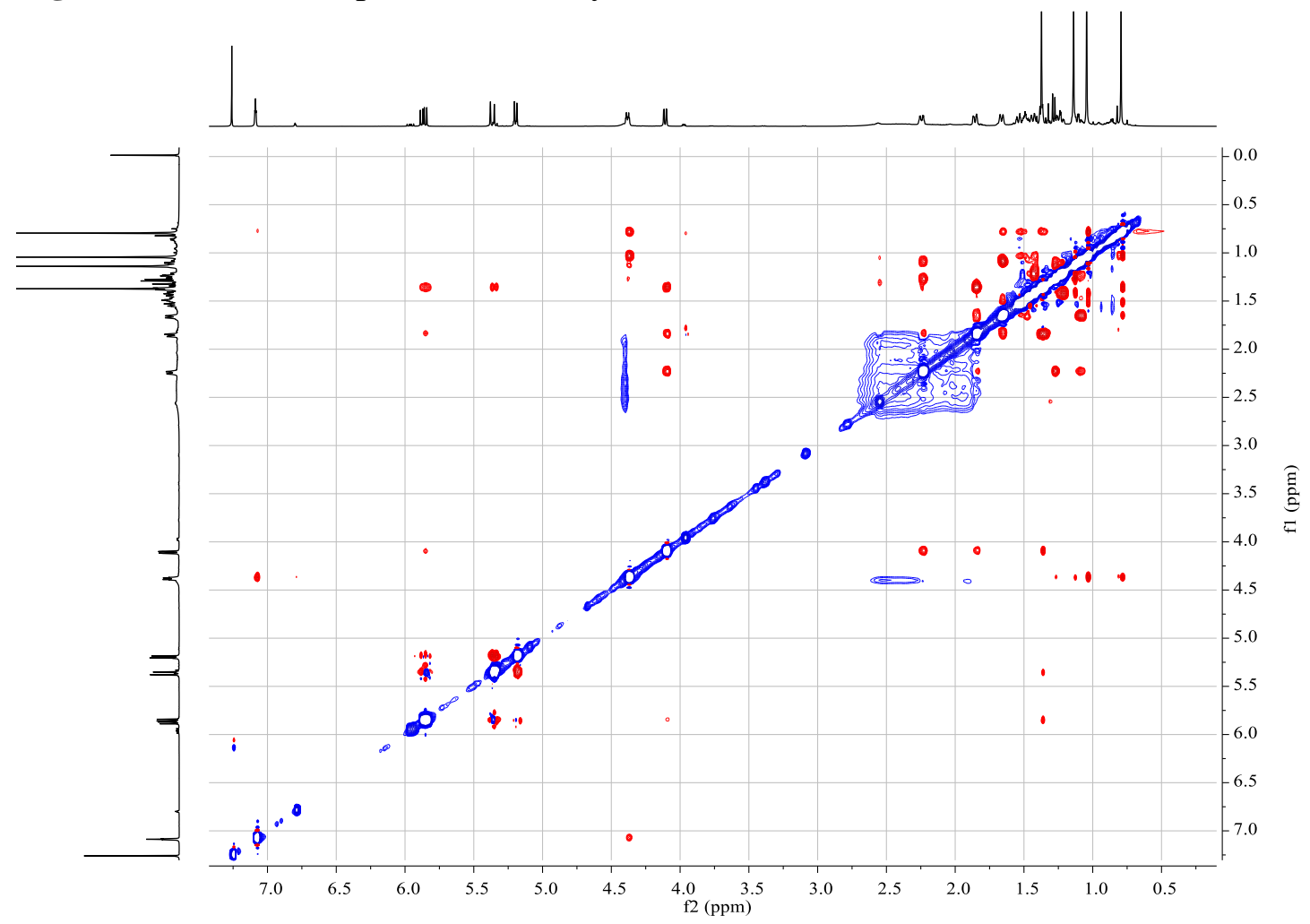


Figure S76. (+)-HRESIMS spectrum of sublyratin J (10).

Qualitative Analysis Report

$\begin{array}{llll}\text { Data Filename } & \text { ESIH_20200827_YJM_QJJ_15.d } & \text { Sample Name } & \text { D4-QBD-11a } \\ \text { Sample Type } & \text { Sample } & \text { Position } & \text { P1-B6 } \\ \text { Instrument Name } & \text { Agilent G6520 Q-TOF } & \text { Acq Method } & \text { 20160322_MS_ESIH_POS_1min.m } \\ \text { Acquired Time } & 8 / 27 / 202013: 14: 10 & \text { IRM Calibration Status } & \text { Success } \\ \text { DA Method } & \text { small molecular data analysis method.m } & \text { Comment } & \text { ESIH by ZZY }\end{array}$

User Spectra

small molecular data analysis method.m

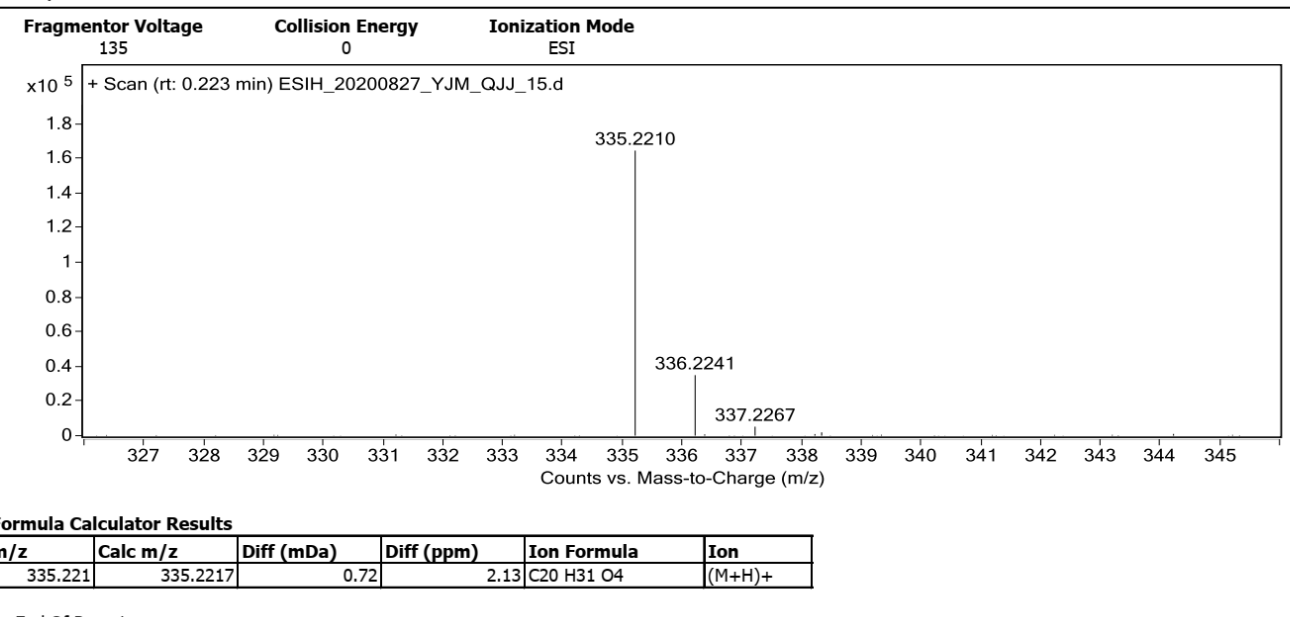

--- End Of Report -.- 
Figure S77. ${ }^{1} \mathrm{H}$ NMR spectrum of sublyratin $\mathrm{K}(\mathbf{1 1})$ in $\mathrm{CDCl}_{3}$.

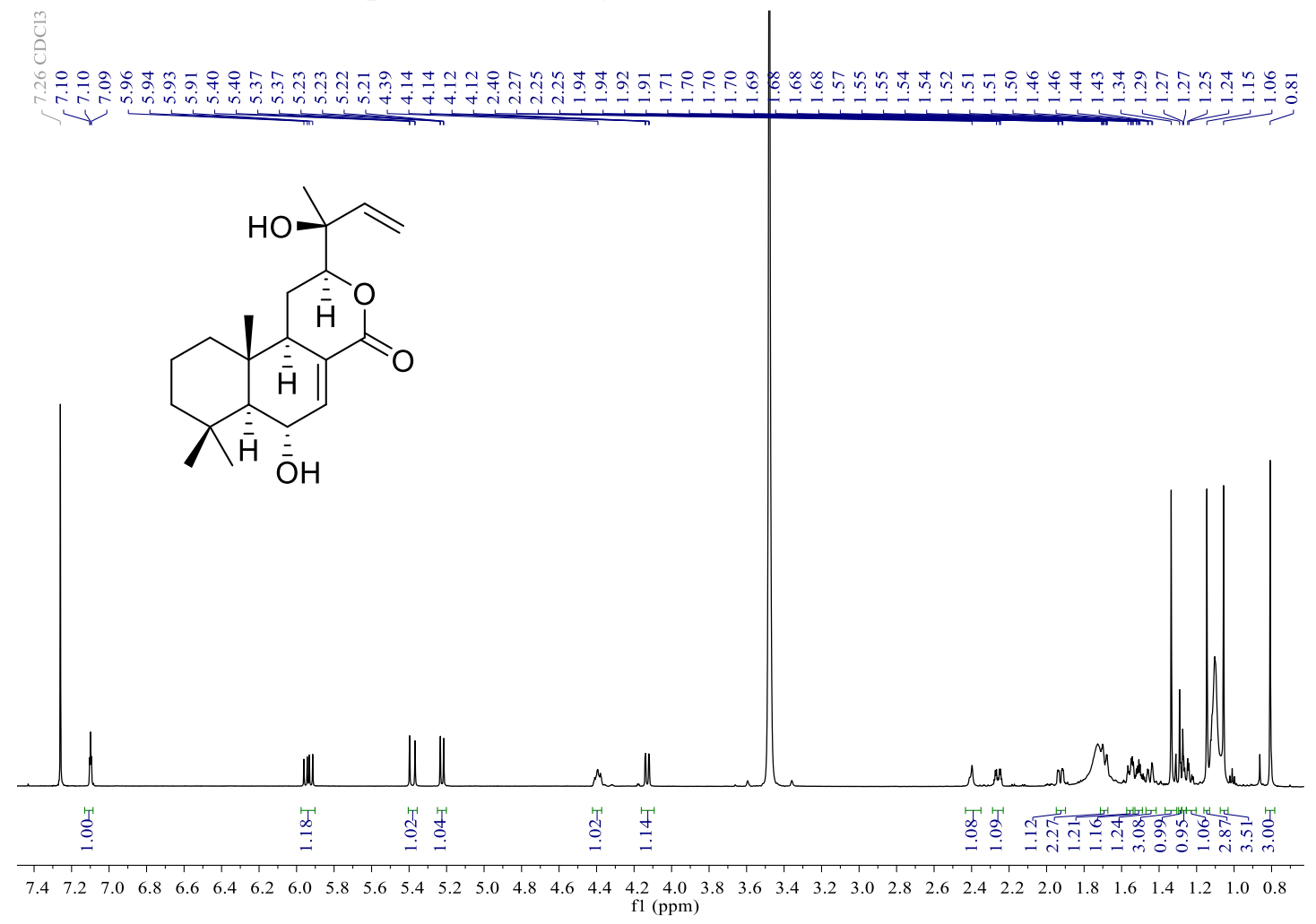

Figure S78. ${ }^{13} \mathrm{C}$ NMR spectrum of sublyratin $\mathrm{K}(11)$ in $\mathrm{CDCl}_{3}$.

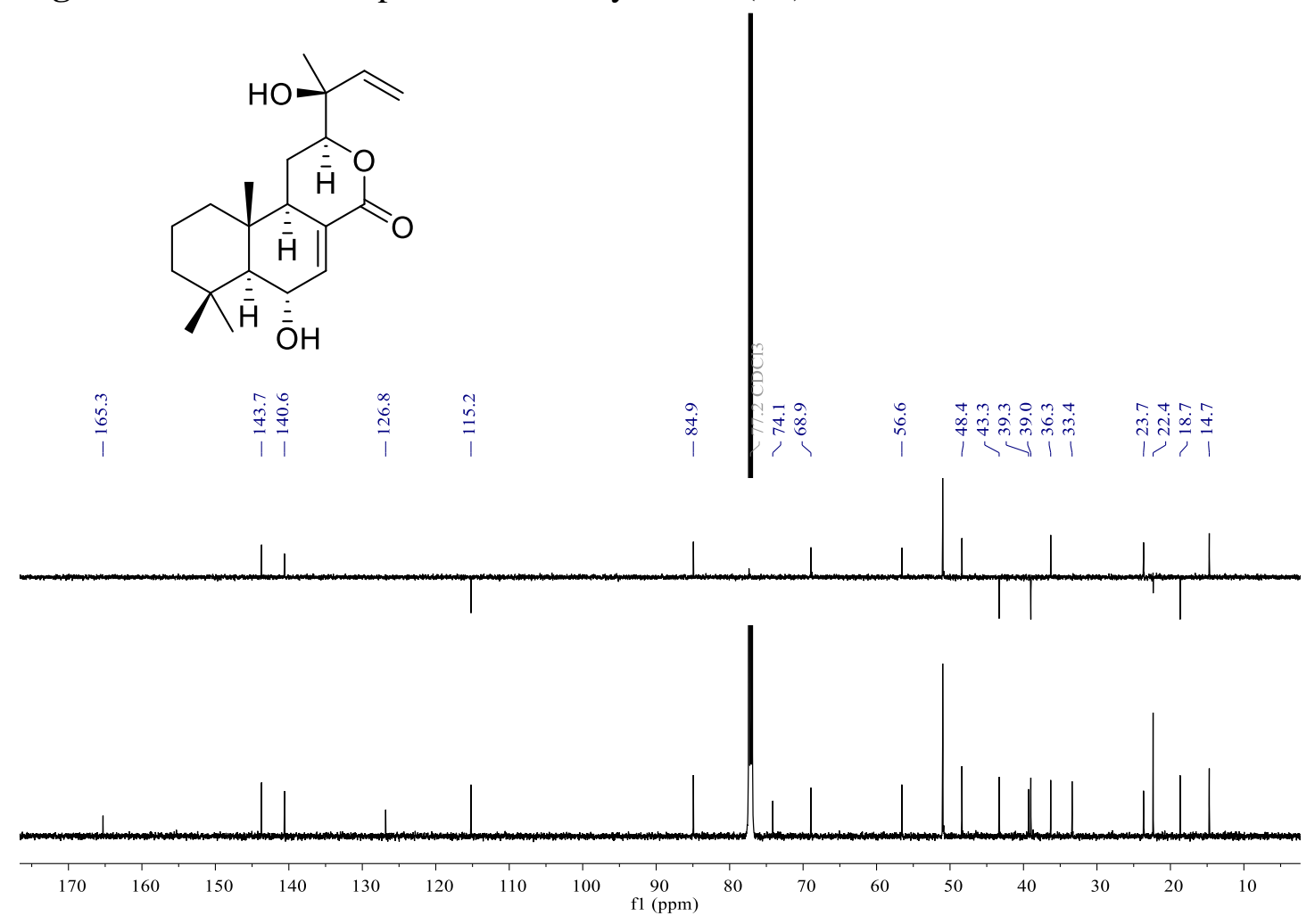


Figure S79. HSQC spectrum of sublyratin $\mathrm{K}(\mathbf{1 1})$ in $\mathrm{CDCl}_{3}$.

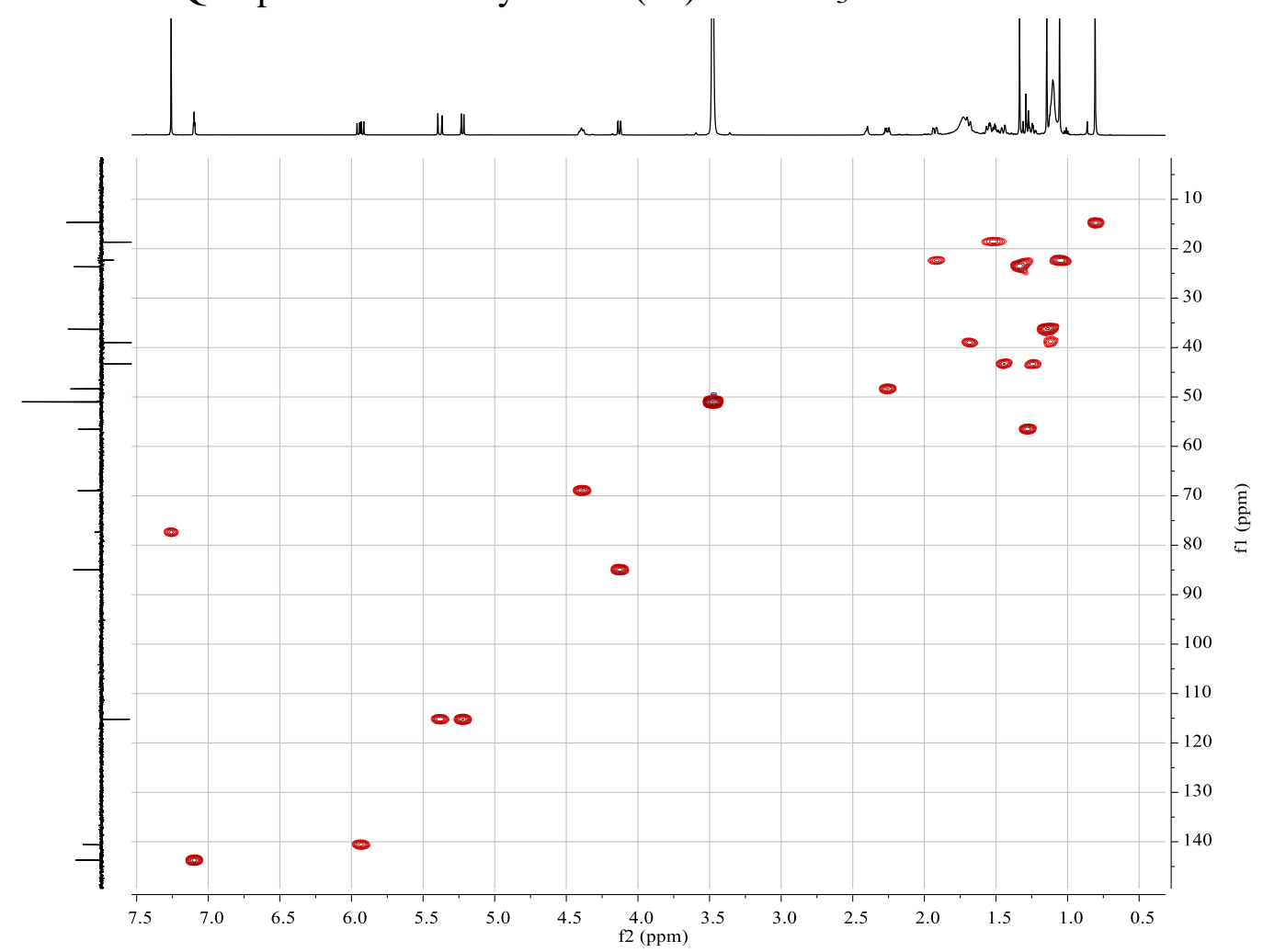

Figure S80. HMBC spectrum of sublyratin $\mathrm{K}(\mathbf{1 1})$ in $\mathrm{CDCl}_{3}$.

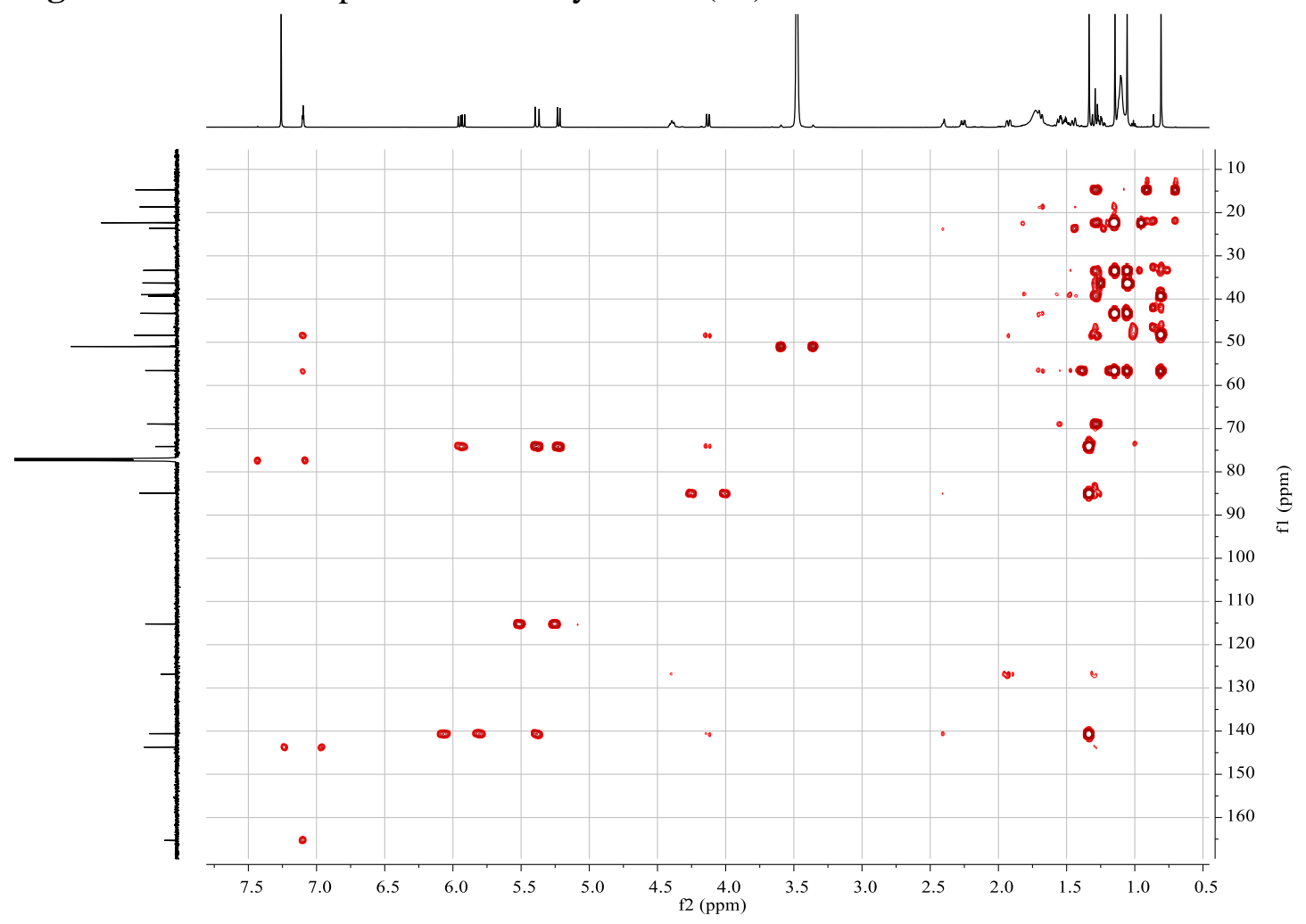


Figure S81. ${ }^{1} \mathrm{H}-{ }^{1} \mathrm{H}$ COSY spectrum of sublyratin $\mathrm{K}(\mathbf{1 1})$ in $\mathrm{CDCl}_{3}$.

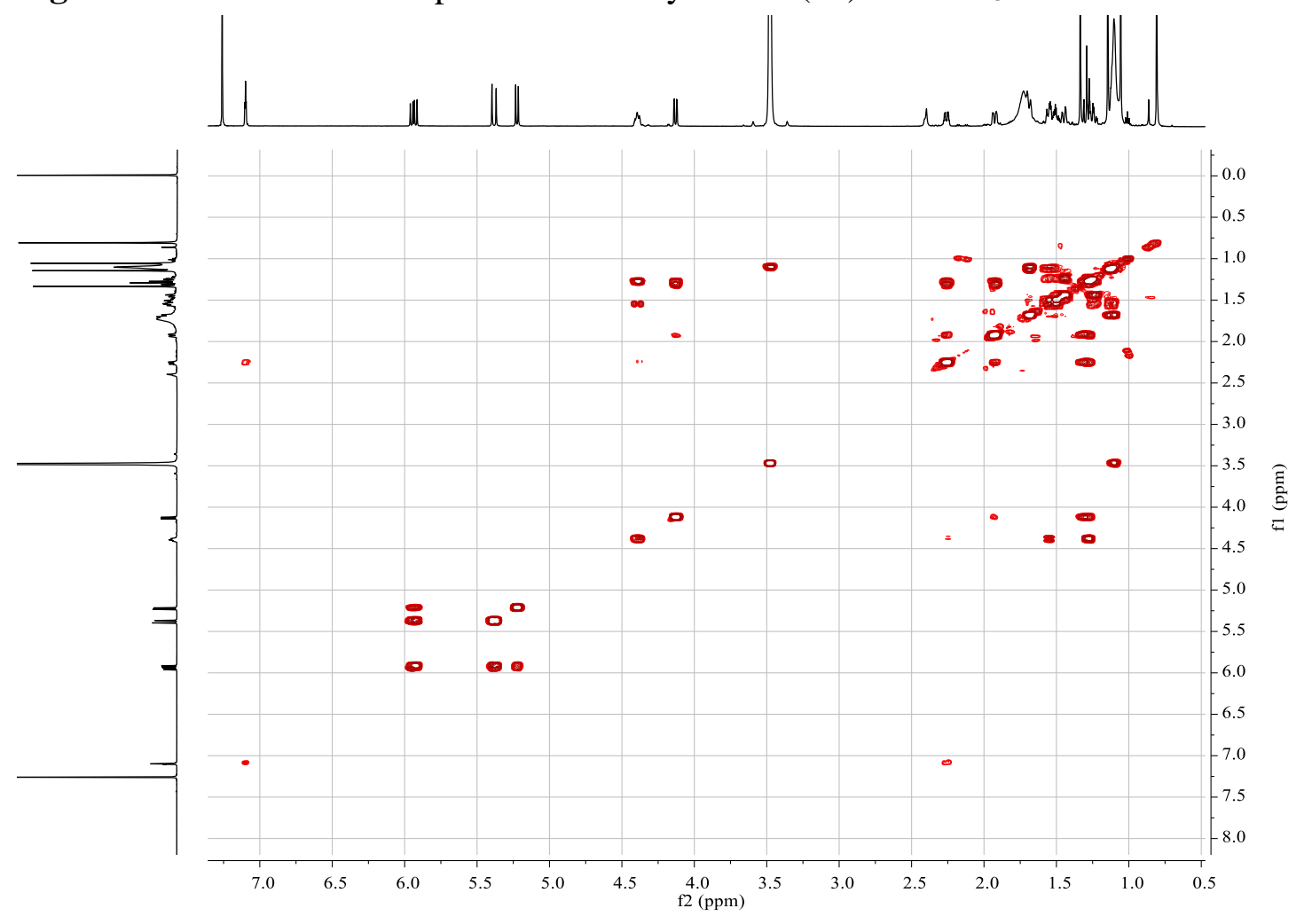

Figure S82. NOESY spectrum of sublyratin $\mathrm{K}(\mathbf{1 1})$ in $\mathrm{CDCl}_{3}$.

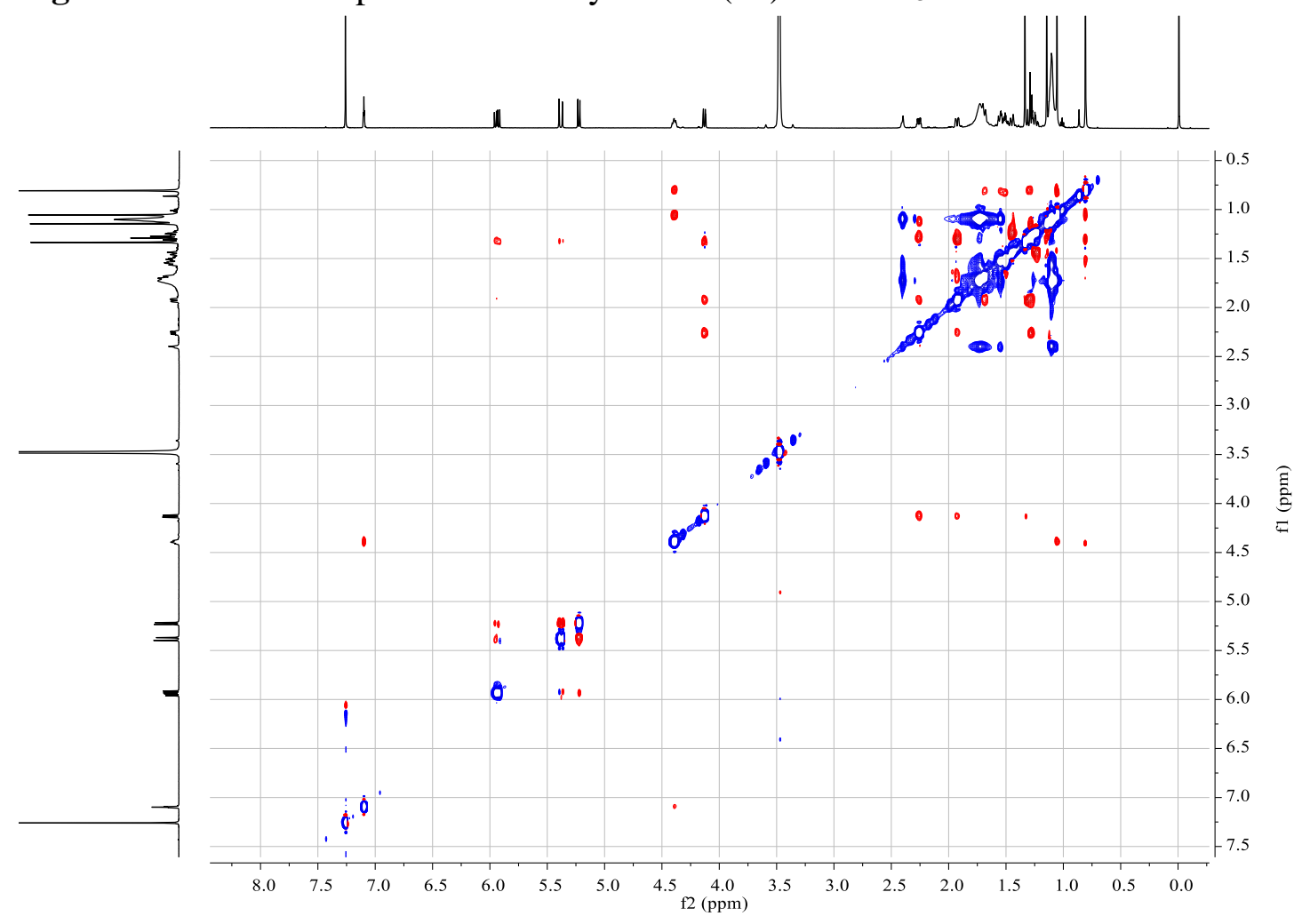


Figure S83. (+)-HRESIMS spectrum of sublyratin K (11).

Qualitative Analysis Report

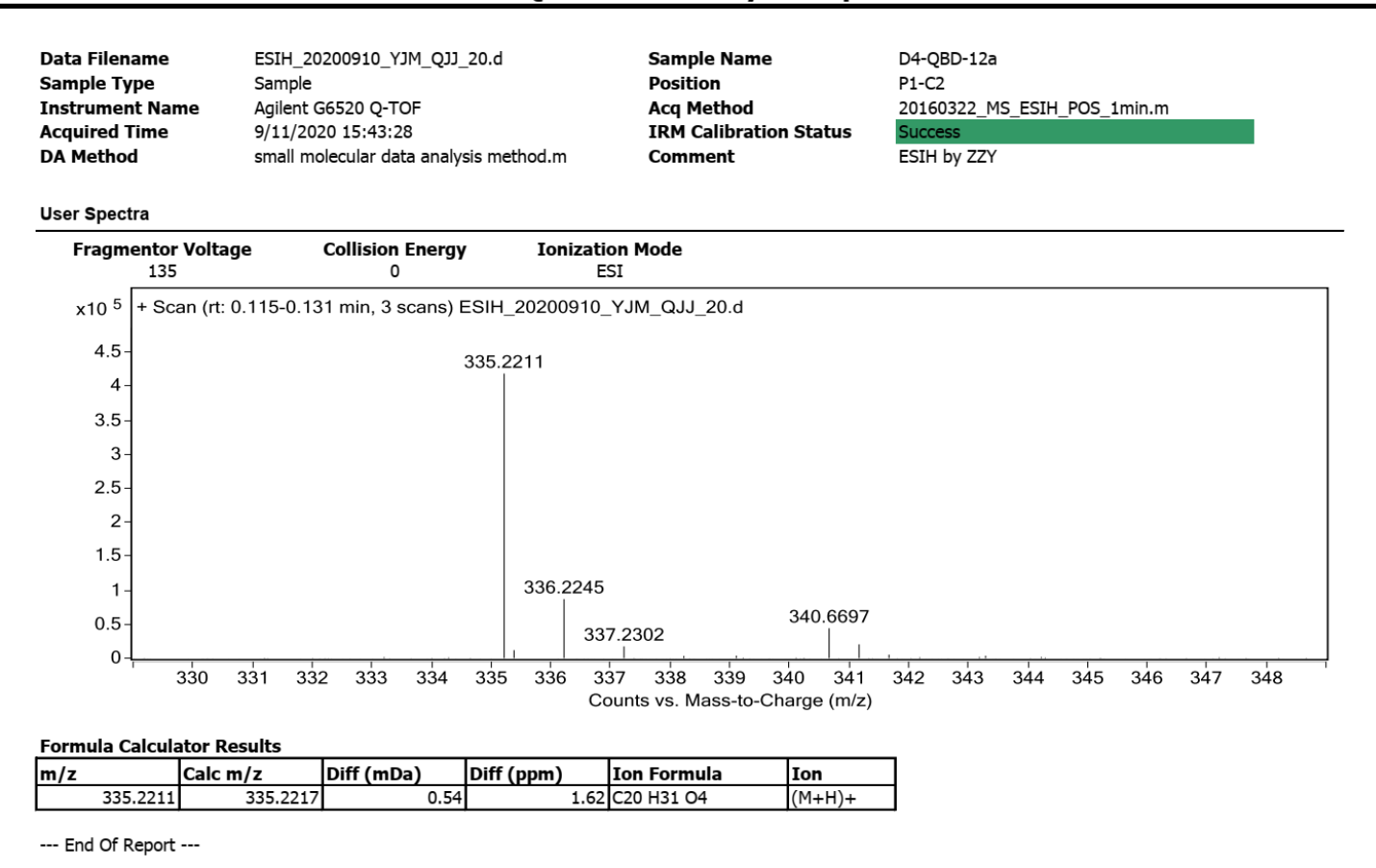


Figure S84. ${ }^{1} \mathrm{H}$ NMR spectrum of sublyratin $\mathrm{L}(\mathbf{1 2})$ in $\mathrm{CDCl}_{3}$.

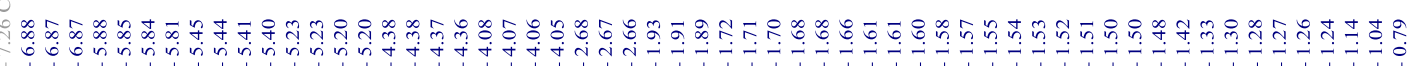<smiles>C=CC(C)(O)C1CC2C(=C[C@H](O)[C@]3(C)C(C)CCC[C@]23C)C(=O)O1</smiles>

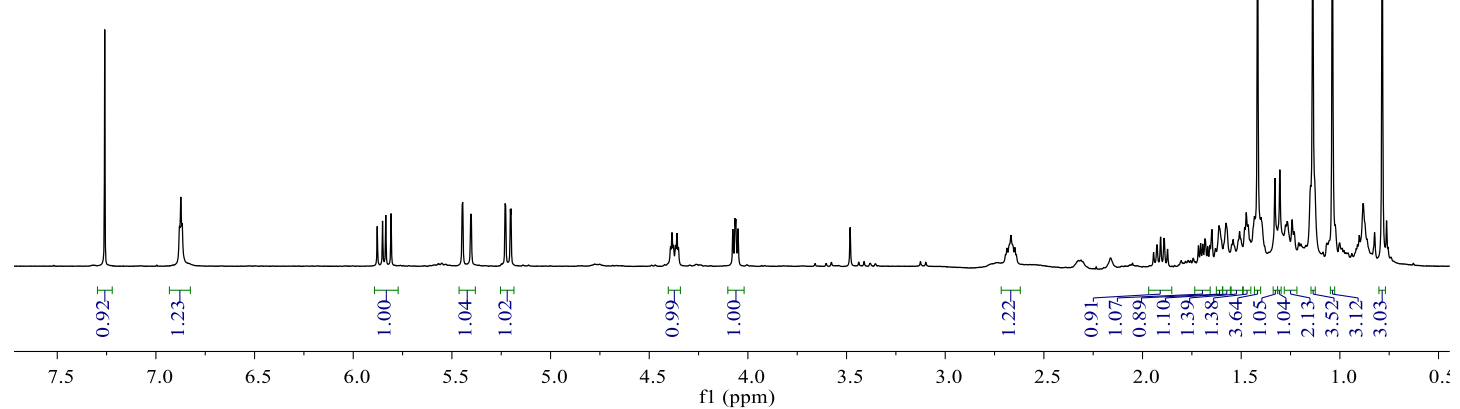

Figure S85. ${ }^{13} \mathrm{C}$ NMR spectrum of sublyratin $\mathrm{L}(\mathbf{1 2})$ in $\mathrm{CDCl}_{3}$.
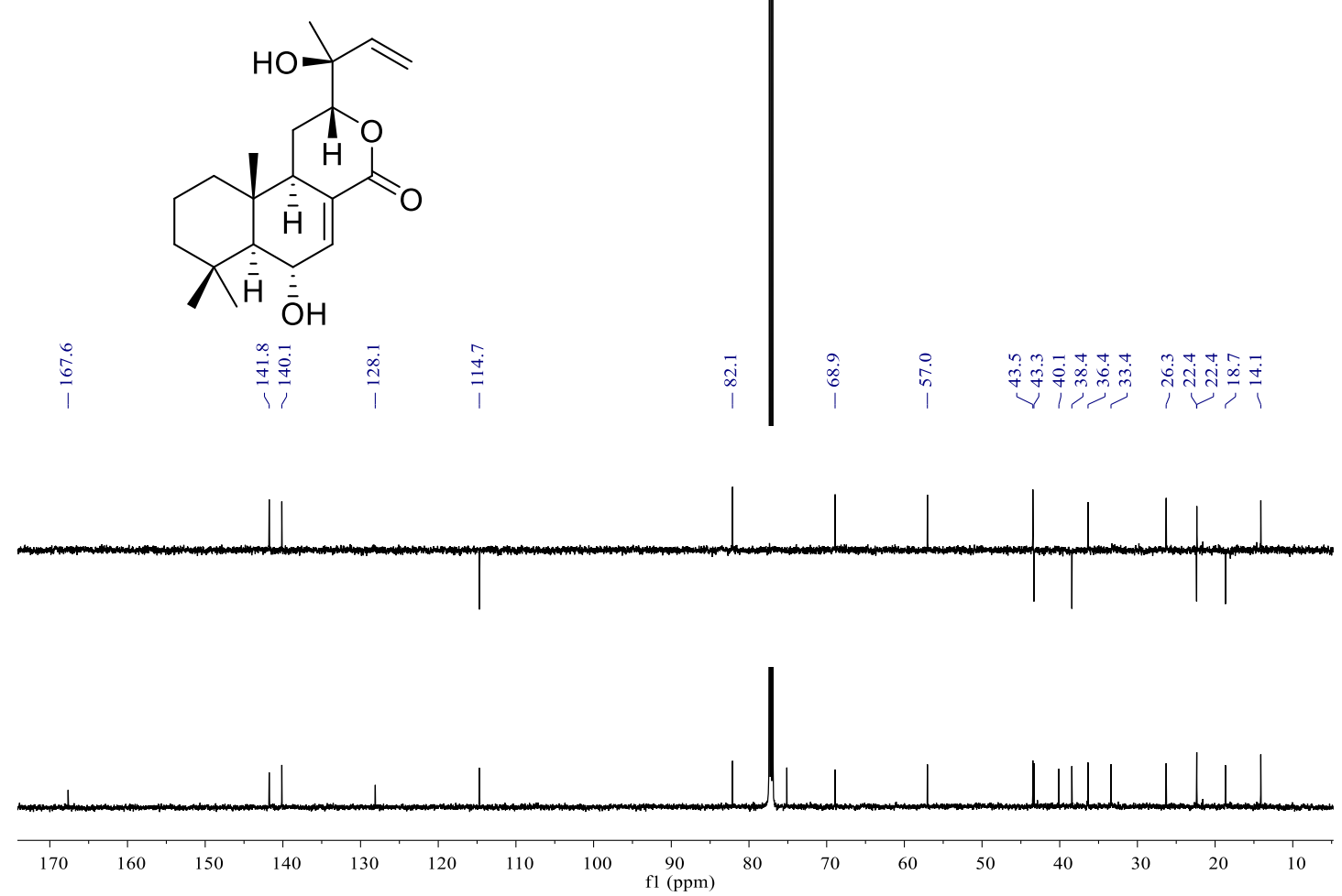
Figure S86. HSQC spectrum of sublyratin $\mathrm{L}(\mathbf{1 2})$ in $\mathrm{CDCl}_{3}$.

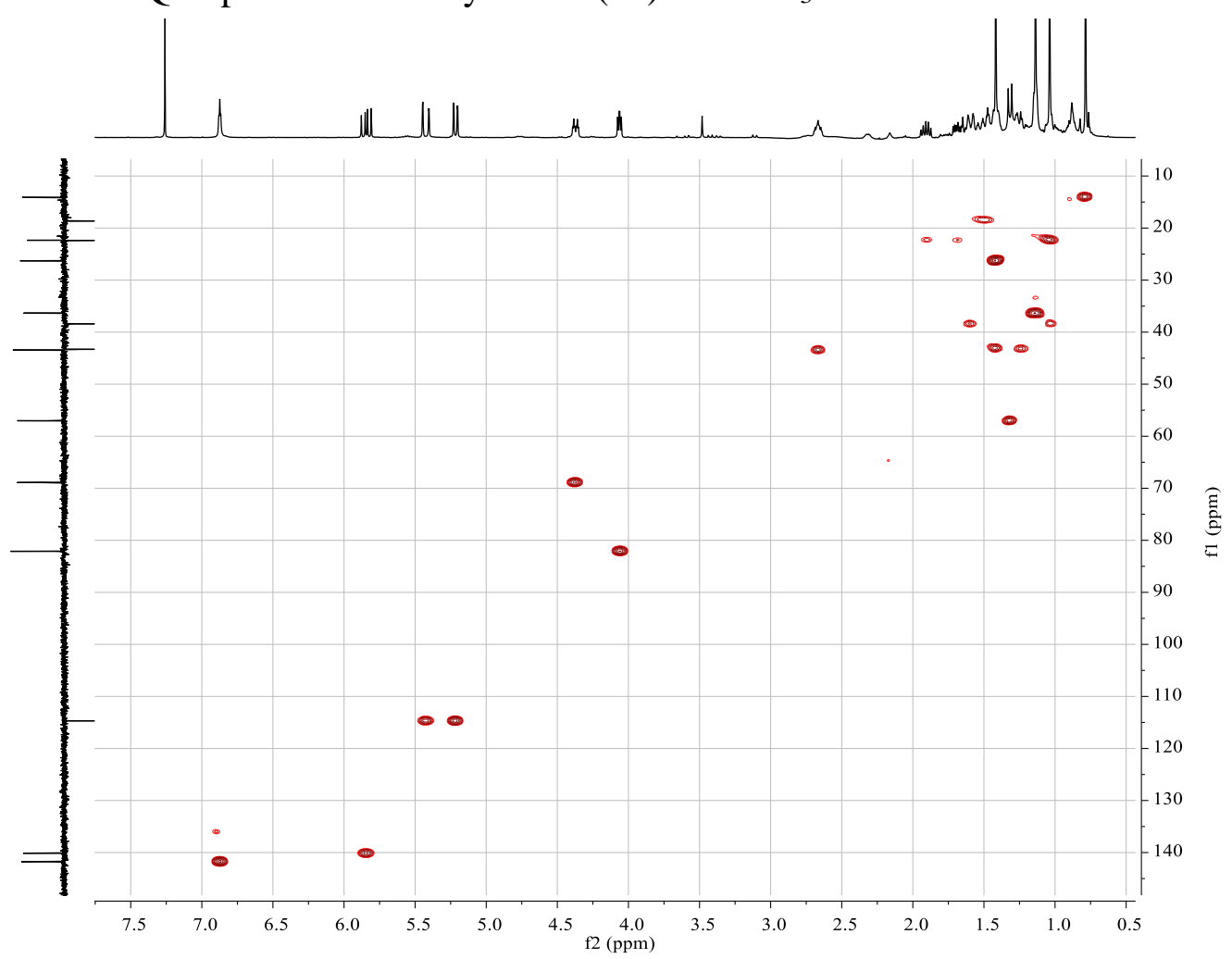

Figure S87. HMBC spectrum of sublyratin $\mathrm{L}(12)$ in $\mathrm{CDCl}_{3}$.

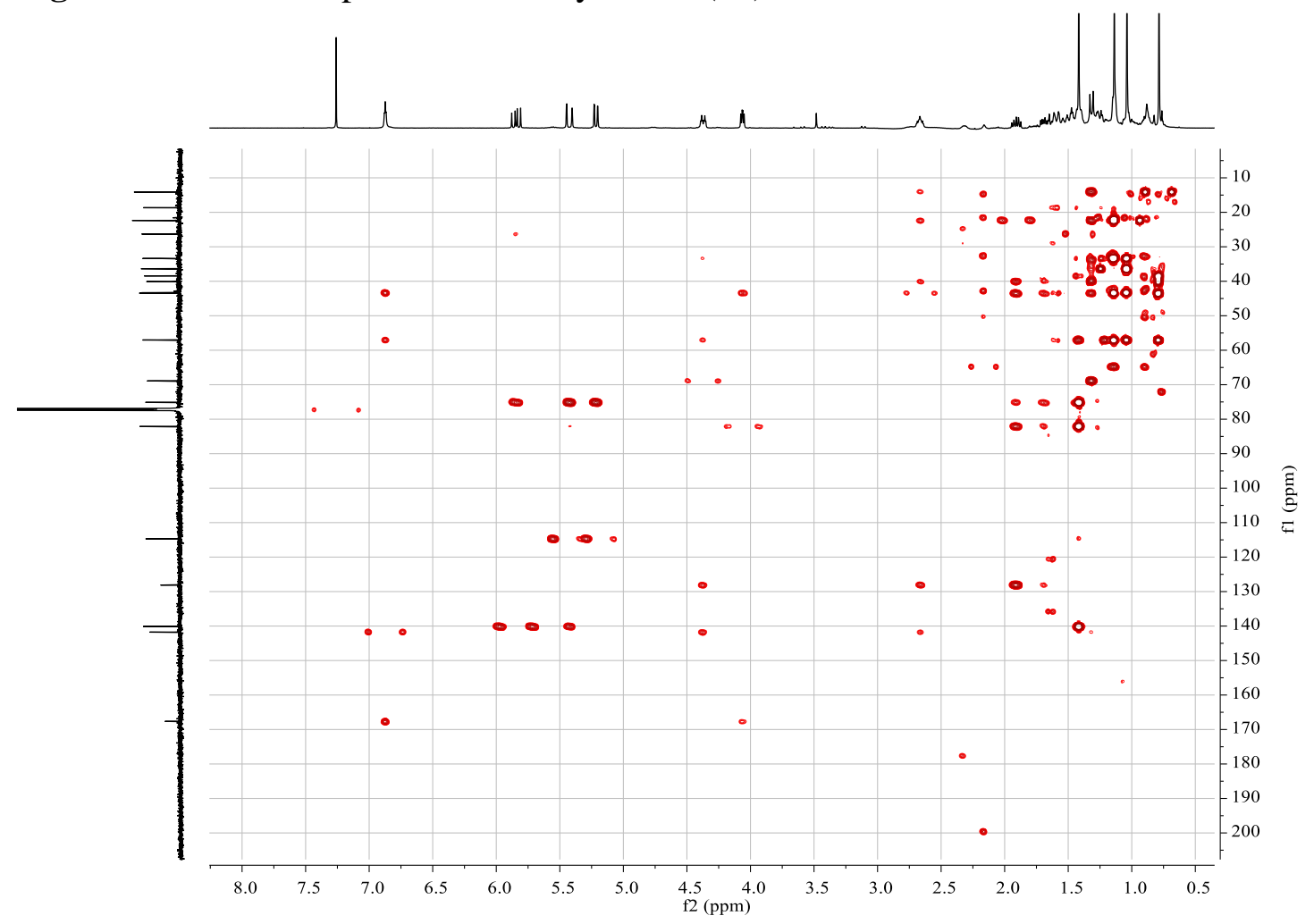


Figure S88. ${ }^{1} \mathrm{H}-{ }^{1} \mathrm{H}$ COSY spectrum of sublyratin $\mathrm{L}(\mathbf{1 2})$ in $\mathrm{CDCl}_{3}$.

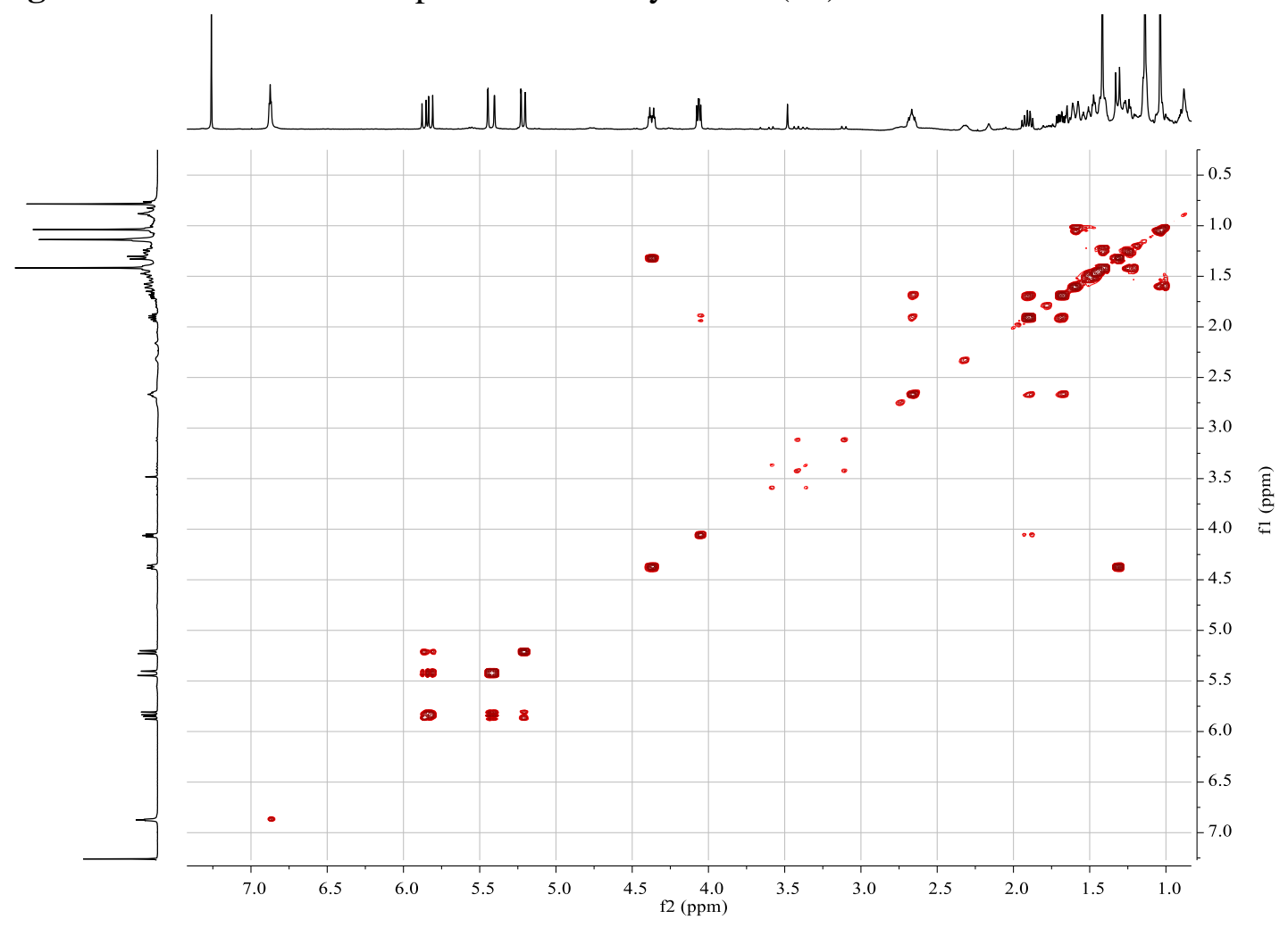

Figure S89. NOESY spectrum of sublyratin $\mathrm{L}(\mathbf{1 2})$ in $\mathrm{CDCl}_{3}$.

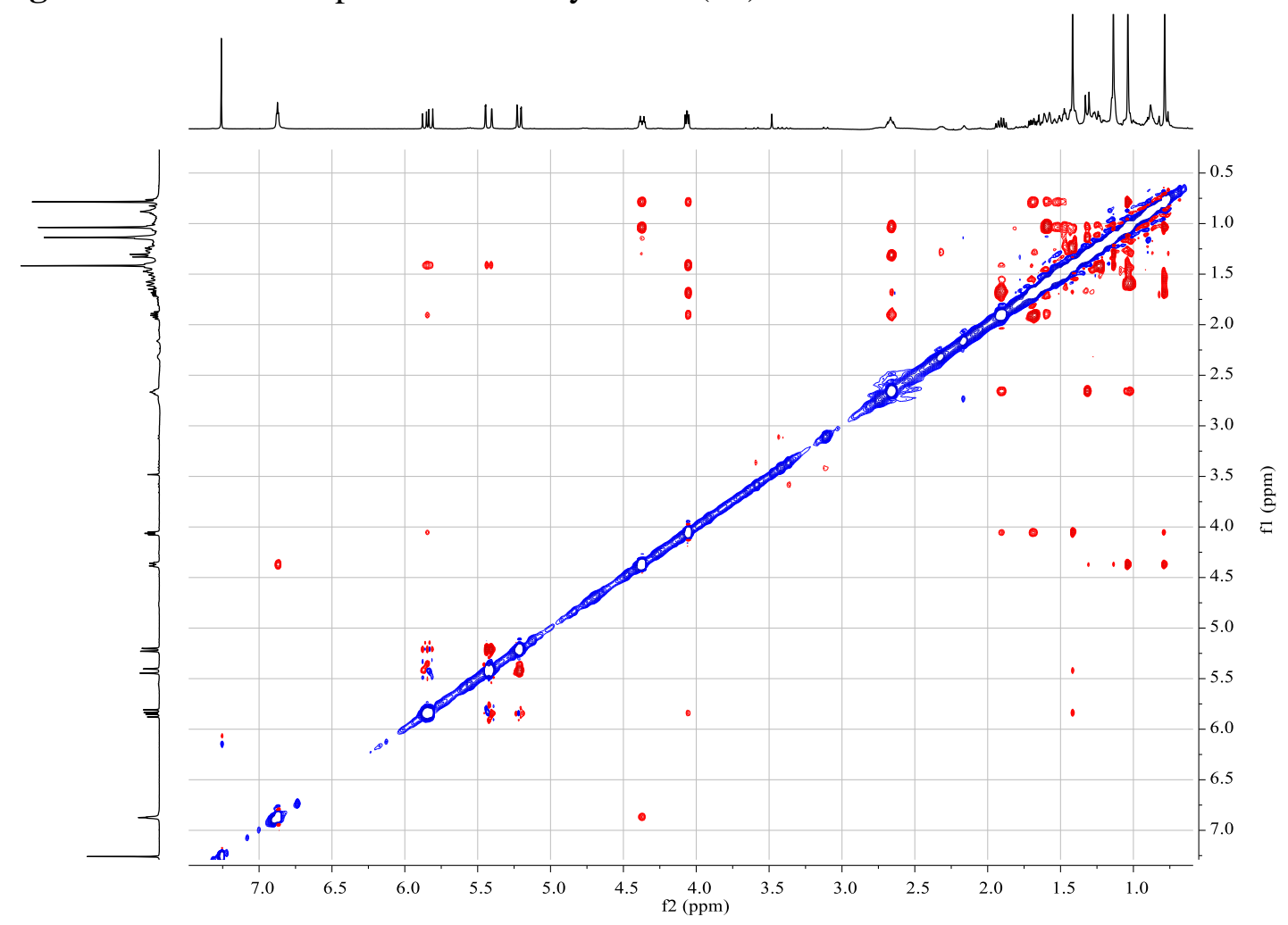


Figure S90. (+)-HRESIMS spectrum of sublyratin L (12).

Qualitative Analysis Report

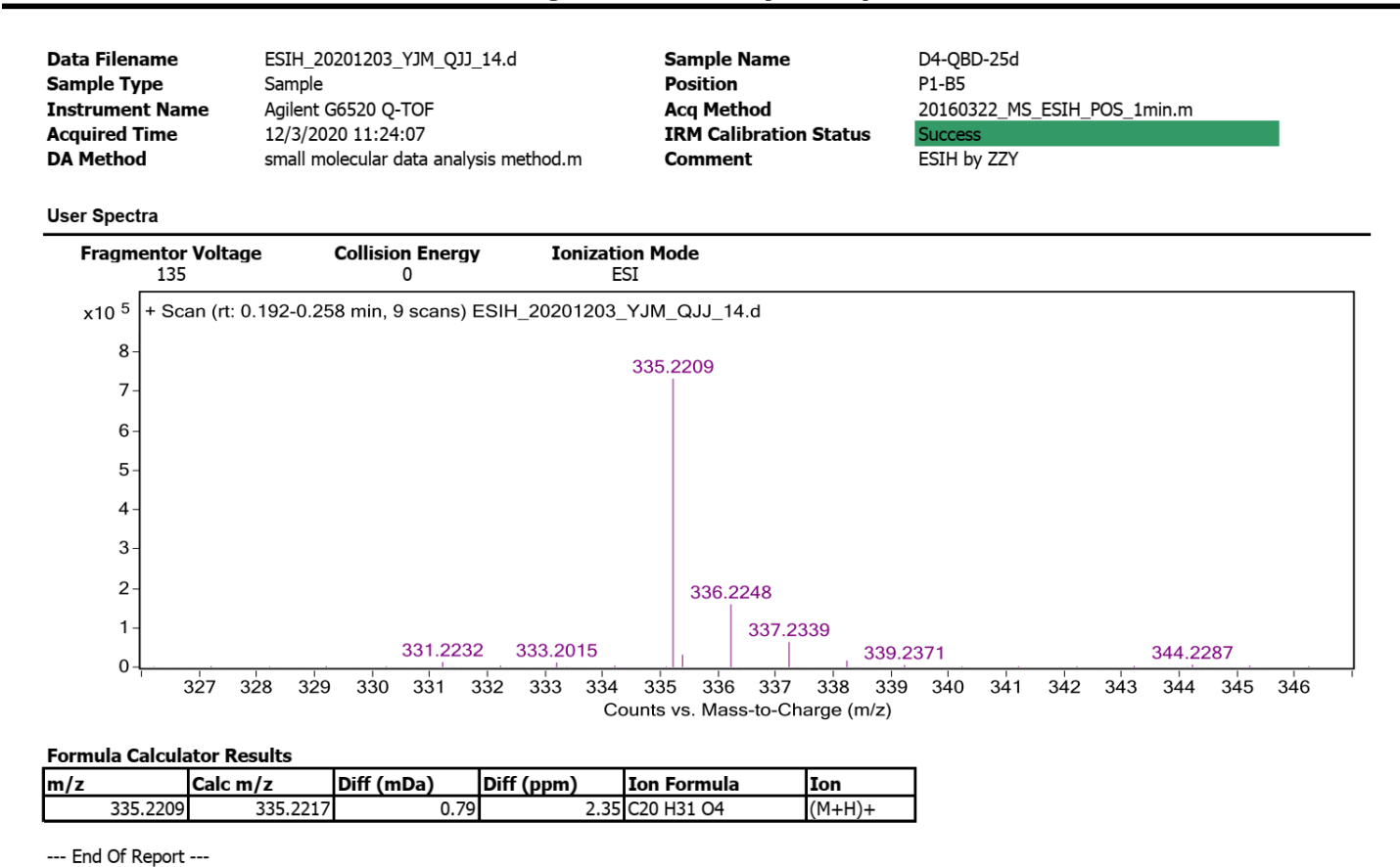


Figure S91. ${ }^{1} \mathrm{H}$ NMR spectrum of sublyratin $\mathrm{M}(\mathbf{1 3})$ in $\mathrm{CDCl}_{3}$.

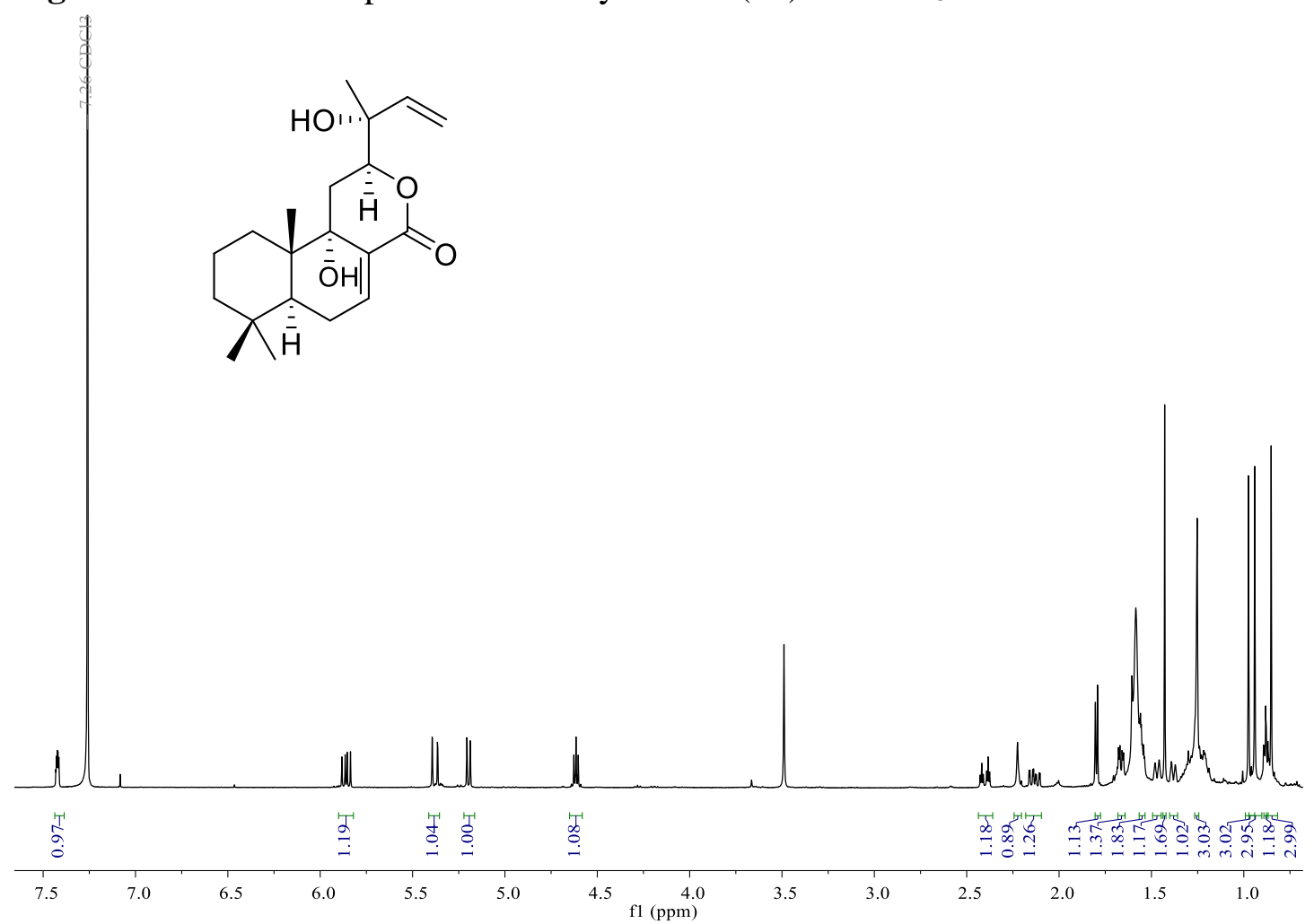

Figure S92. ${ }^{13} \mathrm{C}$ NMR spectrum of sublyratin $\mathrm{M}(\mathbf{1 3})$ in $\mathrm{CDCl}_{3}$.

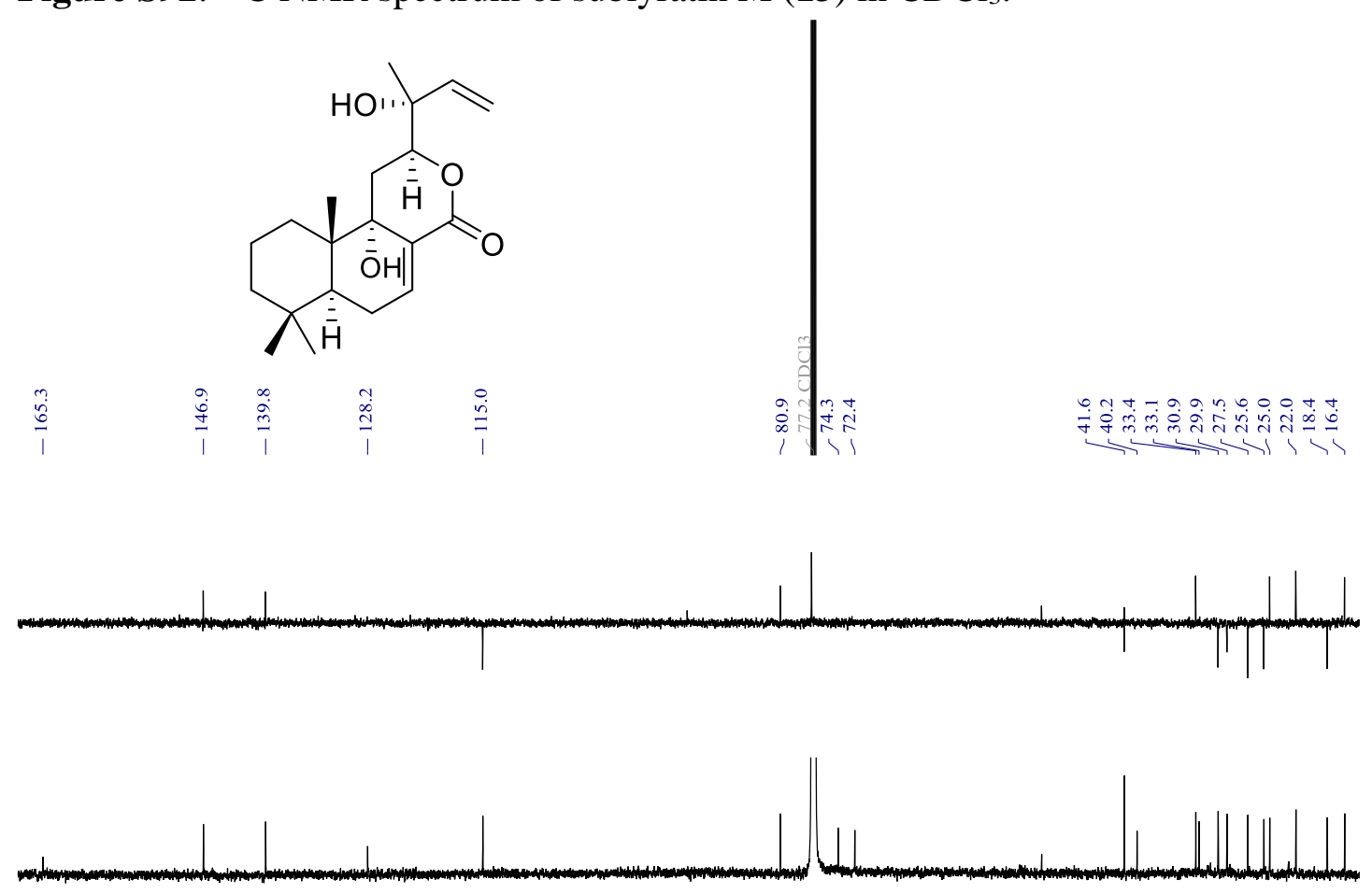

$\begin{array}{lllllllllllllllllllllllllllllllll}165 & 160 & 155 & 150 & 145 & 140 & 135 & 130 & 125 & 120 & 115 & 110 & 105 & 100 & 95 & 90 & 85 & 80 & 75 & 70 & 65 & 60 & 55 & 50 & 45 & 40 & 35 & 30 & 25 & 20 & 1\end{array}$ 
Figure S93. HSQC spectrum of sublyratin $\mathrm{M}(\mathbf{1 3})$ in $\mathrm{CDCl}_{3}$.

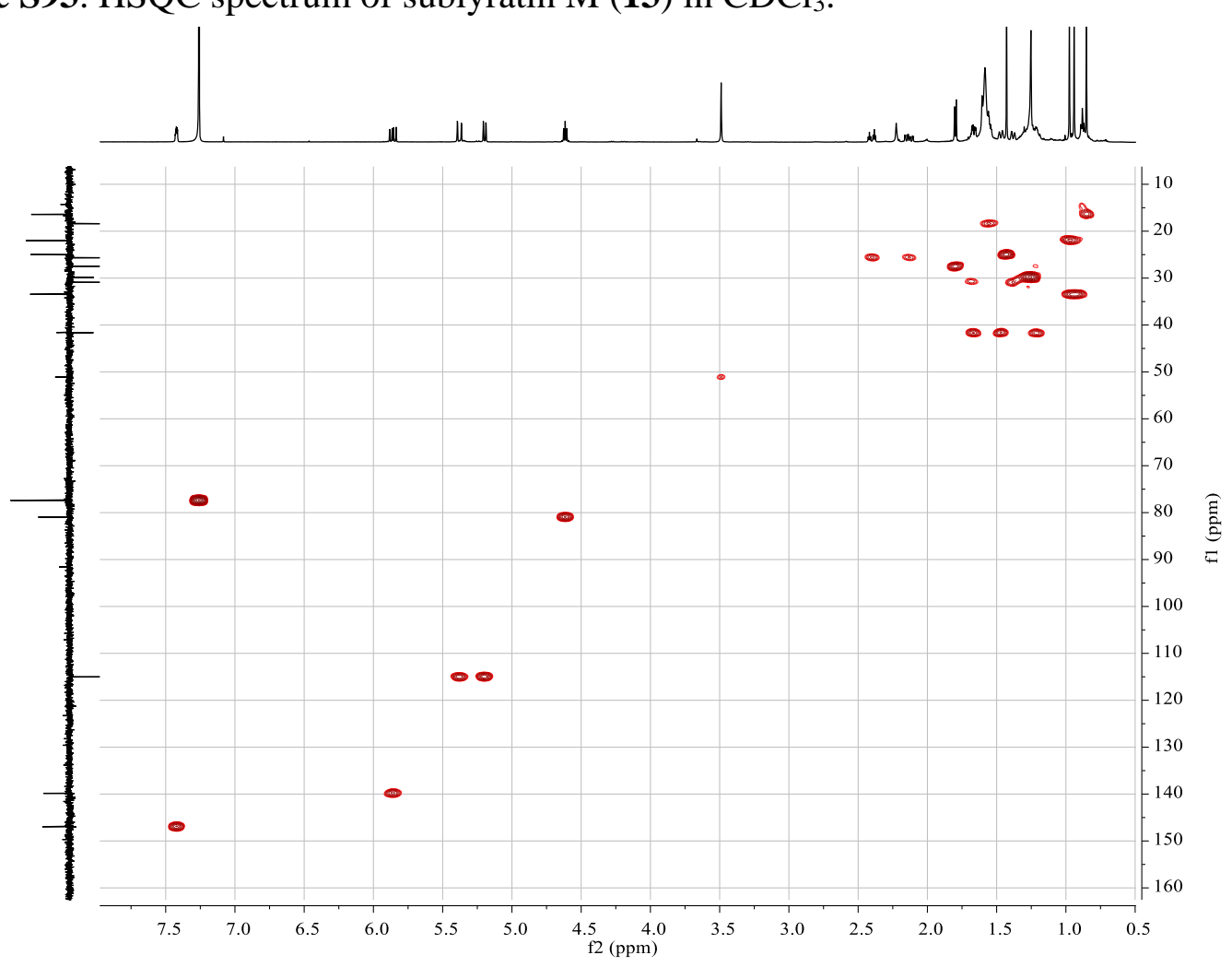

Figure S94. HMBC spectrum of sublyratin $\mathrm{M}(\mathbf{1 3})$ in $\mathrm{CDCl}_{3}$.

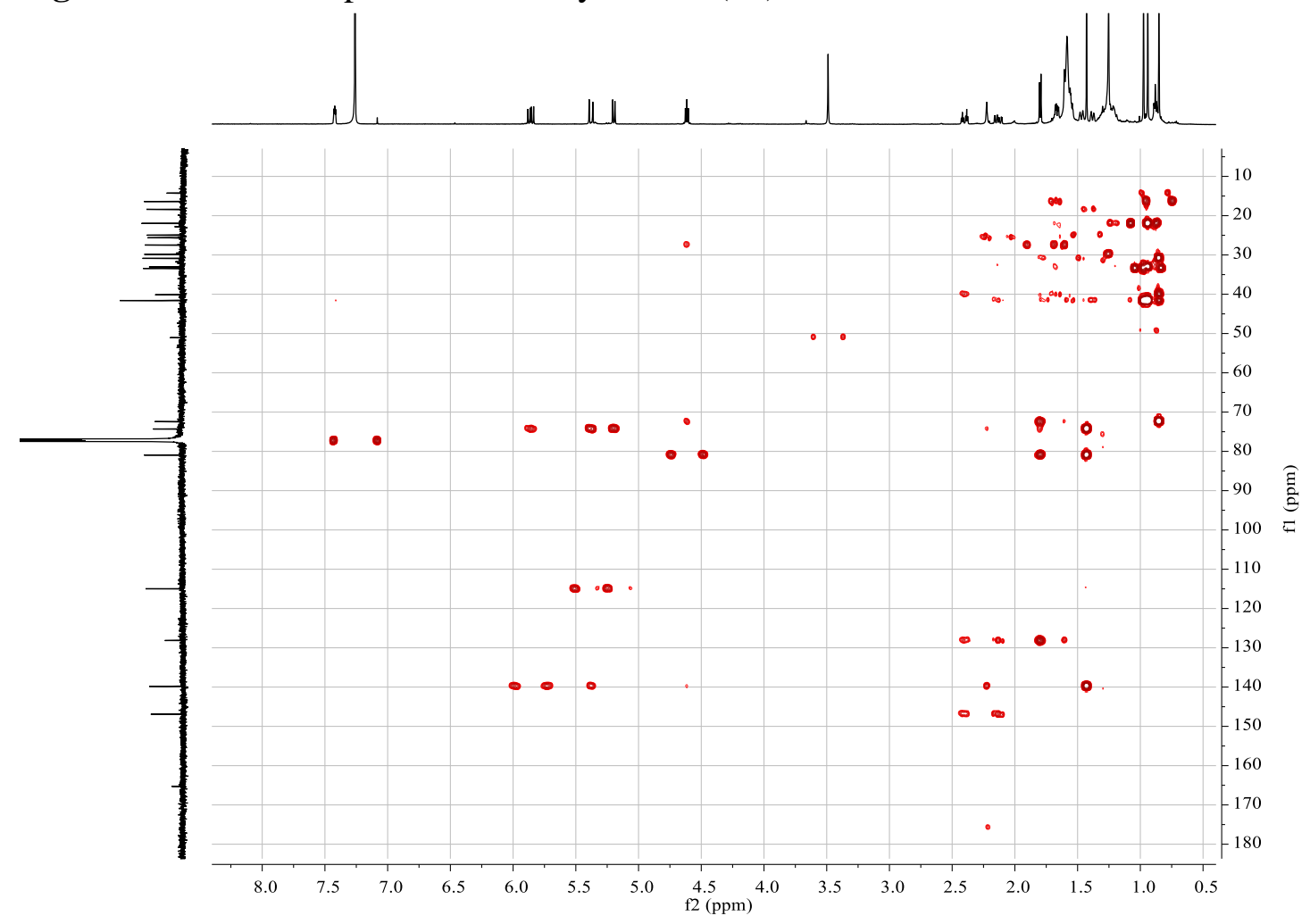

61 
Figure S95. ${ }^{1} \mathrm{H}-{ }^{1} \mathrm{H}$ COSY spectrum of sublyratin $\mathrm{M}(\mathbf{1 3})$ in $\mathrm{CDCl}_{3}$.

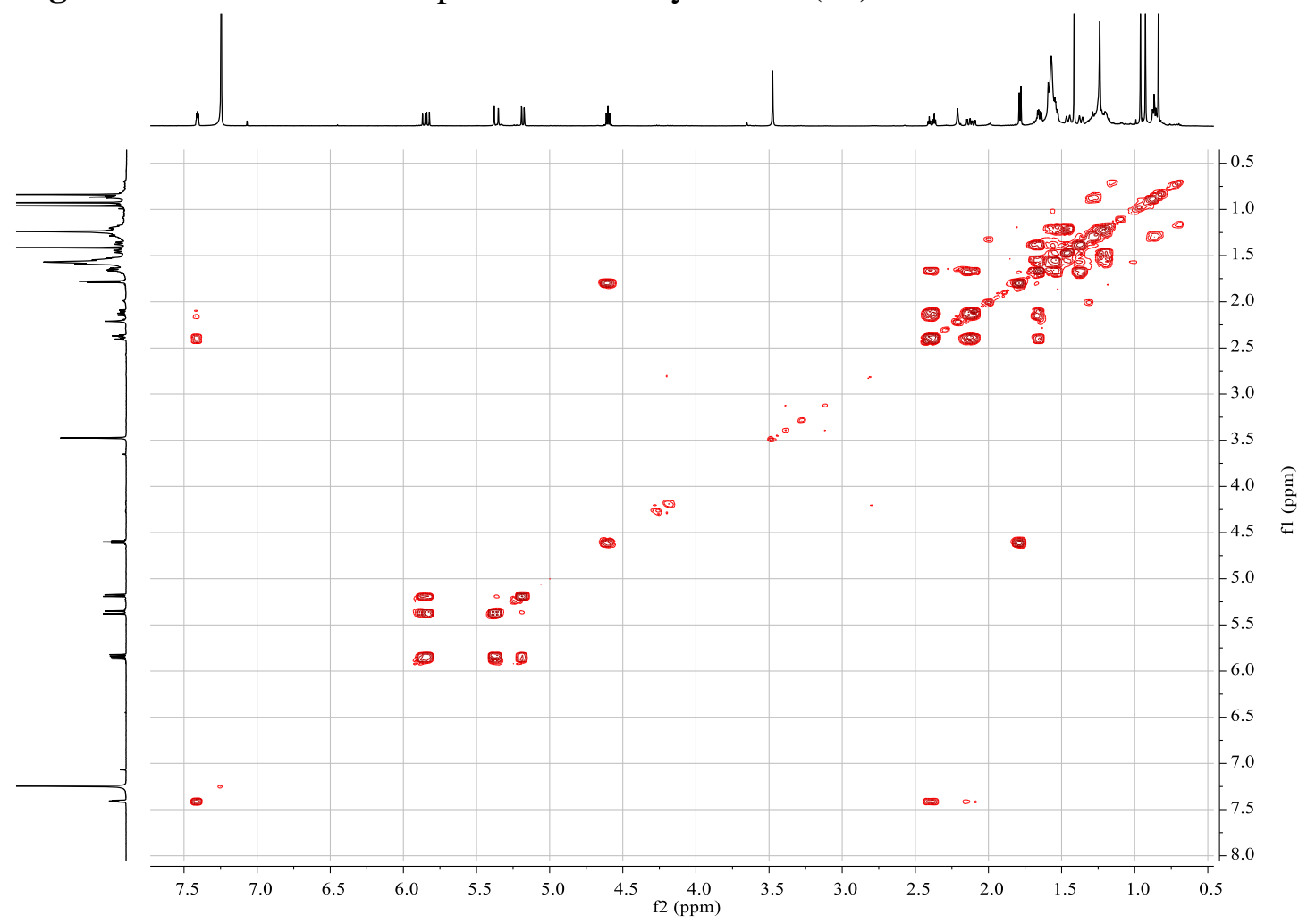

Figure S96. NOESY spectrum of sublyratin $\mathrm{M}(\mathbf{1 3})$ in $\mathrm{CDCl}_{3}$.

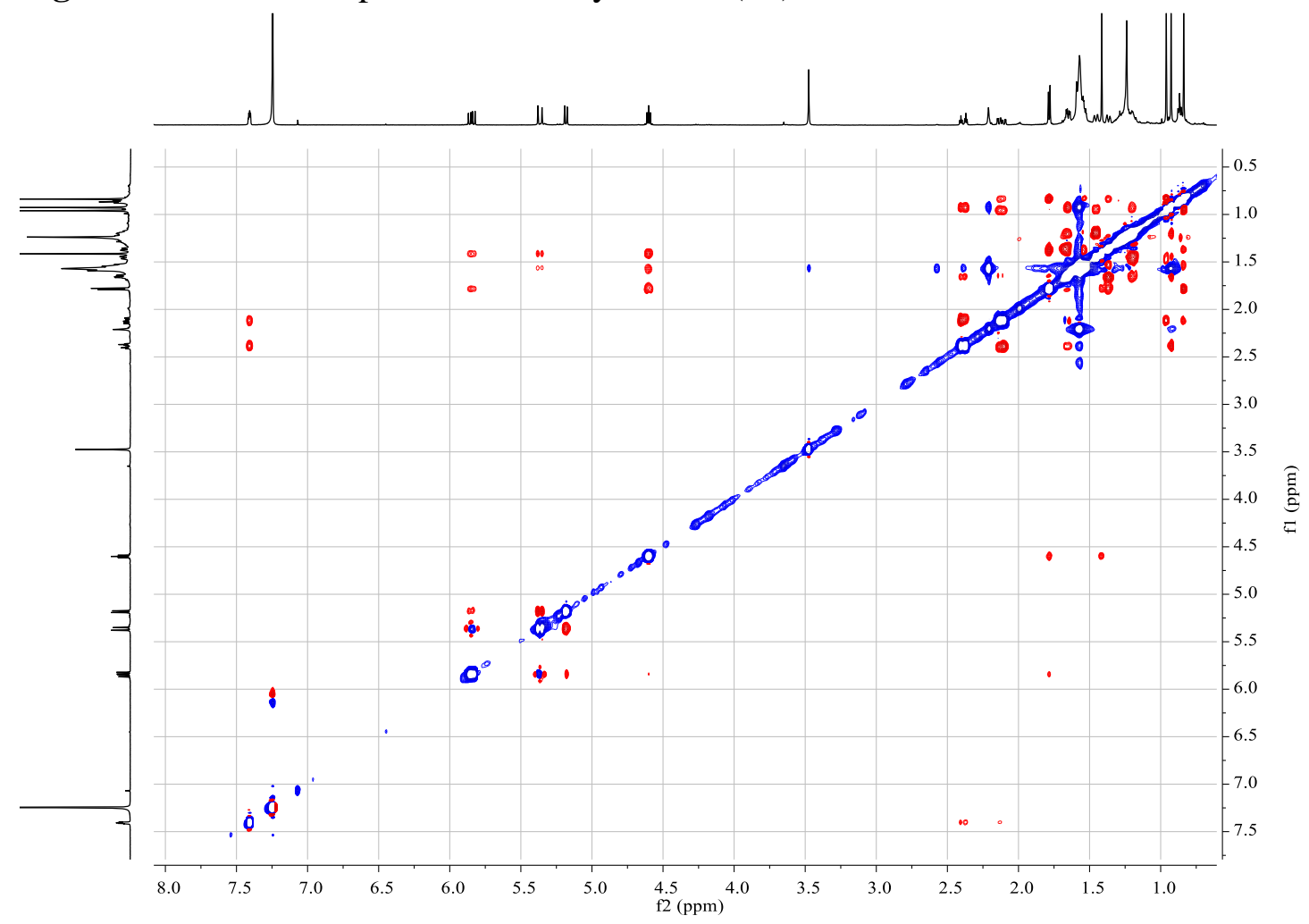


Figure S97. (+)-HRESIMS spectrum of sublyratin M (13).

Qualitative Analysis Report

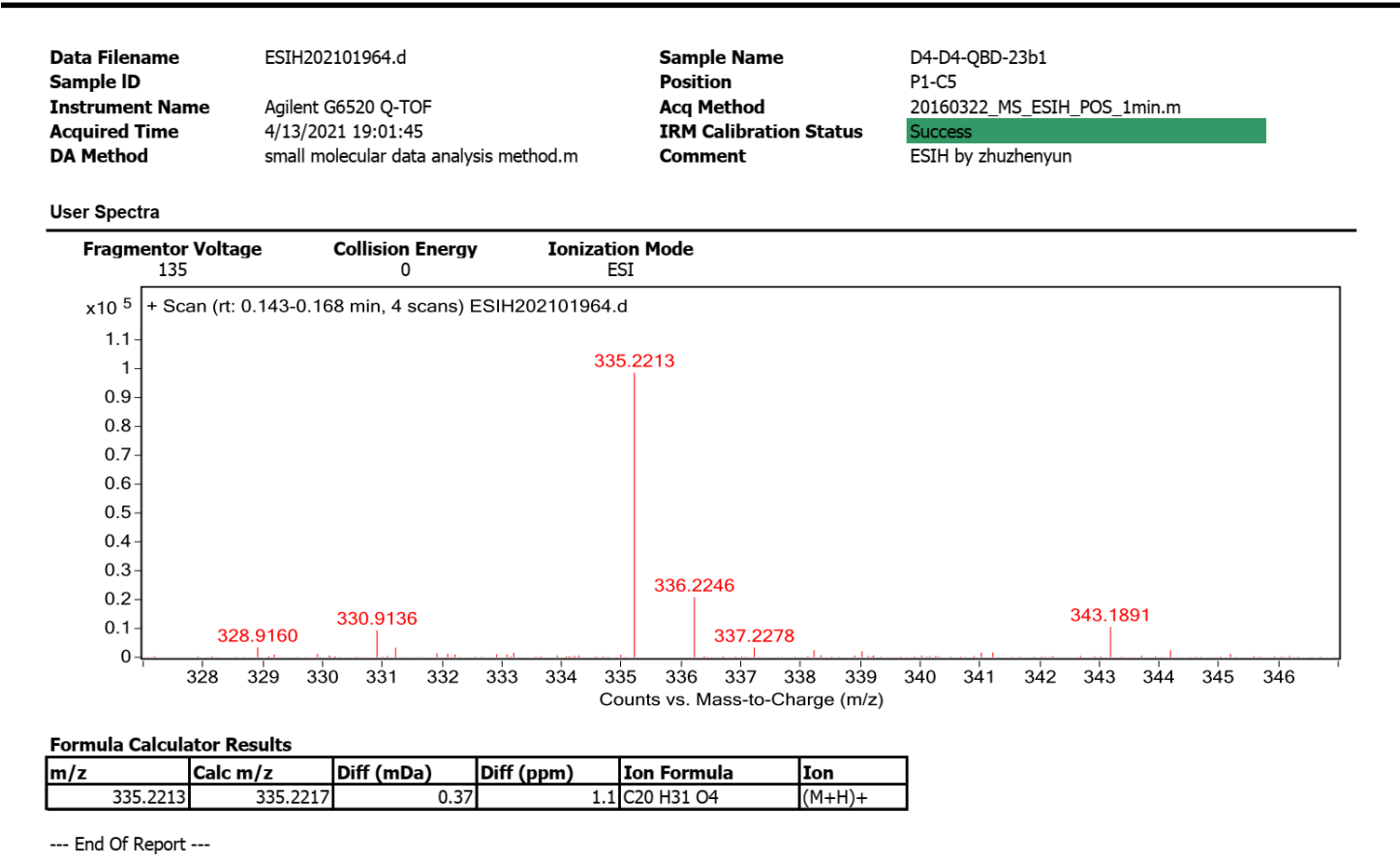


Figure S98. ${ }^{1} \mathrm{H}$ NMR spectrum of sublyratin $\mathrm{N}(\mathbf{1 4})$ in $\mathrm{CDCl}_{3}$.

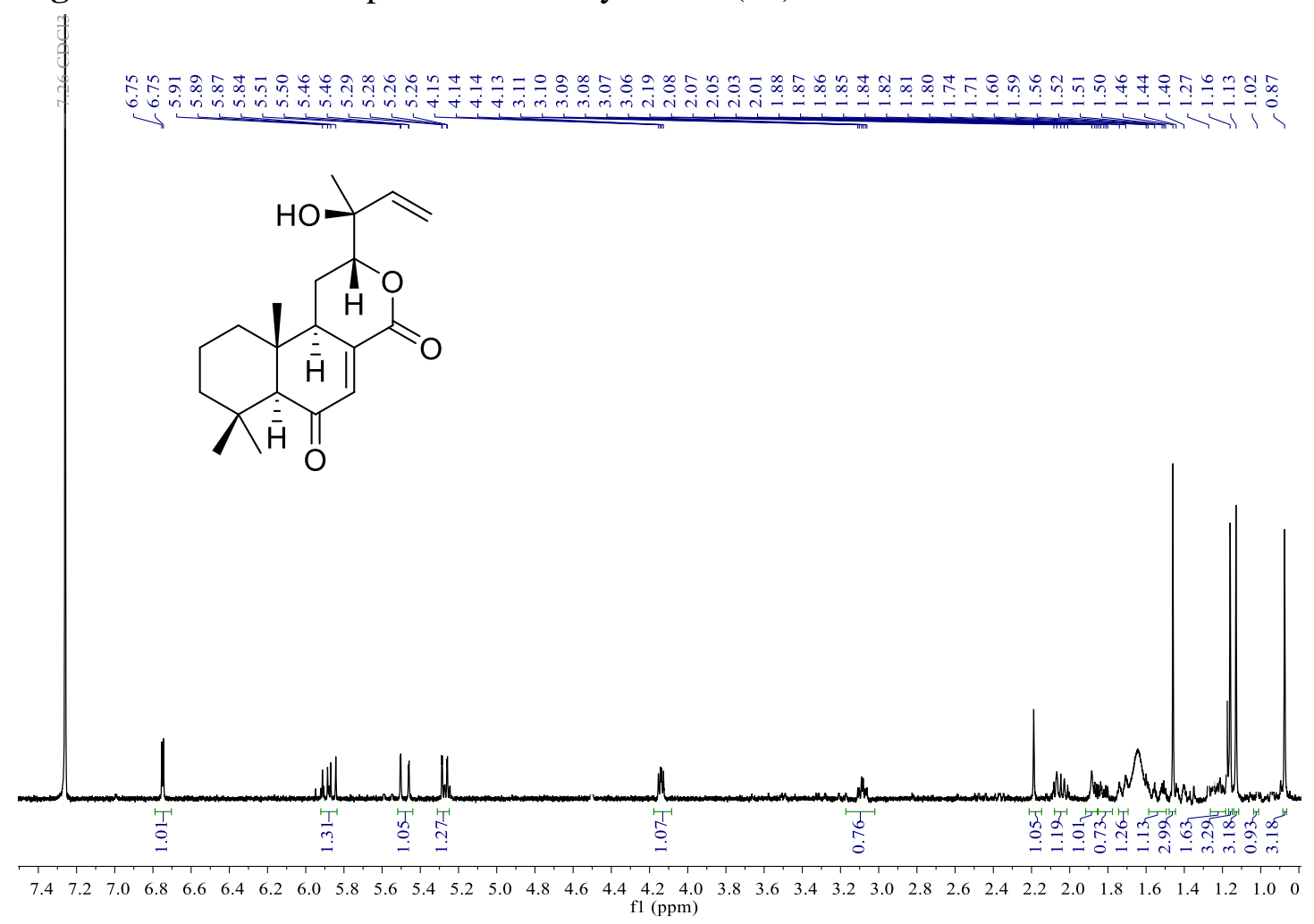

Figure S99. ${ }^{13} \mathrm{C}$ NMR spectrum of sublyratin $\mathrm{N}(\mathbf{1 4})$ in $\mathrm{CDCl}_{3}$.<smiles>C=CC(C)(O)C12CC3C(C=C(C)C31C)C(=O)OC2(C)C</smiles>

$\underset{\substack{\infty \\ \infty}}{\infty}$

章方章
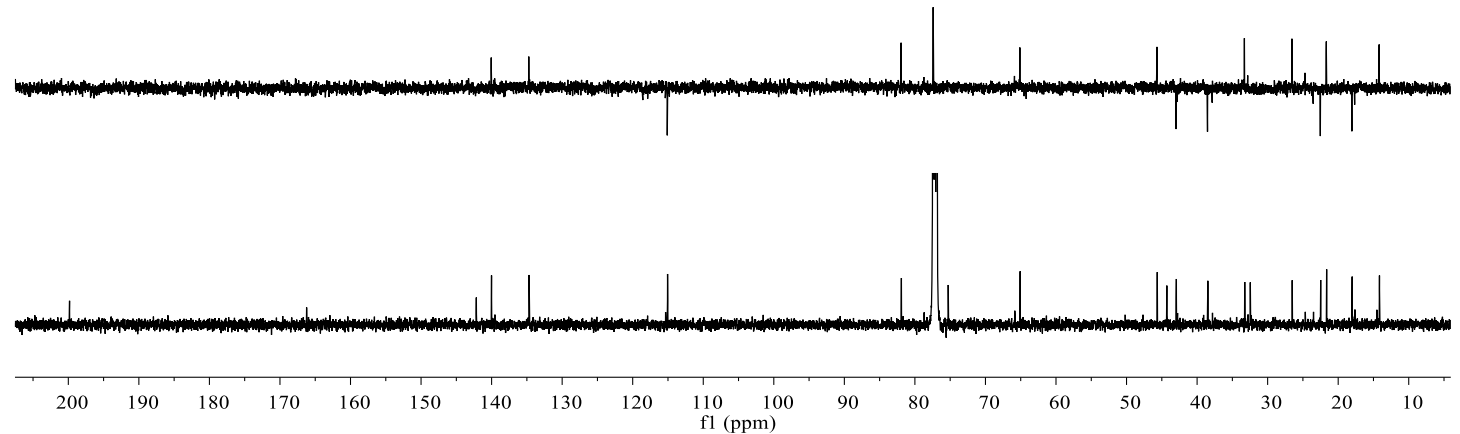
Figure S100. HSQC spectrum of sublyratin N (14) in $\mathrm{CDCl}_{3}$.

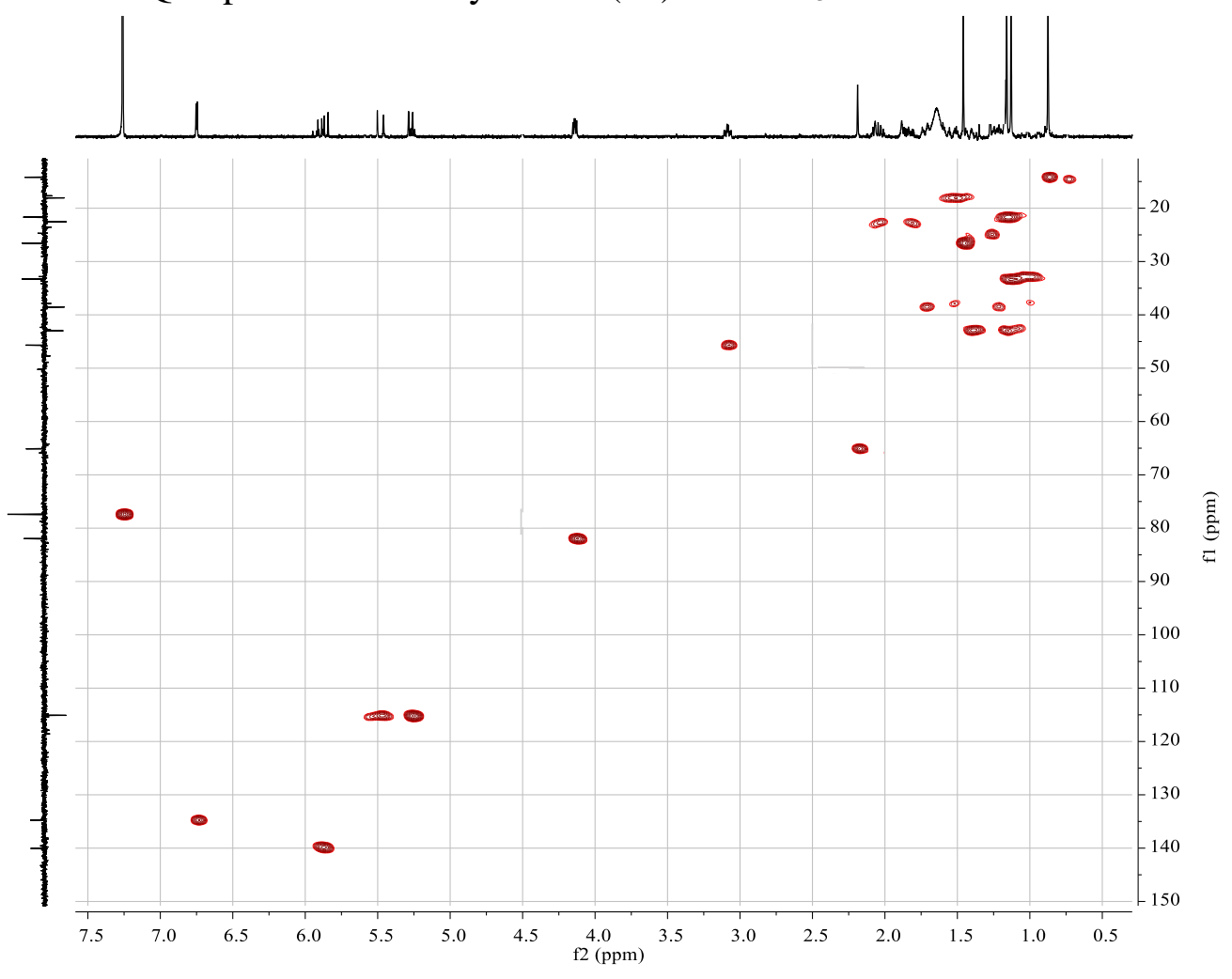

Figure S101. HMBC spectrum of sublyratin $\mathrm{N}(\mathbf{1 4})$ in $\mathrm{CDCl}_{3}$.

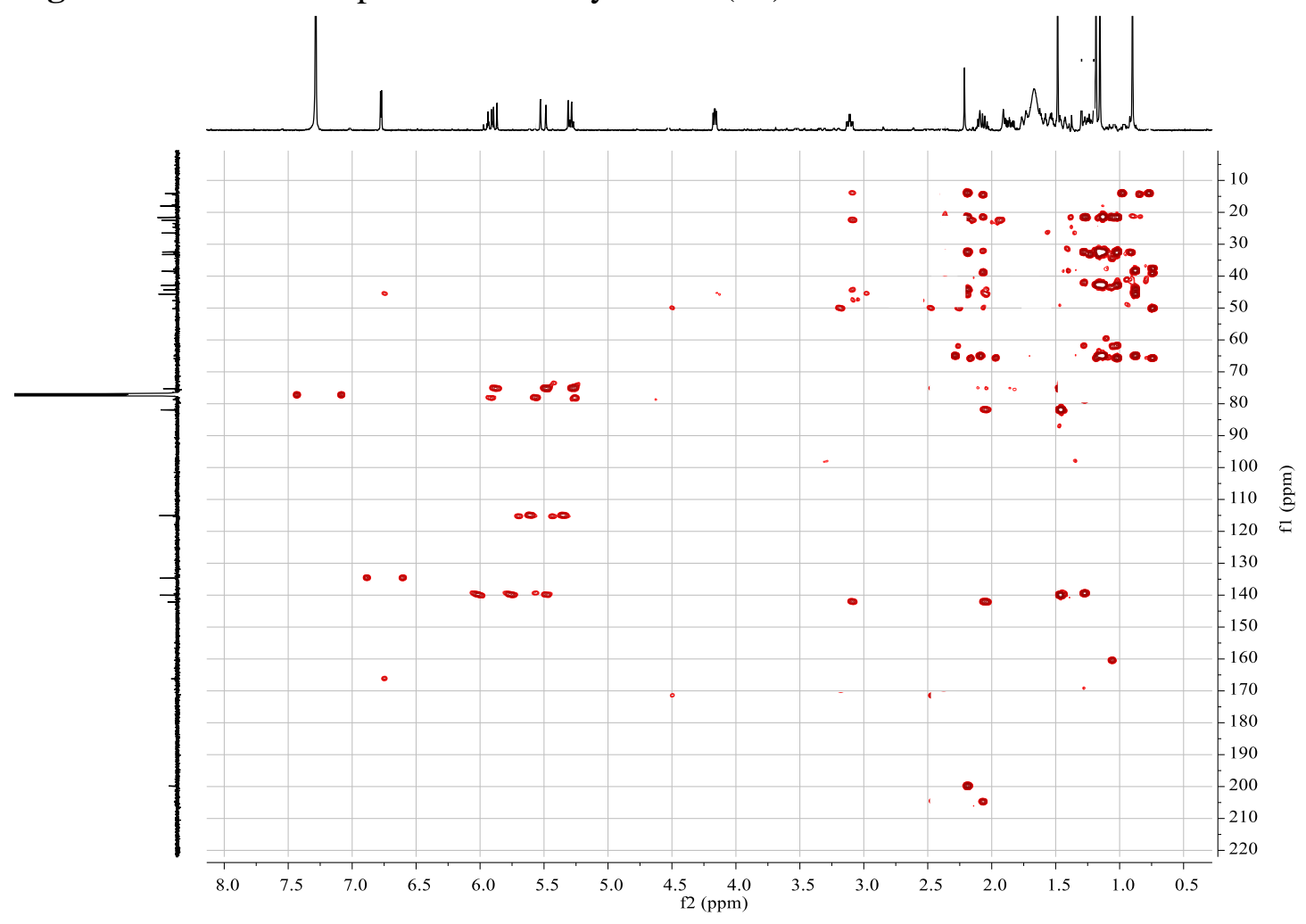


Figure S102. ${ }^{1} \mathrm{H}-{ }^{1} \mathrm{H}$ COSY spectrum of sublyratin $\mathrm{N}(\mathbf{1 4})$ in $\mathrm{CDCl}_{3}$.

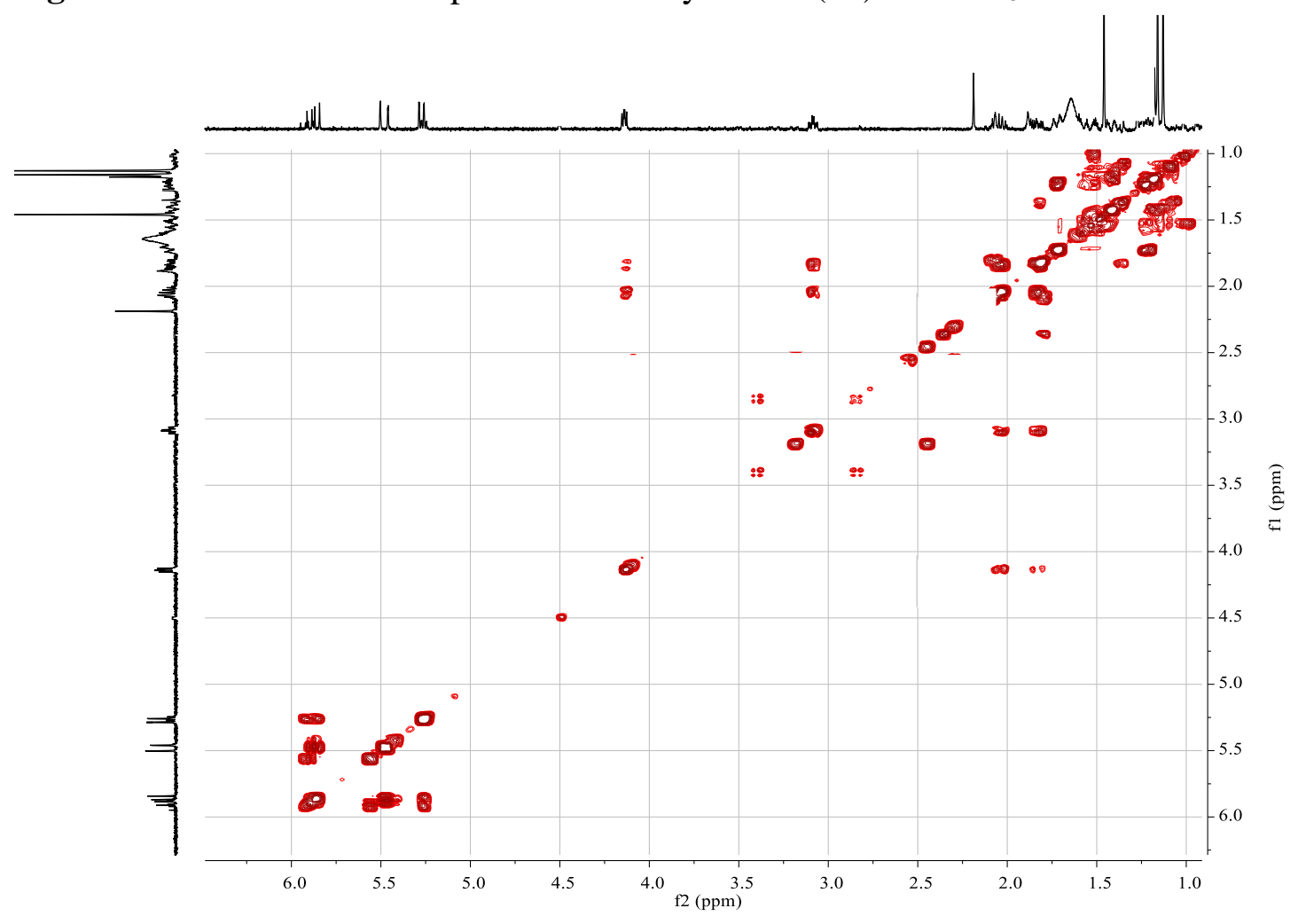

Figure S103. NOESY spectrum of sublyratin N (14) in $\mathrm{CDCl}_{3}$.

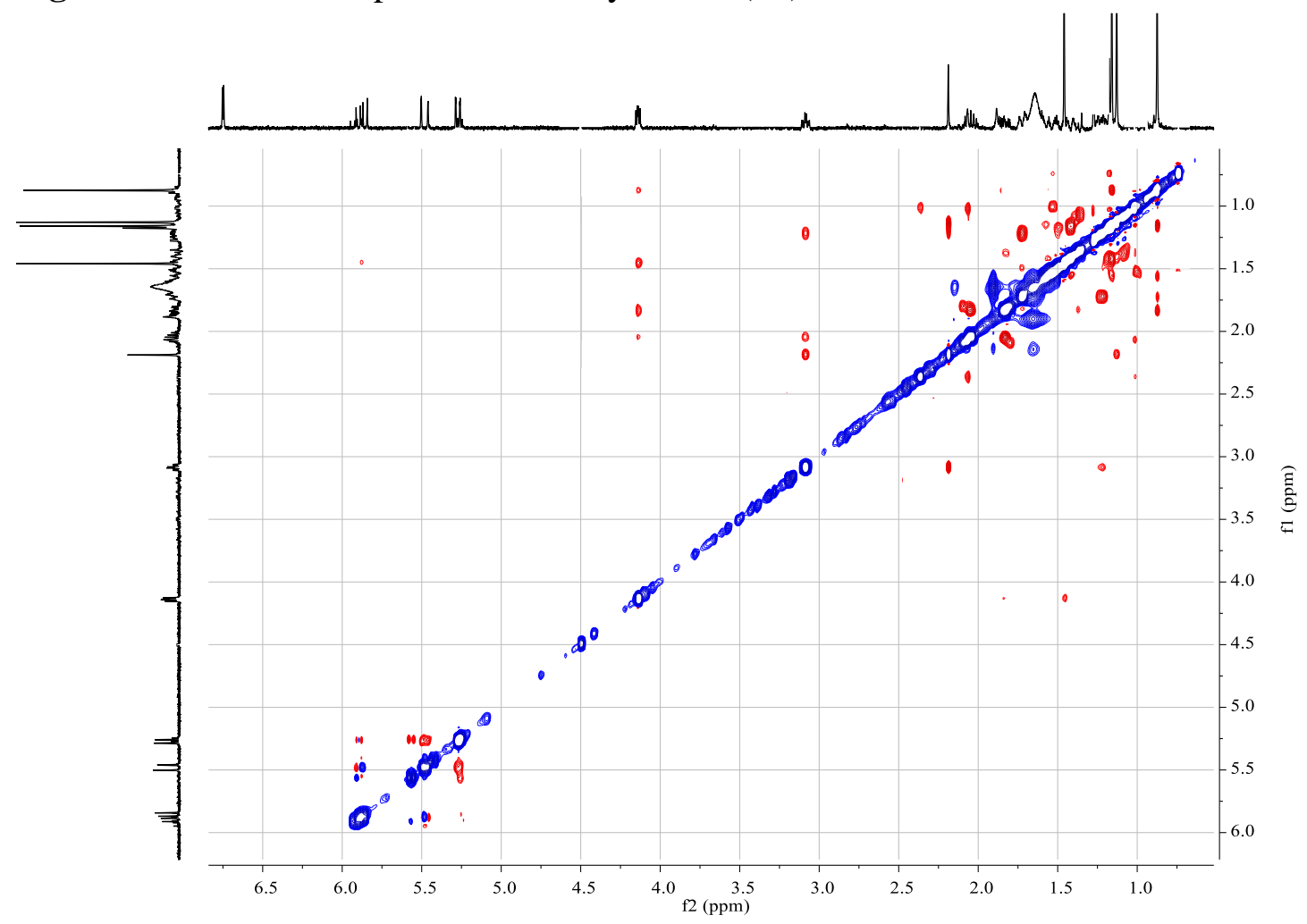


Figure S104. (+)-HRESIMS spectrum of sublyratin N (14).

Qualitative Analysis Report

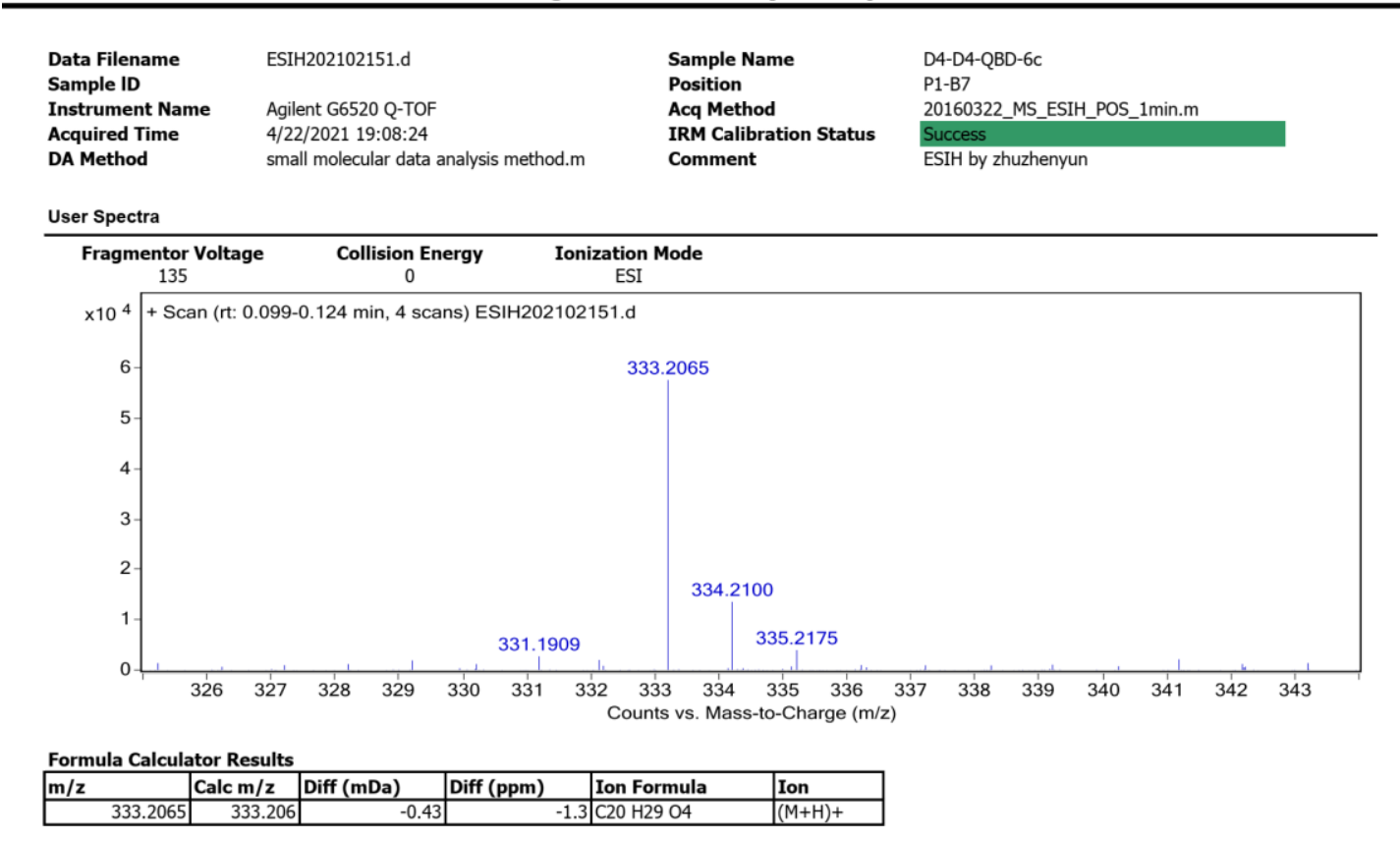

--- End Of Report --- 
Figure S105. ${ }^{1} \mathrm{H}$ NMR spectrum of sublyratin $\mathrm{O}(\mathbf{1 5})$ in $\mathrm{CDCl}_{3}$.

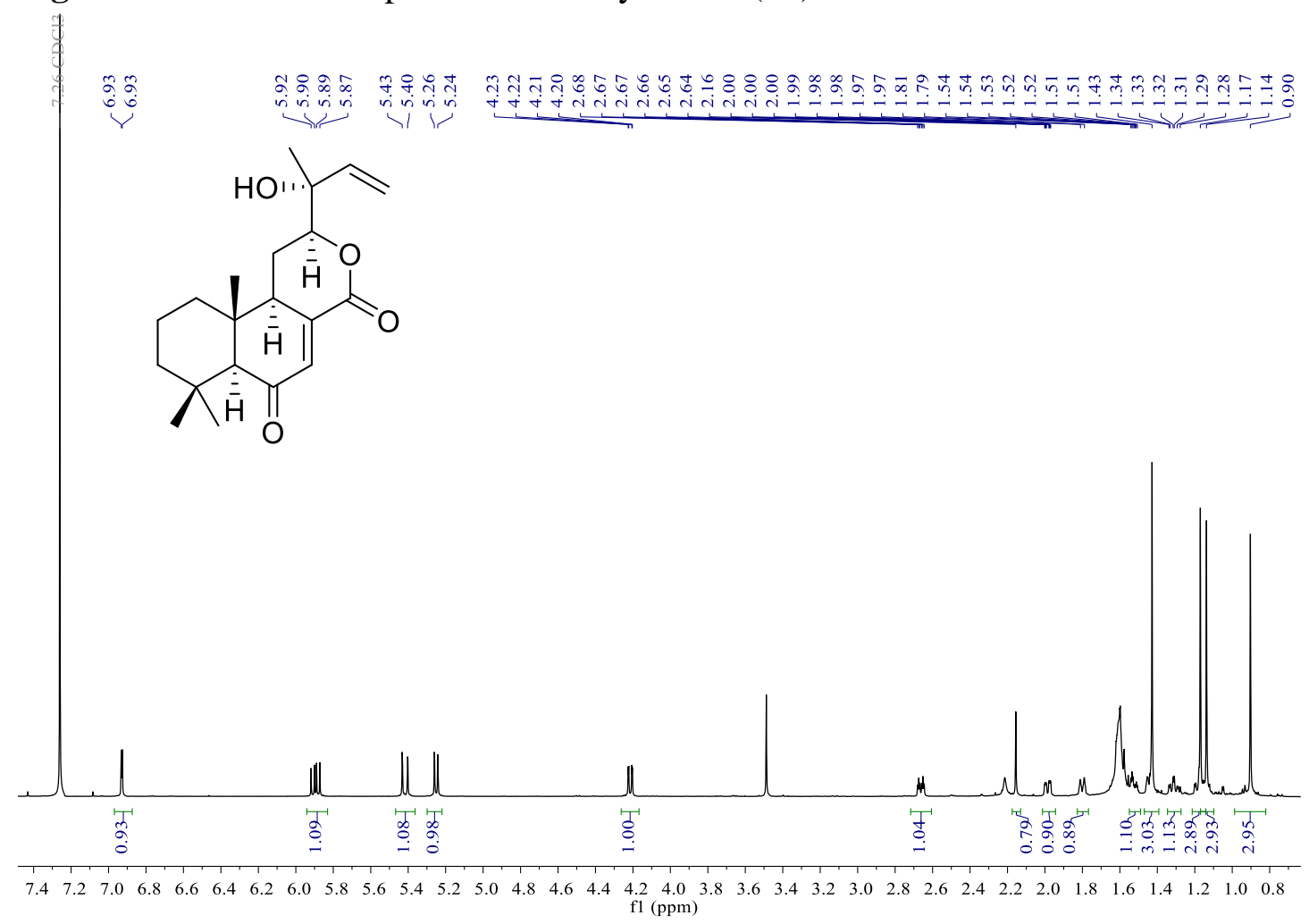

Figure S106. ${ }^{13} \mathrm{C}$ NMR spectrum of sublyratin $\mathrm{O}(\mathbf{1 5})$ in $\mathrm{CDCl}_{3}$.
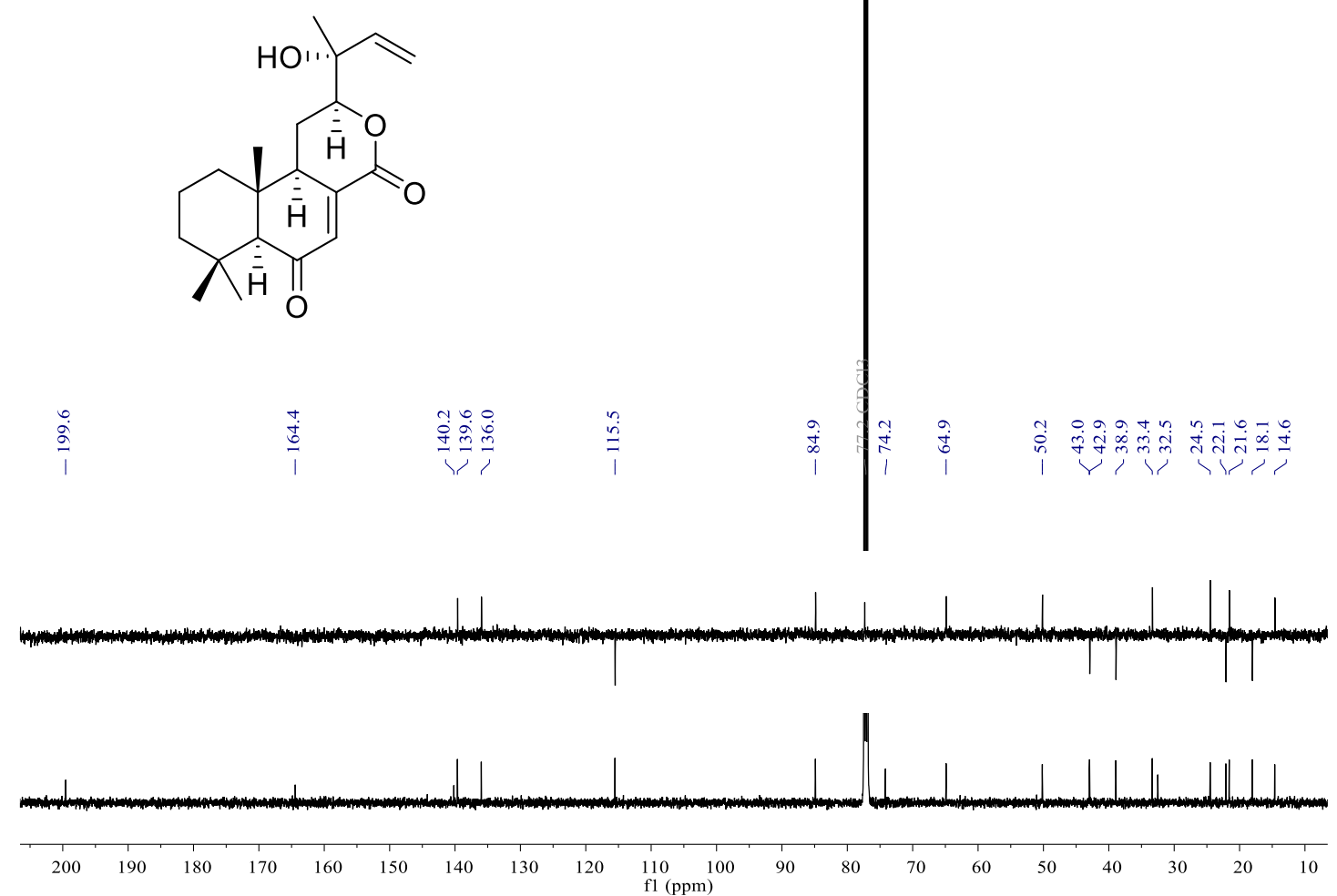
Figure S107. HSQC spectrum of sublyratin $\mathrm{O}(\mathbf{1 5})$ in $\mathrm{CDCl}_{3}$.

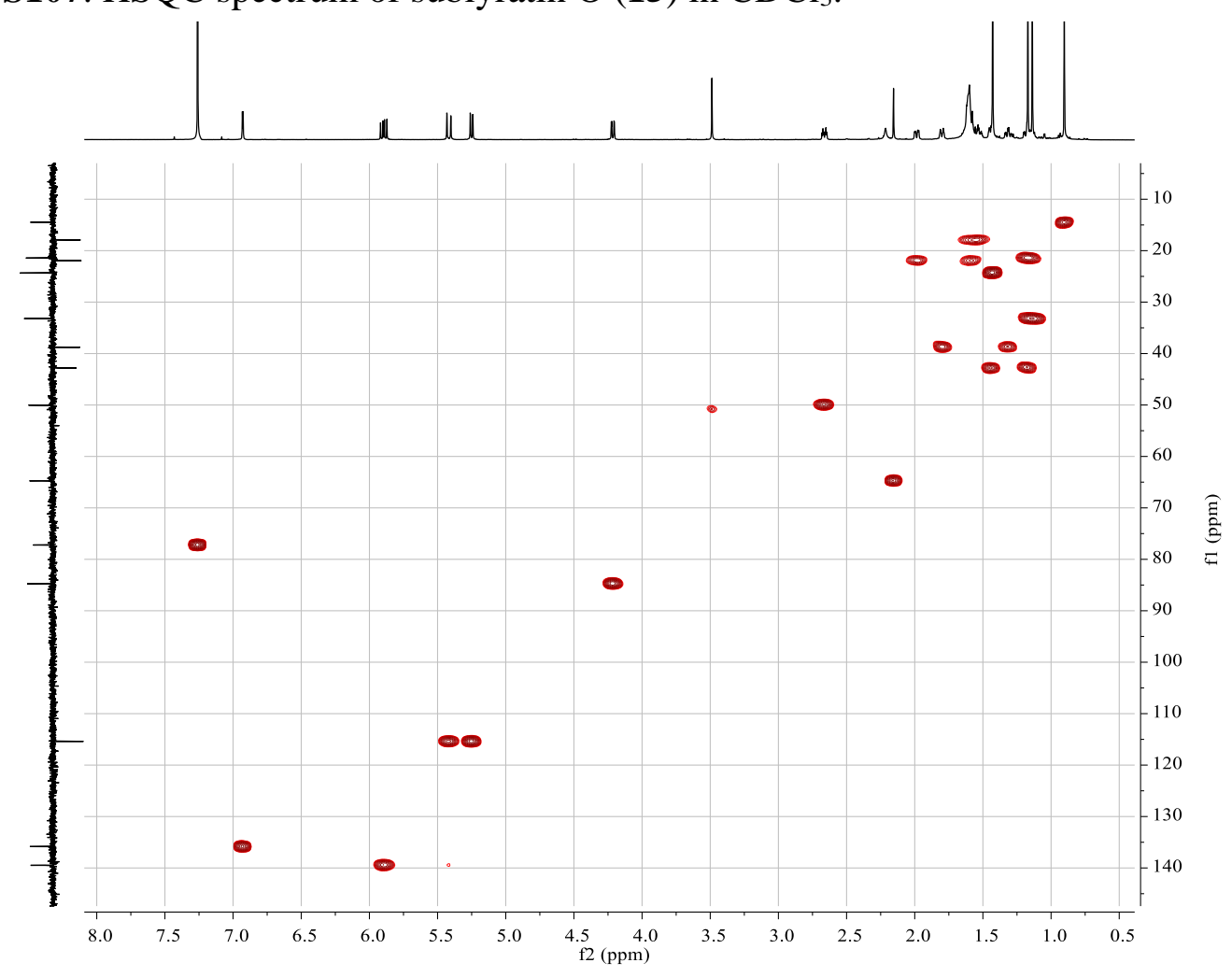

Figure S108. HMBC spectrum of sublyratin $\mathrm{O}(\mathbf{1 5})$ in $\mathrm{CDCl}_{3}$.

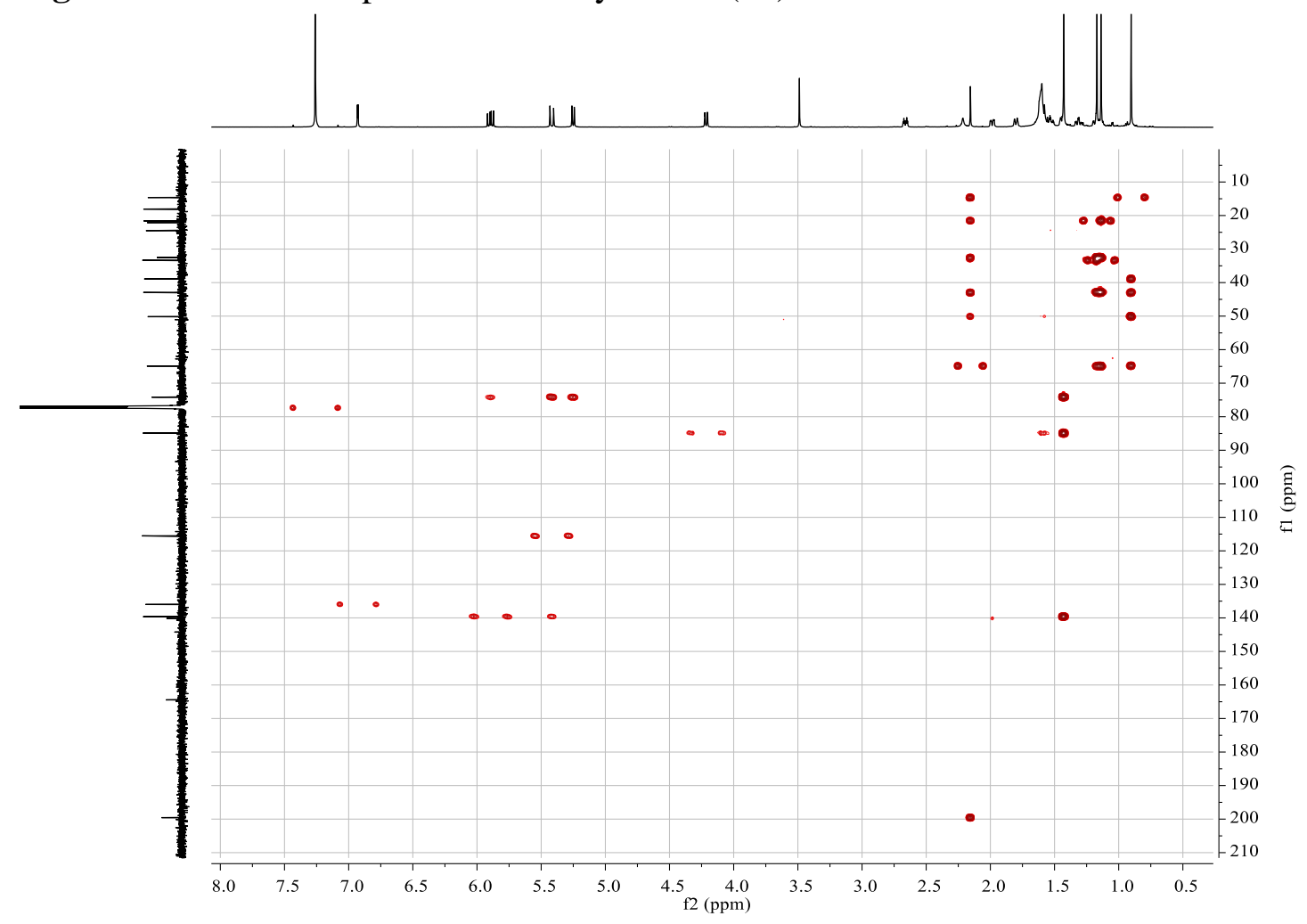

69 
Figure S109. ${ }^{1} \mathrm{H}-{ }^{1} \mathrm{H}$ COSY spectrum of sublyratin $\mathrm{O}(\mathbf{1 5})$ in $\mathrm{CDCl}_{3}$.

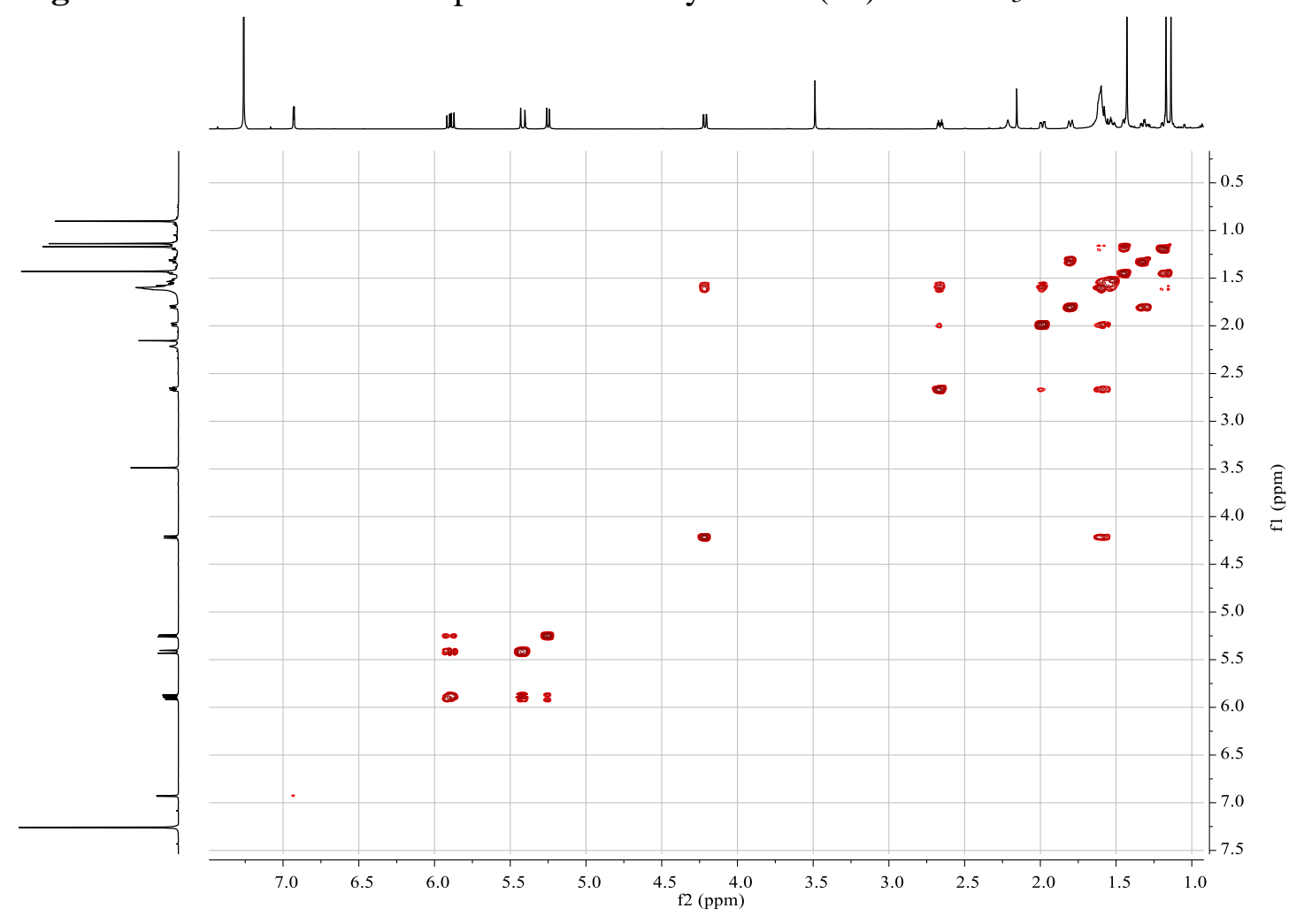

Figure S110. NOESY spectrum of sublyratin $\mathrm{O}(\mathbf{1 5})$ in $\mathrm{CDCl}_{3}$.

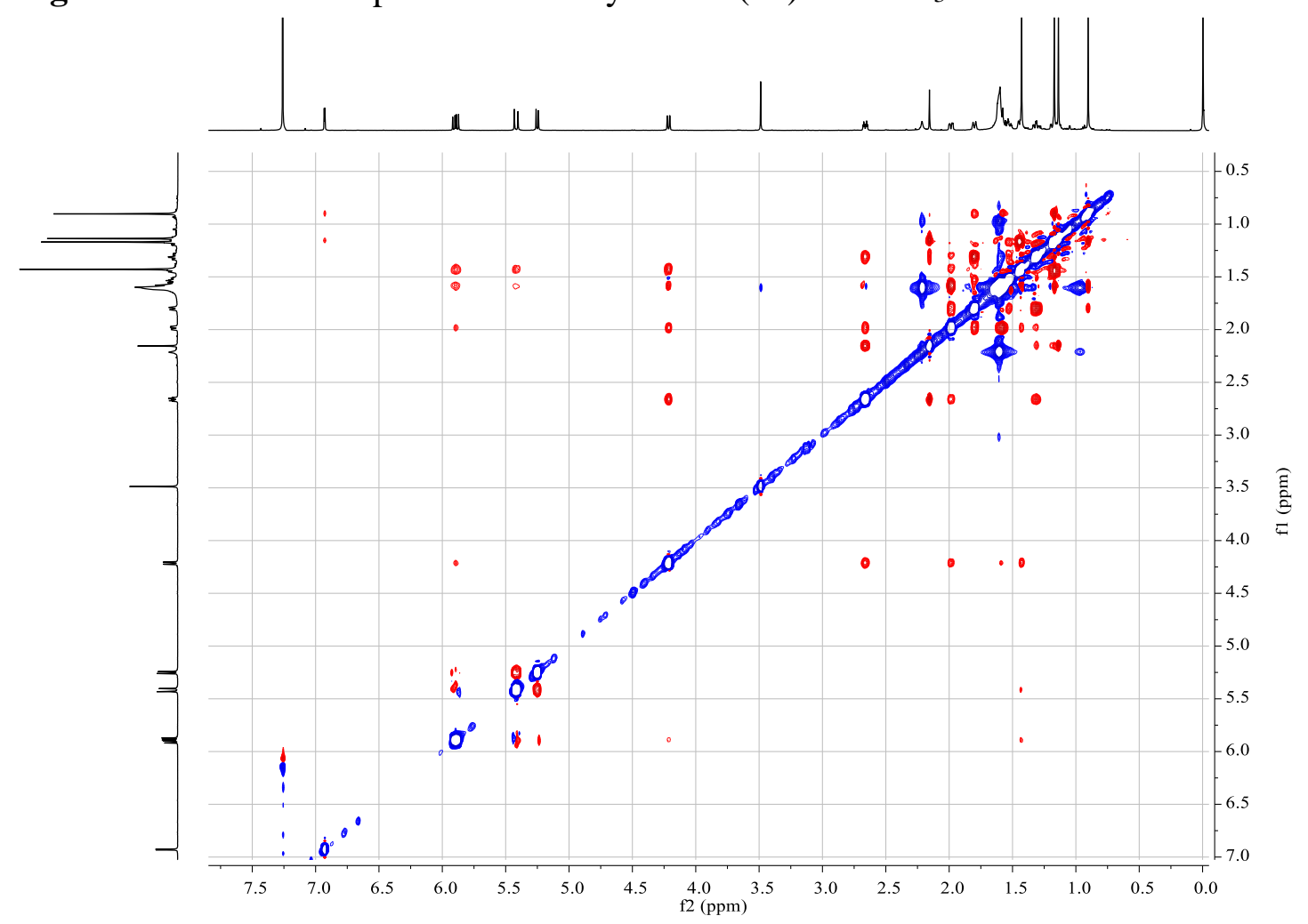


Figure S111. (-)-HRESIMS spectrum of sublyratin O (15).

Qualitative Analysis Report

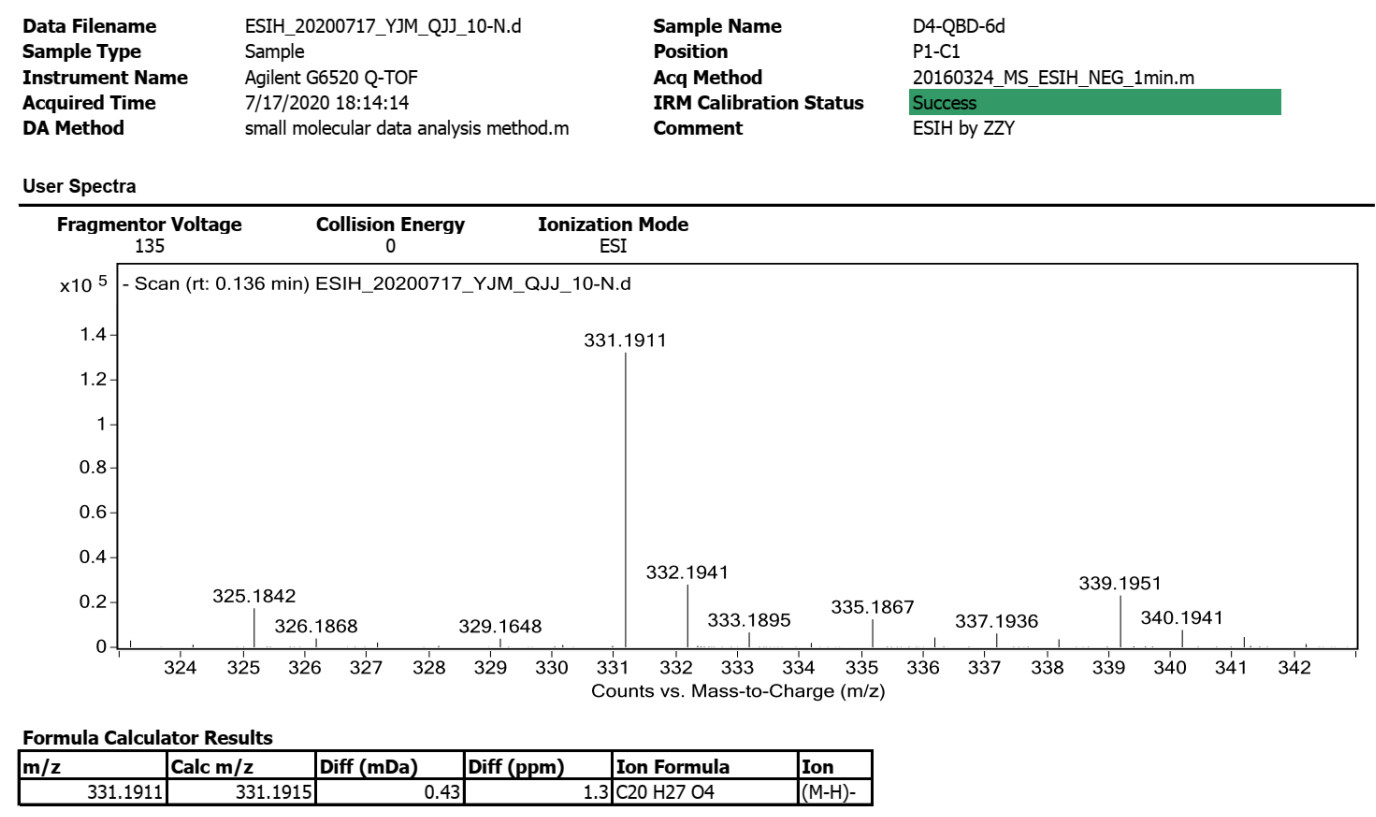

--- End Of Report --- 